\title{
Discovery and Total Synthesis of a Bis(Cyclotryptamine)
} Alkaloid Bearing the Elusive Piperidinoindoline Scaffold

\author{
Jordan J. Dotson, J. Logan Bachman, \\ Miguel A. Garcia-Garibay,* and Neil K. Garg* \\ Department of Chemistry and Biochemistry, University of California, \\ Los Angeles, California 90095 \\ Supporting Information - Table of Contents
}

Materials and Methods.

Experimental Procedures

${ }^{1}$ H NMR Spectra

${ }^{13} \mathrm{C}$ NMR Spectra .$S 45$

Alternative Routes Explored .560

Alternative Mechanism for the Conversion of 22 to 25 .563

X-Ray Crystal Structure Data. .564

References .572 
Materials and methods. Unless stated otherwise, reactions were conducted in flame-dried glassware under an atmosphere of nitrogen using anhydrous solvents (either freshly distilled or passed through activated alumina columns). All commercially available reagents were used as received unless otherwise specified. Tetrapropylammonium perruthenate (TPAP), trifluoroacetic acid, $N$-methylmorpholine $N$-oxide, 4-dimethylaminopyridine, sodium hydride ( $60 \%$ dispersion in mineral oil), oxalyl chloride, iodomethane (MeI), bromoacetonitrile, iodomethane, lithium bis(trimethylsilyl)amide (LiHMDS), ceric ammonium nitrate, copper(I) iodide, sodium azide, Lproline, and sodium borohydride were obtained from Sigma-Aldrich. Cobalt(II) chloride hexahydrate and 4-methoxybenzyl chloride were purchased from TCI America. $\mathrm{CH}_{2} \mathrm{Cl}_{2}$ saturated with $\mathrm{NH}_{3}$ was prepared by sparging a glass bottle of $\mathrm{CH}_{2} \mathrm{Cl}_{2}$ with gaseous $\mathrm{NH}_{3}$ for 10 minutes. Unless stated otherwise, reactions were performed at room temperature (rt, approximately $23^{\circ} \mathrm{C}$ ). Thin-layer chromatography (TLC) was conducted with EMD gel 60 F254 pre-coated plates $(0.25$ $\mathrm{mm}$ ) and visualized using a combination of UV, ceric ammonium molybdate, and potassium permanganate staining. Silicycle silica gel 60 (particle size $0.040-0.063 \mathrm{~mm}$ ) was used for flash column chromatography. Compounds 18 and 19 were purified using a Teledyne ISCO CombiFlash $^{\circledR}$ NextGen $^{\mathrm{TM}}$ instrument using RediSep ${ }^{\circledR} \mathrm{Rf}$ high-performance silica gold columns (24 g, catalog No. 692203346, 12 g, catalog No. 692203345). ${ }^{1} \mathrm{H}$ NMR spectra were recorded on Bruker spectrometers (at $300 \mathrm{MHz}, 500 \mathrm{MHz}$, or $600 \mathrm{MHz}$ ) and are reported relative to deuterated solvent signals. Data for ${ }^{1} \mathrm{H}$ NMR spectra are reported as follows: chemical shift ( $\left.\delta \mathrm{ppm}\right)$, multiplicity, coupling constant $(\mathrm{Hz})$ and integration. ${ }^{13} \mathrm{C}$ NMR spectra are reported in terms of chemical shift (at $125 \mathrm{MHz}$ ). High-resolution mass spectra were obtained on Thermo Scientific ${ }^{\mathrm{TM}}$ Exactive Mass Spectrometers with DART ID-CUBE. X-ray structures shown in Figure 2 and Schemes 2 and 3 of the manuscript were created using CYLview. 


\section{Experimental Procedures.}
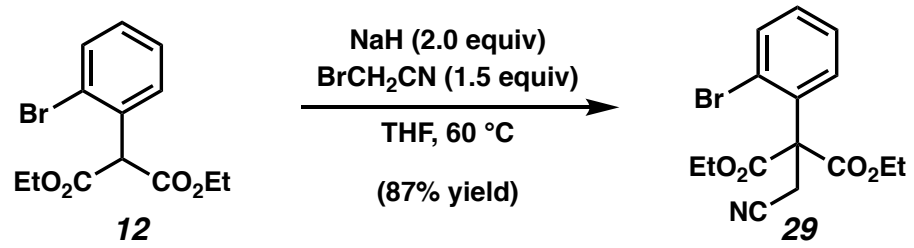

Nitrile 29. To a solution of malonate ester $\mathbf{1 2}^{1}$ (42.0 g, $136 \mathrm{mmol}, 1.00$ equiv) in THF (330 mL), was added $\mathrm{NaH}$ (10.7 g, 60\% dispersion in mineral oil, $268 \mathrm{mmol}, 1.97$ equiv) in 3 portions over $10 \mathrm{~min}$ with stirring. Bromoacetonitrile (13.9 mL, $14.2 \mathrm{~g}, 204 \mathrm{mmol}, 1.50$ equiv) was added dropwise via syringe over 1 minute. The reaction was submerged in an oil bath preheated to $60{ }^{\circ} \mathrm{C}$ and stirred for $15 \mathrm{~h}$. Then the reaction was cooled to $23^{\circ} \mathrm{C}$ and poured into a biphasic mixture of sat. aq. $\mathrm{NH}_{4} \mathrm{Cl}(500 \mathrm{~mL})$ and $\mathrm{CH}_{2} \mathrm{Cl}_{2}(500 \mathrm{~mL})$. The layers were separated and the aqueous layer was extracted with $\mathrm{CH}_{2} \mathrm{Cl}_{2}(2 \times 200 \mathrm{~mL})$. The combined organic layers were dried over $\mathrm{Na}_{2} \mathrm{SO}_{4}$ and concentrated directly onto silica gel $(120 \mathrm{~g})$ under reduced pressure. The crude product was purified by flash column chromatography (120 g silica gel, 9:1 Hexanes:EtOAc $\rightarrow$ 7:3 Hexanes:EtOAc) to yield 29 as a white solid (40.9 g, 87\% yield). Nitrile 29: mp: $84.7-85.6{ }^{\circ} \mathrm{C}, \mathrm{R}_{\mathrm{f}}$ 0.42 (7:3 Hexanes:EtOAc); ${ }^{1} \mathrm{H}$ NMR $\left(300 \mathrm{MHz}, \mathrm{CDCl}_{3}\right) \delta 7.63(\mathrm{dd}, J=7.9,1.4 \mathrm{~Hz}, 1 \mathrm{H}), 7.37$ (td, $J=7.6,1.4 \mathrm{~Hz}, 1 \mathrm{H}), 7.25(\mathrm{td}, J=7.7,1.7 \mathrm{~Hz}, 1 \mathrm{H}), 7.17(\mathrm{dd}, J=7.8,1.7 \mathrm{~Hz}, 1 \mathrm{H}), 4.48-4.17(\mathrm{~m}$, 4H), $3.53(\mathrm{~s}, 2 \mathrm{H}), 1.32(\mathrm{t}, J=7.1 \mathrm{~Hz}, 6 \mathrm{H}) ;{ }^{13} \mathrm{C} \mathrm{NMR}\left(125 \mathrm{MHz}, \mathrm{CDCl}_{3}\right) \delta 167.8,135.1,135.0$, 130.6, 130.4, 128.1, 122.9, 116.9, 63.5, 63.1, 24.0, 13.9; HRMS-APCI (m/z) $[\mathrm{M}+\mathrm{H}]^{+}$calcd for $\mathrm{C}_{15} \mathrm{H}_{17} \mathrm{NO}_{4} \mathrm{Br}^{+}, 354.0341$; found 354.0337. 


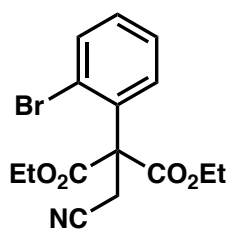

29

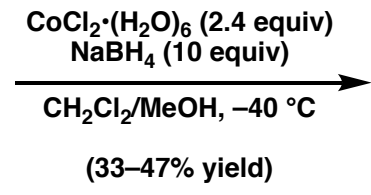

(33-47\% yield)

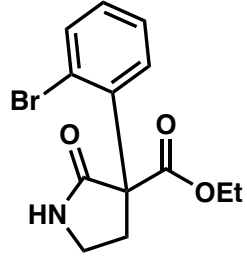

13

Pyrrolidinone 13. Nitrile 29 (20.6 g, $58.2 \mathrm{mmol}$, 1.00 equiv) was split into two reactions which were run in parallel as follows: To a solution of nitrile 29 (10.3 g, $29.1 \mathrm{mmol}, 1.00 \mathrm{equiv})$ in $\mathrm{CH}_{2} \mathrm{Cl}_{2}(50 \mathrm{~mL})$ was added $\mathrm{MeOH}(320 \mathrm{~mL})$ followed by $\mathrm{CoCl}_{2} \cdot\left(\mathrm{H}_{2} \mathrm{O}\right)_{6}(16.3 \mathrm{~g}, 68.5 \mathrm{mmol}, 2.35$ equiv) and the solution was then cooled to $-40{ }^{\circ} \mathrm{C}$. $\mathrm{NaBH}_{4}(10.7 \mathrm{~g}, 282 \mathrm{mmol}, 9.69$ equiv) was added in small aliquots $(\sim 300 \mathrm{mg})$ every 1 minute for the course of 36 minutes. Following this addition, aq. $\mathrm{HCl}(3.0 \mathrm{M}, 200 \mathrm{~mL})$ was added and the resultant mixture was stirred for 5 minutes. Sat. aq. $\mathrm{NH}_{4} \mathrm{OH}(250 \mathrm{~mL})$ was then added and the reaction was stirred for another 25 minutes. The two parallel reactions were combined and poured into a biphasic mixture of sat. aq. $\mathrm{NaCl}(200$ $\mathrm{mL})$ and EtOAc $(500 \mathrm{~mL})$. The layers were separated, and the aqueous layer was extracted with EtOAc $(2 \times 200 \mathrm{~mL})$. The combined organic layers were diluted with $\mathrm{CH}_{2} \mathrm{Cl}_{2}(500 \mathrm{~mL})$, dried over $\mathrm{Na}_{2} \mathrm{SO}_{4}$, and concentrated under reduced pressure. The crude oil was dissolved in EtOAc (10 mL), seeded with a small amount of crystalline pyrrolidinone 13, and allowed to recrystallize overnight. The crystalline solid was rinsed with $0{ }^{\circ} \mathrm{C}$ EtOAc $(\sim 10 \mathrm{~mL})$ to furnish pyrrolidinone $\mathbf{1 3}$ as a white solid (6.76 g, 38\% yield). Note that the yield of 13 ranges from 33-47\%. Pyrrolidinone 13: mp: 127.2-127.6 ${ }^{\circ} \mathrm{C} ; \mathrm{R}_{\mathrm{f}} 0.43$ (2:8 Hexanes:EtOAc); ${ }^{1} \mathrm{H}$ NMR $\left(500 \mathrm{MHz}, \mathrm{CDCl}_{3}\right) \delta 7.75(\mathrm{~s}, 1 \mathrm{H}), 7.59$ $(\mathrm{dd}, J=7.9,1.3 \mathrm{~Hz}, 1 \mathrm{H}), 7.46(\mathrm{dd}, J=7.9,1.7 \mathrm{~Hz}, 1 \mathrm{H}), 7.31(\mathrm{td}, J=7.6,1.4 \mathrm{~Hz}, 1 \mathrm{H}), 7.16(\mathrm{td}, J$ $=7.7,1.6 \mathrm{~Hz}, 1 \mathrm{H}), 4.29(\mathrm{dq}, J=10.8,7.1 \mathrm{~Hz}, 1 \mathrm{H}), 4.22(\mathrm{dq}, J=10.8,7.1 \mathrm{~Hz}, 1 \mathrm{H}), 3.54-3.42(\mathrm{~m}$, 2H), $3.27-3.13(\mathrm{~m}, 1 \mathrm{H}), 2.47-2.31(\mathrm{~m}, 1 \mathrm{H}), 1.24(\mathrm{t}, J=7.1 \mathrm{~Hz}, 3 \mathrm{H}) ;{ }^{13} \mathrm{C} \mathrm{NMR}(125 \mathrm{MHz}$, 
$\left.\mathrm{CDCl}_{3}\right) \delta 174.1,170.2,138.5,134.2,129.2,129.0,127.7,124.0,62.7,62.6,39.4,33.7,13.9$ HRMS-APCI $(\mathrm{m} / \mathrm{z})[\mathrm{M}+\mathrm{H}]^{+}$calcd for $\mathrm{C}_{13} \mathrm{H}_{15} \mathrm{NO}_{3} \mathrm{Br}^{+}, 312.0235$; found 312.0223 .

Note 1: It is critical to maintain rapid stirring and efficient cooling for the duration of this reaction to mitigate the formation of side products (reduction of the $\mathrm{C}-\mathrm{Br}$ to $\mathrm{C}-\mathrm{H}$ ). For this reason, reactions on $>10 \mathrm{~g}$ scale were run in parallel and combined for workup and purification. The remaining over-reduced product is cleanly removed during the recrystallization.

Note 2: It is critical that $\mathrm{NaBH}_{4}$ is added slowly, the reaction vigorously releases $\mathrm{H}_{2}$ gas.
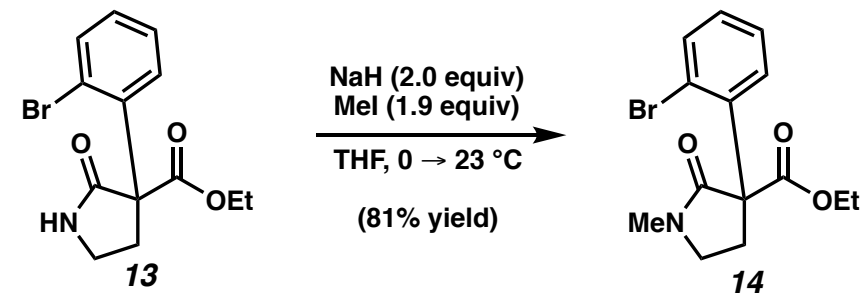

Pyrrolidinone 14. To a solution of pyrrolidinone 13 ( $1.50 \mathrm{~g}, 4.81 \mathrm{mmol}, 1.00$ equiv) in THF (50 $\mathrm{mL})$, was added $\mathrm{NaH}(0.390 \mathrm{~g}, 60 \%$ dispersion in mineral oil, $9.75 \mathrm{mmol}, 2.03$ equiv). The reaction mixture was stirred at $23{ }^{\circ} \mathrm{C}$ for 10 minutes before it was cooled to $0{ }^{\circ} \mathrm{C}$. MeI $(0.450 \mathrm{~mL}, 1.30 \mathrm{~g}$, 9.16 mmol, 1.91 equiv) was added dropwise over 2 minutes and the reaction was stirred for a further 15 minutes at this temperature. The ice bath was removed, and the reaction was stirred for 25 minutes at $23{ }^{\circ} \mathrm{C}$. The reaction was then poured into a biphasic mixture of sat. aq. $\mathrm{NH}_{4} \mathrm{Cl}(100$ $\mathrm{mL})$ and $\mathrm{CH}_{2} \mathrm{Cl}_{2}(200 \mathrm{~mL})$. The layers were separated, and the aqueous layer was extracted with $\mathrm{CH}_{2} \mathrm{Cl}_{2}(2 \times 50 \mathrm{~mL})$. The combined organic layers were dried over $\mathrm{MgSO}_{4}$ before being concentrated under reduced pressure directly onto silica gel $(2.5 \mathrm{~g})$. The crude product was purified by flash column chromatography ( $8 \mathrm{~g}$ silica gel, 7:3 Hexanes:EtOAc $\rightarrow$ 1:1 Hexanes:EtOAc) to give pyrrolidinone 14 (1.27 g, 81\% yield) as a white solid. Pyrrolidinone 14: mp: $121.1-121.6{ }^{\circ} \mathrm{C}$; $\mathrm{R}_{\mathrm{f}} 0.44\left(3: 7\right.$ Hexanes:EtOAc); ${ }^{1} \mathrm{H}$ NMR (300 MHz, CDCl3) $\delta 7.59(\mathrm{dd}, J=7.9,1.3 \mathrm{~Hz}, 1 \mathrm{H}), 7.34$ 
$-7.25(\mathrm{~m}, 2 \mathrm{H}), 7.15(\mathrm{td}, J=7.6,1.9 \mathrm{~Hz}, 1 \mathrm{H}), 4.39-4.11(\mathrm{~m}, 2 \mathrm{H}), 3.65-3.35(\mathrm{~m}, 2 \mathrm{H}), 3.35-$ $3.19(\mathrm{~m}, 1 \mathrm{H}), 3.00(\mathrm{~s}, 3 \mathrm{H}), 2.33-2.15(\mathrm{~m}, 1 \mathrm{H}), 1.24(\mathrm{t}, J=7.1 \mathrm{~Hz}, 3 \mathrm{H}) ;{ }^{13} \mathrm{C}$ NMR $(125 \mathrm{MHz}$, $\left.\mathrm{CDCl}_{3}\right) \delta 174.5,170.3,138.6,134.3,129.3,129.1,127.8,124.1,63.0,62.7,62.2,39.6,33.8,14.0$ HRMS-APCI (m/z) [M + H] calcd for $\mathrm{C}_{14} \mathrm{H}_{17} \mathrm{NO}_{3} \mathrm{Br}^{+}$, 326.0392; found 326.0384 .
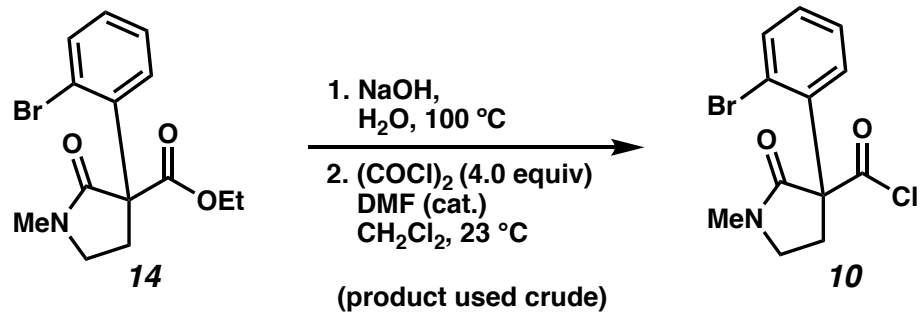

Acid Chloride 10. A suspension of pyrrolidinone 14 (0.830 g, $2.54 \mathrm{mmol}, 1.00$ equiv) in aq. $\mathrm{NaOH}$ (1.0 M, $15 \mathrm{~mL}$ ) was heated at reflux until the solution became homogeneous ( $5 \mathrm{~min})$ and then was allowed to cool to $23{ }^{\circ} \mathrm{C}$. The reaction was poured into aq. $\mathrm{HCl}(0.5 \mathrm{M}, 50 \mathrm{~mL})$ and the aqueous layer was extracted with $\mathrm{CH}_{2} \mathrm{Cl}_{2}(3 \times 100 \mathrm{~mL})$. The combined organic layers were dried over $\mathrm{MgSO}_{4}$ and concentrated under reduced pressure. The resultant crude carboxylic acid was carried directly to the next step.

To a solution of the crude carboxylic acid in $\mathrm{CH}_{2} \mathrm{Cl}_{2}(20 \mathrm{~mL})$ with two drops of DMF from a glass Pasteur pipette, oxalyl chloride $(0.870 \mathrm{~mL}, 10.1 \mathrm{mmol}, 3.98$ equiv) was added dropwise over 1 minute. The reaction was stirred for $1 \mathrm{~h}$ at $23{ }^{\circ} \mathrm{C}$ before being concentrated under reduced pressure. The resultant oil was dissolved in $\mathrm{PhMe}(20 \mathrm{~mL})$ and concentrated under reduced pressure (x2). The crude oil was then put under vacuum ( $<1$ mbar) for $1 \mathrm{~h}$. Crude acid chloride $\mathbf{1 0}$ was used immediately without further purification.

Note 1: It is critical that this set-up is kept anhydrous and excess oxalyl chloride is fully removed at the end of the reaction. Each time the acid chloride was concentrated under rotary evaporation 
(both from $\mathrm{CH}_{2} \mathrm{Cl}_{2}$ and then from $\mathrm{PhMe}$ ) the water bath was maintained at $50{ }^{\circ} \mathrm{C}$ and the vacuum was maintained at the highest setting ( 15 mbar) for 15 minutes. The oil was left under high vacuum $(<1$ mbar) for $1 \mathrm{~h}$ to ensure complete removal of the oxalyl chloride.

Note 2: The carboxylic acid does not completely dissolve in $\mathrm{CH}_{2} \mathrm{Cl}_{2}$. Once the oxalyl chloride has been added all of the solids dissolve within 30 minutes.

Note 3: In order to ensure water is not introduced between rotary evaporations, the rotary evaporator is backfilled with a balloon of dry Ar for this step (see image below).
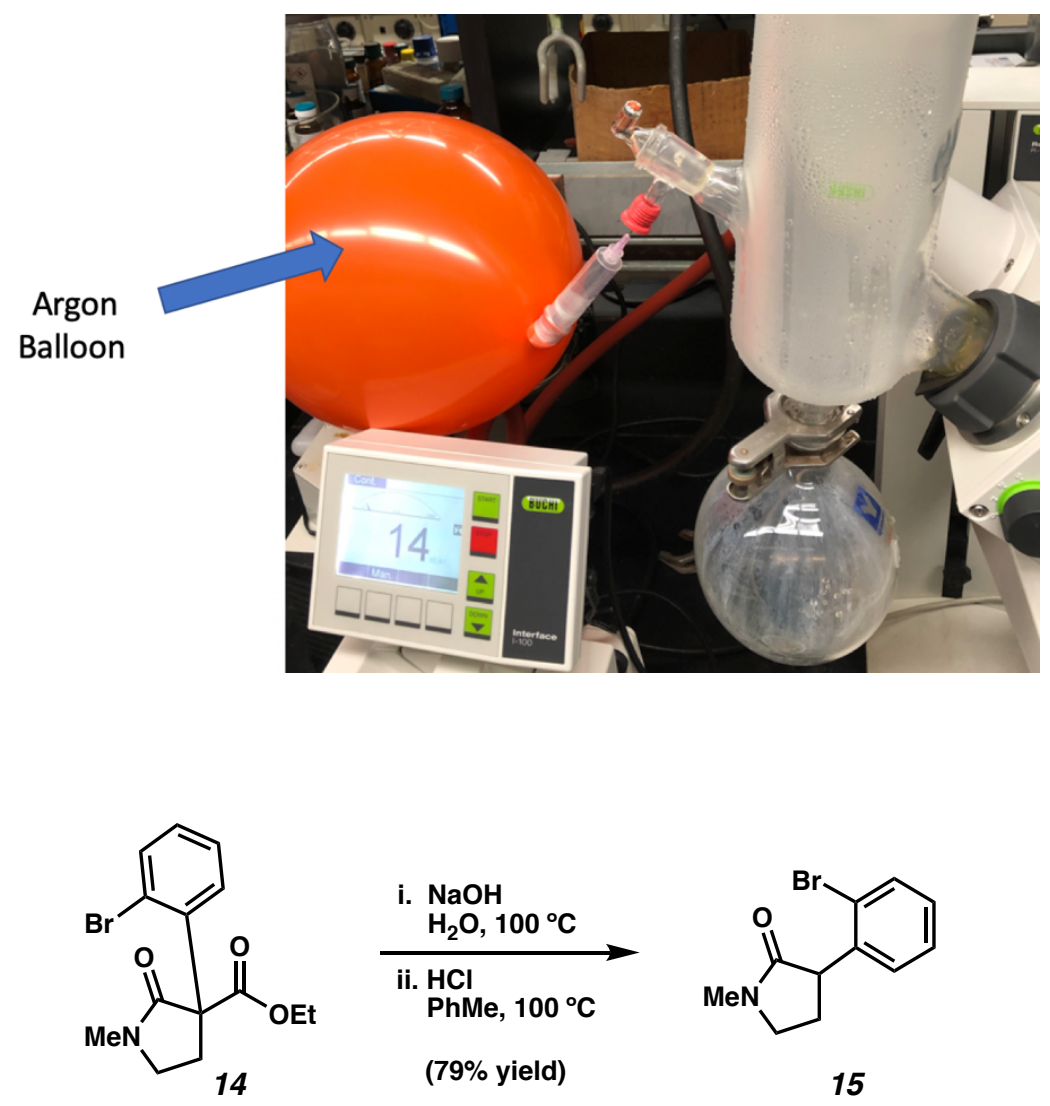

Amide 15. A suspension of pyrrolidinone 14 ( $0.550 \mathrm{~g}, 1.69 \mathrm{mmol}, 1.00$ equiv) in aq. $\mathrm{NaOH}$ (1.0 $\mathrm{M}, 30 \mathrm{~mL}$ ) was submerged in an oil bath preheated to $115^{\circ} \mathrm{C}$ and stirred for 30 minutes before being allowed to cool to $23{ }^{\circ} \mathrm{C}$. Aq. $\mathrm{HCl}(12 \mathrm{M})$ was added over 1 minute until the solution reached $\mathrm{pH}$ 1. $\mathrm{PhMe}(30 \mathrm{~mL})$ was added and the reaction was submerged in an oil bath preheated to 115 
${ }^{\circ} \mathrm{C}$ and stirred for $1 \mathrm{~h}$. The reaction was then cooled to $23{ }^{\circ} \mathrm{C}$ and poured into a biphasic mixture of $\mathrm{DI} \mathrm{H}_{2} \mathrm{O}(100 \mathrm{~mL})$ and $\mathrm{CH}_{2} \mathrm{Cl}_{2}(100 \mathrm{~mL})$. The layers were separated, and the aqueous layer was extracted with $\mathrm{CH}_{2} \mathrm{Cl}_{2}(2 \times 100 \mathrm{~mL})$. The combined organic layers were dried over $\mathrm{MgSO}_{4}$ and concentrated under reduced pressure. The crude product was purified by flash column chromatography (15 g silica gel, 1:1 Hexanes:EtOAc) to provide amide 15 ( $0.340 \mathrm{~g}, 79 \%$ yield $)$ as a white solid. Amide 15: mp: $69.4-70.0{ }^{\circ} \mathrm{C} ; \mathrm{R}_{\mathrm{f}} 0.30$ (EtOAc); ${ }^{1} \mathrm{H}$ NMR $\left(500 \mathrm{MHz}, \mathrm{CDCl}_{3}\right) \delta$ $7.56(\mathrm{dd}, J=8.0,1.2 \mathrm{~Hz}, 1 \mathrm{H}), 7.29(\mathrm{td}, J=7.5,1.2 \mathrm{~Hz}, 1 \mathrm{H}), 7.19(\mathrm{dd}, J=7.8,1.8 \mathrm{~Hz}, 1 \mathrm{H}), 7.11$ (td, $J=7.6,1.8 \mathrm{~Hz}, 1 \mathrm{H}), 4.12(\mathrm{t}, J=9.2 \mathrm{~Hz}, 1 \mathrm{H}), 3.64-3.26(\mathrm{~m}, 2 \mathrm{H}), 2.97(\mathrm{~s}, 3 \mathrm{H}), 2.73-2.56$ (m, $1 \mathrm{H}), 1.93(\mathrm{dq}, J=12.9,8.6 \mathrm{~Hz}, 1 \mathrm{H}) ;{ }^{13} \mathrm{C} \mathrm{NMR}\left(125 \mathrm{MHz}, \mathrm{CDCl}_{3}\right) \delta 174.3,139.9,133.1$, 129.4, 128.7, 128.1, 125.0, 48.4 47.6, 30.3, 27.7; HRMS (DART) calcd for $\mathrm{C}_{11} \mathrm{H}_{13} \mathrm{BrNO}[\mathrm{M}+\mathrm{H}]^{+}$, 254.0175; found 254.0169.

Note: The ester starting material is not soluble in aqueous $\mathrm{NaOH}$. The ester completely dissolves over the course of the reaction and the mixture should be homogenous at the end of heating.

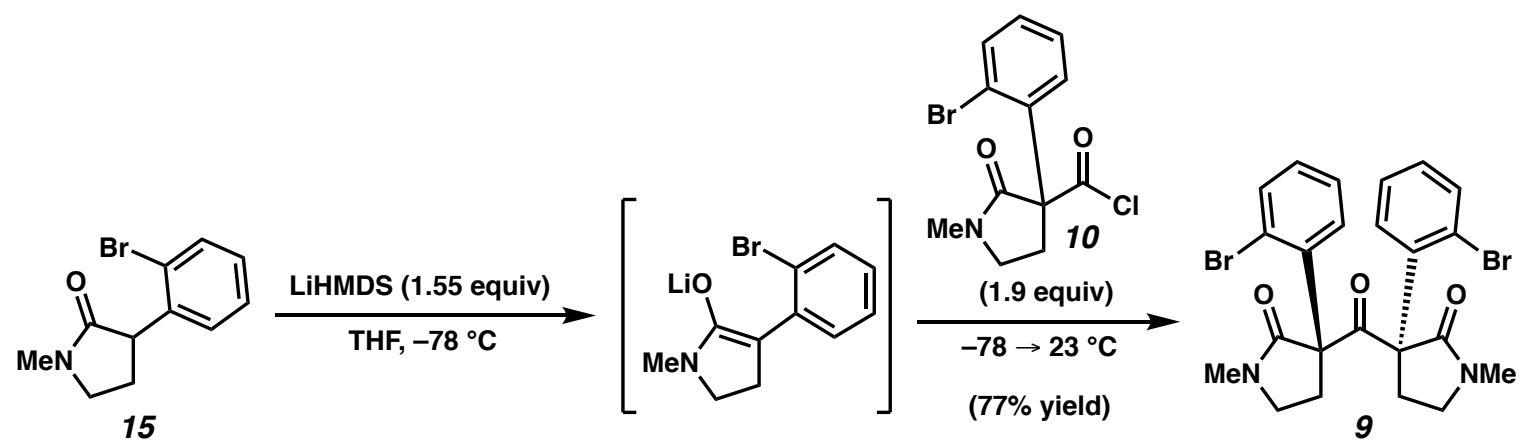

Ketone 9. To a solution of LiHMDS (1.0 M in THF, $2.0 \mathrm{~mL}, 340 \mathrm{mg}, 2.0 \mathrm{mmol}, 1.6$ equiv) was added THF $(10 \mathrm{~mL})$ and the mixture was cooled to $-78{ }^{\circ} \mathrm{C}$. A solution of amide $\mathbf{1 5}(328 \mathrm{mg}, 1.29$ mmol, 1.00 equiv) in THF $(10 \mathrm{~mL})$ was added dropwise over 15 minutes and the reaction was stirred for at $-78{ }^{\circ} \mathrm{C}$ for $1 \mathrm{~h}$. A solution of freshly prepared acid chloride 10 (420 $\mathrm{mg}, 1.6 \mathrm{mmol}$, 
1.9 equiv) in THF $(10 \mathrm{~mL})$ was added dropwise over 5 minutes. The reaction was immediately removed from the $-78^{\circ} \mathrm{C}$ bath and stirred at $23{ }^{\circ} \mathrm{C}$ for 30 minutes. The reaction was quenched by pouring it into a biphasic mixture of sat. aq. $\mathrm{NaCl}(50 \mathrm{~mL})$ and aq. $\mathrm{HCl}(1.0 \mathrm{M}, 50 \mathrm{~mL})$. The layers were separated and the aqueous layer was extracted with $\mathrm{CH}_{2} \mathrm{Cl}_{2}(3 \times 100 \mathrm{~mL})$. The combined organic layers were dried over $\mathrm{MgSO}_{4}$ and concentrated directly onto silica gel (3.5 g). The crude product was purified by flash column chromatography (15 g silica gel, 7:3 Hexanes:EtOAc $\rightarrow$ 1:1 Hexanes:EtOAc) to give ketone 9 (533 mg, 77\% yield) as a white solid. Crystals suitable for Xray diffraction studies were obtained using slow evaporation from a mixture of $\mathrm{CH}_{2} \mathrm{Cl}_{2} / \mathrm{Hexanes}$. Ketone 9: mp: $195.0-195.2{ }^{\circ} \mathrm{C} ; \mathrm{R}_{\mathrm{f}} 0.30$ (1:1 Hexanes:EtOAc); ${ }^{1} \mathrm{H}$ NMR $\left(500 \mathrm{MHz}, \mathrm{CDCl}_{3}\right) \delta 7.83$ (dd, $J=8.0,1.7 \mathrm{~Hz}, 2 \mathrm{H}), 7.62(\mathrm{dd}, J=7.9,1.4 \mathrm{~Hz}, 2 \mathrm{H}), 7.29-7.23(\mathrm{~m}, 2 \mathrm{H}), 7.13(\mathrm{td}, J=7.6,1.7$ $\mathrm{Hz}, 2 \mathrm{H}), 3.62$ (ddd, $J=13.1,8.3,4.7 \mathrm{~Hz}, 2 \mathrm{H}), 3.37$ (ddd, $J=9.6,8.3,5.6 \mathrm{~Hz}, 2 \mathrm{H}), 3.13$ (ddd, $J=$ 9.5, 8.1, $4.8 \mathrm{~Hz}, 2 \mathrm{H}), 2.88$ (s, 6H), 2.42 (ddd, $J=13.4,8.1,5.6 \mathrm{~Hz}, 2 \mathrm{H}) ;{ }^{13} \mathrm{C}$ NMR $(125 \mathrm{MHz}$, $\left.\mathrm{CDCl}_{3}\right) \delta 197.4,171.1,138.6,135.7,131.2,129.2,127.2,123.9,70.3,46.8,31.1,30.9$; HRMSAPCI (m/z) $[\mathrm{M}+\mathrm{H}]^{+}$calcd for $\mathrm{C}_{23} \mathrm{H}_{23} \mathrm{~N}_{2} \mathrm{O}_{3} \mathrm{Br}_{2}^{+}, 535.0050$; found 535.0039.
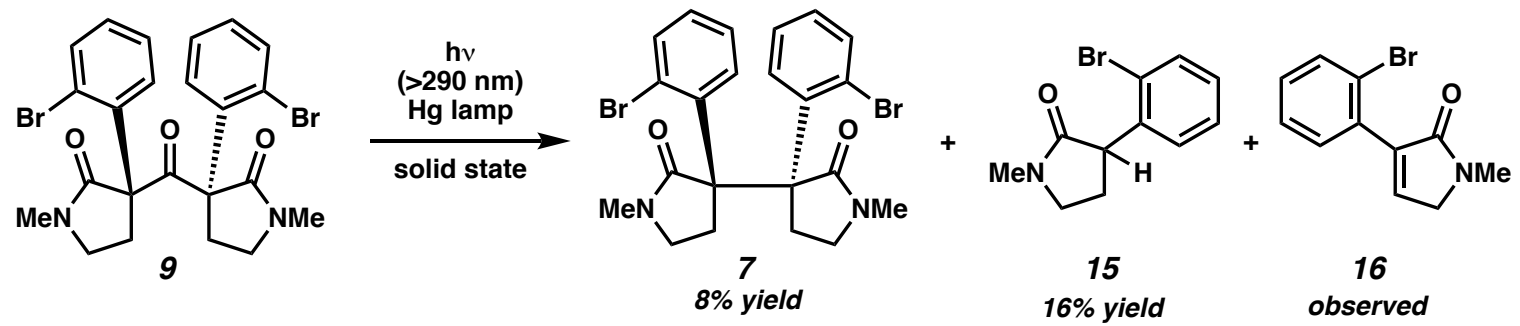

$N$-Me Bis(arylbromide) 7. Ketone $9(30-50 \mathrm{mg})$ was dissolved in $\mathrm{CH}_{2} \mathrm{Cl}_{2}(\sim 5 \mathrm{~mL})$ and Hexanes $(\sim 3 \mathrm{~mL})$ were added until the mixture became cloudy. This was allowed to evaporate over $\sim 16 \mathrm{~h}$. Once crystals had formed, the residual solvent was removed using a glass Pasteur pipette. The resultant crystalline solid was put under high vacuum $(<1 \mathrm{mbar})$ for $1 \mathrm{~h}$. A small sample of 
crystalline 9 ( $4.50 \mathrm{mg}, 8.42 \mu \mathrm{mol})$ was placed between two glass microscope slides. The two slides were rubbed together for 10 seconds to crush 9 into a thin layer of crystalline powder (Note 1). The two glass slides were then clamped together using two binder clips. The solid sample was irradiated with a $450 \mathrm{~W}$ medium pressure Hg Hanovia UV lamp placed inside a water-cooled immersion-well Pyrex filter (Ace Glass, model 7857-05, $\lambda \geq 290 \mathrm{~nm} ; 53 \mathrm{~mm}$ external diameter, $220 \mathrm{~mm}$ full length, $150 \mathrm{~mm}$ depth) for $7 \mathrm{~h}$ (see Note 3 for reaction monitoring). At this time, the sample was flipped over (to expose the other side of the solid to light) and then irradiated for another $18 \mathrm{~h}$. The binder clips were then removed and a metal spatula was used to scrape the solid off of the glass slides into a vial. The slides and spatula were then rinsed with $\mathrm{CDCl}_{3}(\sim 5 \mathrm{~mL})$ to give a mixture of $N$-Me bis(arylbromide) $7(0.32 \mathrm{mg}, 8 \%$ yield $)$ and disproportionation product 15 (0.33 mg, 16\% yield). (Yield determined by ${ }^{1} \mathrm{H}$ QNMR with 1,4-dinitrobenzene as the external standard). Characterization data for $\mathbf{7}$ is reported later in this document (S20-S21).

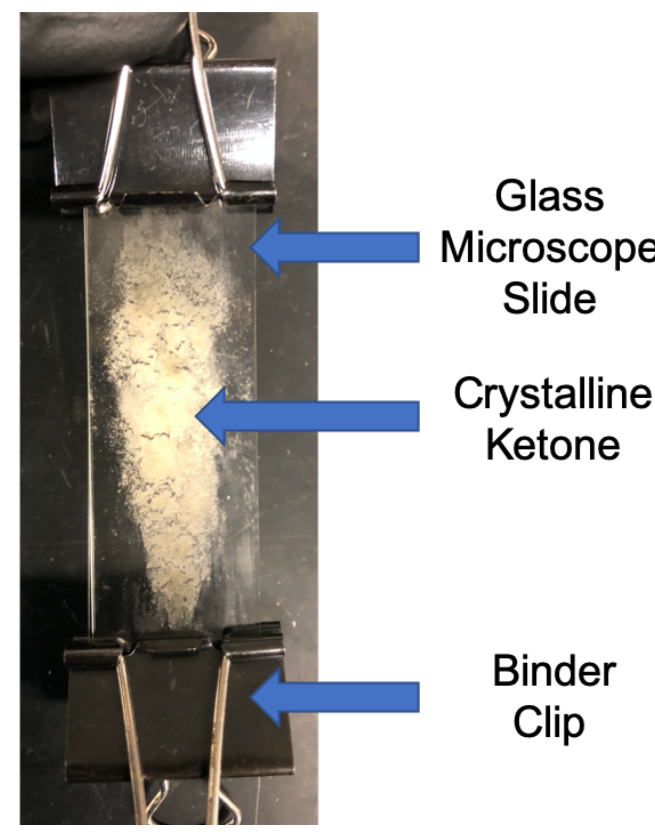

Note 1: It is critical that the solid is crushed into a very thin layer to ensure adequate light penetration. 
Note 2: The 450W Hg lamp produces significant heat. This is mitigated by the jacket of cooling water and fans to circulate warm air out of the box containing the irradiation setup.

Note 3: This particular reaction was not monitored by TLC in order to ensure accurate yield determination. In general, to monitor the reaction by $T L C$, a very small aliquot $(<0.1 \mathrm{mg})$ of solid is removed with the tip of a glass Pasteur pipette. This solid is then dissolved in $\sim 1$ drop of $\mathrm{CH}_{2} \mathrm{Cl}_{2}$ and analyzed by TLC. Since the product 7 is difficult to visualize, conversion is determined by loss of the spot corresponding to ketone 9.

Note 4: While some of the mass balance is attributed to disproportionation and unidentified decomposition products, a substantial amount of insoluble yellow solid is produced. The identity of this material is unknown.

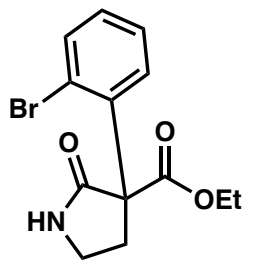

13

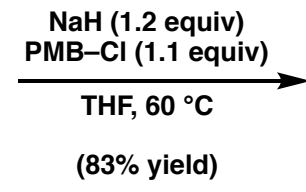

$(83 \%$ yield $)$

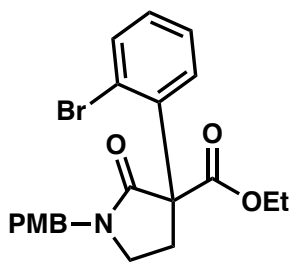

30

PMB Pyrrolidinone 30. To a solution of pyrrolidinone 13 (6.70 g, $25.0 \mathrm{mmol}, 1.00$ equiv) in THF $(250 \mathrm{~mL})$ was added $\mathrm{NaH}(1.21 \mathrm{~g}, 60 \%$ dispersion in mineral oil, $30.3 \mathrm{mmol}, 1.21$ equiv, 60\%) in one portion and the reaction was stirred for 5 minutes. 4-Methoxybenzyl chloride $(3.75 \mathrm{~mL}, 4.35$ $\mathrm{g}, 27.8 \mathrm{mmol}, 1.11$ equiv) was added dropwise over 1 minute and the reaction was submerged in an oil bath preheated to $60{ }^{\circ} \mathrm{C}$. The reaction was stirred for $5 \mathrm{~h}$ and then allowed to cool to $23^{\circ} \mathrm{C}$. The reaction was poured into a biphasic mixture of sat. aq. $\mathrm{NH}_{4} \mathrm{Cl}(300 \mathrm{~mL})$ and EtOAc $(200 \mathrm{~mL})$. The layers were separated, and the aqueous layer was extracted with EtOAc $(2 \times 100 \mathrm{~mL}) \cdot \mathrm{CH}_{2} \mathrm{Cl}_{2}$ $(250 \mathrm{~mL})$ was added to the combined organic layers and the solution was dried over $\mathrm{Na}_{2} \mathrm{SO}_{4}$ and 
concentrated under reduced pressure directly onto silica gel (20 g). The crude product was purified by flash column chromatography ( $80 \mathrm{~g}$ silica gel, 9:1 Hexanes:EtOAc $\rightarrow$ 7:3 Hexanes:EtOAc) to give pyrrolidinone $\mathbf{3 0}$ as a glassy solid (7.91 g, 83\% yield). Pyrrolidinone 30: $\mathrm{R}_{\mathrm{f}} 0.69$ (2:3 Hexanes:EtOAc); ${ }^{1} \mathrm{H}$ NMR $\left(500 \mathrm{MHz}, \mathrm{CDCl}_{3}\right) \delta 7.58(\mathrm{~d}, J=7.9 \mathrm{~Hz}, 1 \mathrm{H}), 7.33(\mathrm{~d}, J=8.0 \mathrm{~Hz}, 1 \mathrm{H})$, $7.28-7.25(\mathrm{~m}, 1 \mathrm{H}), 7.24-7.20(\mathrm{~m}, 2 \mathrm{H}), 7.14(\mathrm{t}, J=7.6 \mathrm{~Hz}, 1 \mathrm{H}), 6.92-6.73(\mathrm{~m}, 2 \mathrm{H}), 4.59(\mathrm{~d}, J$ $=14.5 \mathrm{~Hz}, 1 \mathrm{H}), 4.47(\mathrm{~d}, J=14.4 \mathrm{~Hz}, 1 \mathrm{H}), 4.35-4.15(\mathrm{~m}, 2 \mathrm{H}), 3.80(\mathrm{~s}, 3 \mathrm{H}), 3.44-3.25(\mathrm{~m}, 2 \mathrm{H})$, $3.17-2.96(\mathrm{~m}, 1 \mathrm{H}), 2.33-2.03(\mathrm{~m}, 1 \mathrm{H}), 1.25(\mathrm{t}, J=7.1 \mathrm{~Hz}, 3 \mathrm{H}) ;{ }^{13} \mathrm{C} \mathrm{NMR}\left(125 \mathrm{MHz}, \mathrm{CDCl}_{3}\right) \delta$ $170.5,170.2,159.4,139.1,134.2,129.8,129.3,129.0,128.0,127.7,124.1,114.3,63.7,62.6,55.4$, 47.1, 43.8, 31.3, 14.1; HRMS-APCI (m/z) $[\mathrm{M}+\mathrm{H}]^{+}$calcd for $\mathrm{C}_{21} \mathrm{H}_{23} \mathrm{BrNO}_{4}{ }^{+}, 432.0805$; found, 432.0805 .
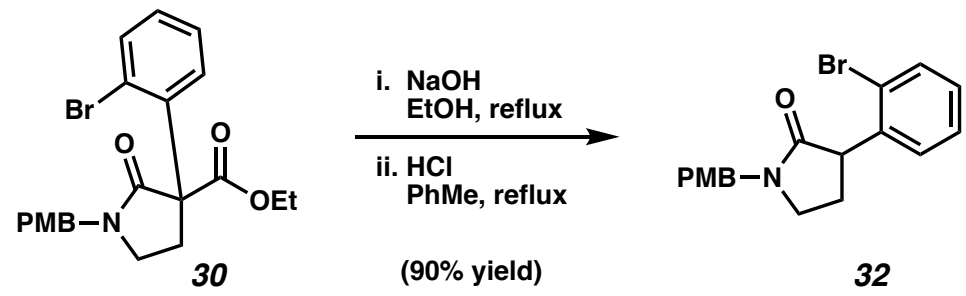

PMB Amide 32. A solution of pyrrolidinone 30 (3.16 g, $7.82 \mathrm{mmol}, 1.00$ equiv) in EtOH (140 $\mathrm{mL}$ ) was submerged in an oil bath preheated to $100{ }^{\circ} \mathrm{C}$ and stirred until all the solids had dissolved ( 10 minutes). Aq. $\mathrm{NaOH}(1.0 \mathrm{M}, 70 \mathrm{~mL})$ was added and the refluxing solution was stirred for 30 minutes and then allowed to cool to $23{ }^{\circ} \mathrm{C}$. Aq. $\mathrm{HCl}(12 \mathrm{M}, 16 \mathrm{~mL})$ and $\mathrm{PhMe}(80 \mathrm{~mL})$ were added sequentially. The reaction was then submerged in an oil bath preheated to $100^{\circ} \mathrm{C}$, stirred for $6 \mathrm{~h}$, and then allowed to cool to $23^{\circ} \mathrm{C}$. The reaction mixture was poured into $\mathrm{DI} \mathrm{H}_{2} \mathrm{O}(200 \mathrm{~mL})$ and the layers were separated. The aqueous layer was extracted with $\mathrm{CH}_{2} \mathrm{Cl}_{2}(2 \times 60 \mathrm{~mL})$. The combined organic layers were dried over $\mathrm{Na}_{2} \mathrm{SO}_{4}$ and then concentrated under reduced pressure to give PMB amide 32 (2.54 g, 90\% yield) as a glassy solid. This was used without further purification. Amide 
32: $\mathrm{R}_{\mathrm{f}} 0.41\left(1: 1\right.$ Hexanes:EtOAc); ${ }^{1} \mathrm{H} \mathrm{NMR}\left(500 \mathrm{MHz}, \mathrm{CDCl}_{3}\right) \delta 7.56(\mathrm{~d}, J=8.0 \mathrm{~Hz}, 1 \mathrm{H}), 7.29(\mathrm{t}$, $J=7.5 \mathrm{~Hz}, 1 \mathrm{H}), 7.26-7.23(\mathrm{~m}, 2 \mathrm{H}), 7.20(\mathrm{~d}, J=7.6 \mathrm{~Hz}, 1 \mathrm{H}), 7.11(\mathrm{t}, J=7.7 \mathrm{~Hz}, 1 \mathrm{H}), 6.92-6.85$ $(\mathrm{m}, 2 \mathrm{H}), 4.57(\mathrm{~d}, J=14.4 \mathrm{~Hz}, 1 \mathrm{H}), 4.44(\mathrm{~d}, J=14.4 \mathrm{~Hz}, 1 \mathrm{H}), 4.16(\mathrm{t}, J=9.2 \mathrm{~Hz}, 1 \mathrm{H}), 3.82(\mathrm{~s}, 3 \mathrm{H})$, $3.35-3.18(\mathrm{~m}, 2 \mathrm{H}), 2.58(\mathrm{dddd}, J=10.9,9.5,5.6,3.4 \mathrm{~Hz}, 1 \mathrm{H}), 1.88(\mathrm{dq}, J=12.9,8.6 \mathrm{~Hz}, 1 \mathrm{H})$; ${ }^{13} \mathrm{C}$ NMR $\left(125 \mathrm{MHz}, \mathrm{CDCl}_{3}\right) \delta 173.9,159.2,139.7,133.0,129.7,129.3,128.6,128.5,128.0$, 124.9, 114.1, 55.3, 48.7, 46.6, 44.6, 27.5; HRMS-APCI (m/z) $[\mathrm{M}+\mathrm{H}]^{+}$calcd for $\mathrm{C}_{18} \mathrm{H}_{19} \mathrm{BrNO}_{2}{ }^{+}$, 360.0594; found, 360.0593 .
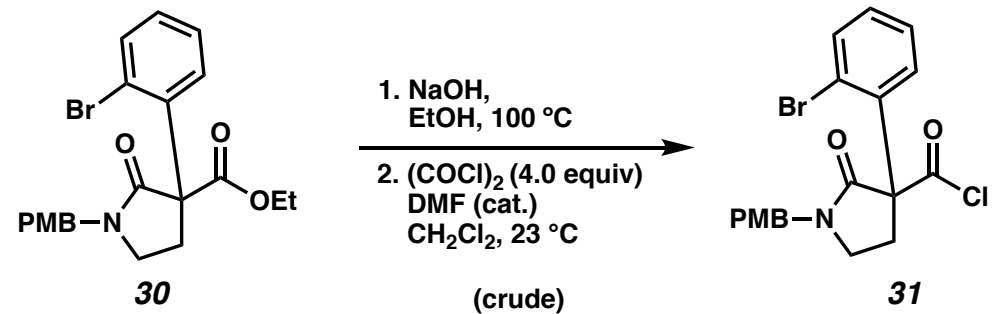

PMB Acid Chloride 31. A solution of pyrrolidinone 30 (4.74 g, $11.0 \mathrm{mmol}, 1.00$ equiv) in EtOH $(60 \mathrm{~mL})$ was submerged in an oil bath preheated to $100{ }^{\circ} \mathrm{C}$ and stirred until all the solids had dissolved ( $\sim 10 \mathrm{~min})$. Aq. $\mathrm{NaOH}(1.0 \mathrm{M}, 60 \mathrm{~mL})$ was added to the refluxing solution and the mixture was stirred for 15 minutes before the mixture was allowed to cool to $23{ }^{\circ} \mathrm{C}$. The reaction mixture was poured into a biphasic mixture of aq. $\mathrm{HCl}(200 \mathrm{~mL}, 1.0 \mathrm{M})$ and $\mathrm{CH}_{2} \mathrm{Cl}_{2}(150 \mathrm{~mL})$ and the layers were separated. The aqueous layer was extracted with $\mathrm{CH}_{2} \mathrm{Cl}_{2}(100 \mathrm{~mL})$. The combined organic layers were dried over $\mathrm{MgSO}_{4}$ and then concentrated under reduced pressure directly onto silica gel (12 g). The crude product was purified using a (12 g RediSep Gold, 1:1 Hexanes:EtOAc $\rightarrow 100 \%$ EtOAc) to provide the corresponding carboxylic acid (3.95 g, 89\% yield) as a white solid.

To the solid carboxylic acid (3.95 g, $9.77 \mathrm{mmol}, 1.00$ equiv) was added two drops of DMF (using a glass Pasteur pipette) and $\mathrm{CH}_{2} \mathrm{Cl}_{2}(100 \mathrm{~mL})$. Oxalyl chloride (2.25 mL, $4.96 \mathrm{~g}, 39.0 \mathrm{mmol}$, 
3.99 equiv) was added to the mixture dropwise over 5 minutes. The reaction was stirred at $23{ }^{\circ} \mathrm{C}$ for $16 \mathrm{~h}$ and then concentrated under reduced pressure. The oil was dissolved in PhMe (30 mL) and concentrated under reduced pressure (x2). The crude oil was then put under high vacuum $(<1$ mbar) for $1 \mathrm{~h}$. Crude acid chloride 31 was used directly in the next step without further purification. Note 1: It is critical that this set up is kept anhydrous and that the excess oxalyl chloride is fully removed at the end of the reaction. Each time the acid chloride was concentrated under rotary evaporation (both from $\mathrm{CH}_{2} \mathrm{Cl}_{2}$ and then from $\mathrm{PhMe}$ ) the water bath was maintained at $50{ }^{\circ} \mathrm{C}$ and the vacuum was maintained at the highest setting ( 15 mbar) for 15 minutes. After this, it is recommended that the oil be put under high vacuum (<1 mbar) for $1 \mathrm{~h}$.

Note 2: In order to ensure that undue water is not introduced between rotary evaporations, the rotary evaporator is backfilled with a balloon of dry Ar (see image below).
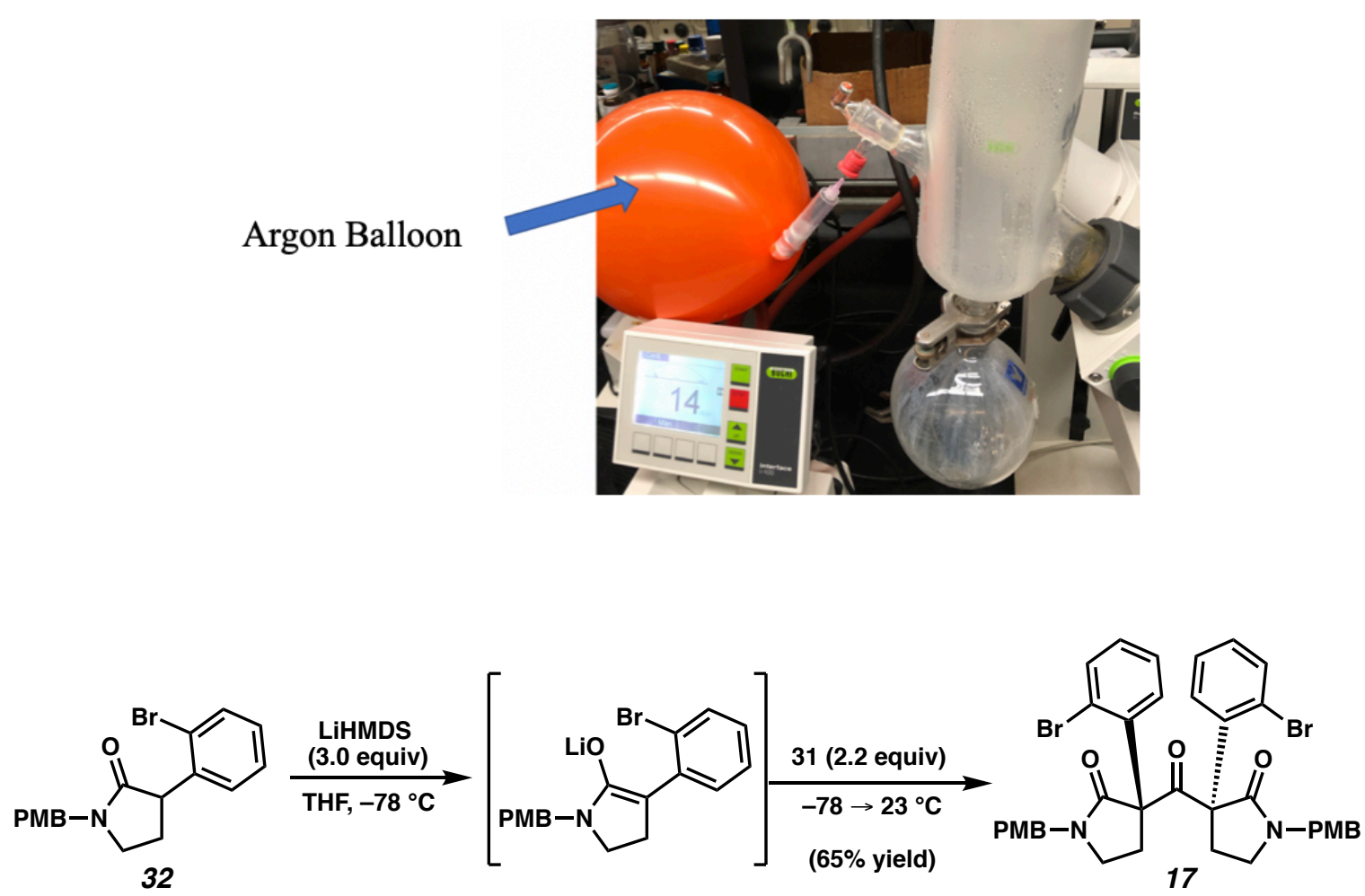
Ketone 17. To a solution of amide $32\left(0.710 \mathrm{~g}, 2.00 \mathrm{mmol}, 1.00\right.$ equiv) in THF $(30 \mathrm{~mL})$ at $-78^{\circ} \mathrm{C}$ was added a solution of LiHMDS (1.0 M in THF, $5.9 \mathrm{~mL}, 990 \mathrm{mg}, 5.9 \mathrm{mmol}, 3.0$ equiv) dropwise over 1 minute. The reaction was stirred for $1 \mathrm{~h}$ and then a solution of acid chloride $\mathbf{3 1}$ (2.0 g, 2.4 mmol, 2.2 equiv) in THF (16 mL) was added dropwise over 1 minute and the reaction was immediately removed from the $-78^{\circ} \mathrm{C}$ bath, placed in a $0{ }^{\circ} \mathrm{C}$ bath, and the reaction was stirred for 35 minutes. The reaction was quenched at $0{ }^{\circ} \mathrm{C}$ by the addition of aq. $\mathrm{HCl}(0.5 \mathrm{M}, 6 \mathrm{~mL})$ and poured into a biphasic mixture of $\mathrm{DI} \mathrm{H}_{2} \mathrm{O}(100 \mathrm{~mL})$, sat. aq. $\mathrm{NaCl}(100 \mathrm{~mL})$, and $\mathrm{CH}_{2} \mathrm{Cl}_{2}(100$ $\mathrm{mL})$. The layers were separated, and the aqueous layer was extracted with $\mathrm{CH}_{2} \mathrm{Cl}_{2}(2 \times 100 \mathrm{~mL})$. The combined organic layers were dried over $\mathrm{Na}_{2} \mathrm{SO}_{4}$ and concentrated under reduced pressure directly onto silica gel ( $2 \mathrm{~g})$. The crude product was purified by flash column chromatography (20 g silica gel, 4:1 Hexanes:EtOAc) to give ketone 17 (963 mg, 65\% yield) as a white foam. Ketone 17: $\mathrm{R}_{\mathrm{f}} 0.44$ (3:2 Hexanes:EtOAc); ${ }^{1} \mathrm{H}$ NMR (500 MHz, $\left.\mathrm{CDCl}_{3}\right) \delta 7.89(\mathrm{~d}, J=8.0 \mathrm{~Hz}, 2 \mathrm{H}), 7.64$ $(\mathrm{d}, J=7.9 \mathrm{~Hz}, 2 \mathrm{H}), 7.36-7.23(\mathrm{~m}, 6 \mathrm{H}), 7.15(\mathrm{td}, J=7.7,1.5 \mathrm{~Hz}, 2 \mathrm{H}), 6.93-6.73(\mathrm{~m}, 4 \mathrm{H}), 4.99$ $(\mathrm{d}, J=14.6 \mathrm{~Hz}, 2 \mathrm{H}), 4.00(\mathrm{~d}, J=14.6 \mathrm{~Hz}, 2 \mathrm{H}), 3.79(\mathrm{~s}, 6 \mathrm{H}), 3.62(\mathrm{ddd}, J=13.2,8.1,5.0 \mathrm{~Hz}, 2 \mathrm{H})$, $3.27(\mathrm{td}, J=8.7,5.3 \mathrm{~Hz}, 2 \mathrm{H}), 3.00(\mathrm{td}, J=8.5,5.0 \mathrm{~Hz}, 2 \mathrm{H}), 2.43(\mathrm{ddd}, J=13.2,7.9,5.3 \mathrm{~Hz}, 2 \mathrm{H})$; ${ }^{13} \mathrm{C}$ NMR $\left(125 \mathrm{MHz}, \mathrm{CDCl}_{3}\right) \delta 197.0,171.0,159.1,138.1,135.6,131.2,130.0,129.1,128.0$, 127.1, 123.7, 114.0, 70.7, 55.3, 47.6, 44.2, 30.8; HRMS-APCI $(\mathrm{m} / \mathrm{z})[\mathrm{M}+\mathrm{H}]^{+}$calcd for $\mathrm{C}_{37} \mathrm{H}_{35} \mathrm{Br}_{2} \mathrm{~N}_{2} \mathrm{O}_{5}^{+}$, 747.0887; found, 747.0892.

Note 1: It is critical that amide 32 is completely dry. To ensure this, 32 was concentrated from anhydrous benzene before the reaction was set up to remove residual water.

Note 2: In the event that residual enolate precursor 32 remains after the reaction, separation of ketone 17 and pyrrolidinone 32 is tedious. To circumvent this, 32 can be decomposed by treating the mixture of 32 and 17 with LiHMDS in THF at $-78^{\circ} \mathrm{C}$ (see conditions to form ketone above) 
and then quenching the resultant enolate with $\left(\mathrm{CH}_{2} \mathrm{O}\right)_{n}$ (5 equiv). This cleanly hydroxymethylated any residual 32. The resultant impurity that now bears a hydroxymethyl group is sufficiently polar that it can be easily removed from ketone 17 via column chromatography.
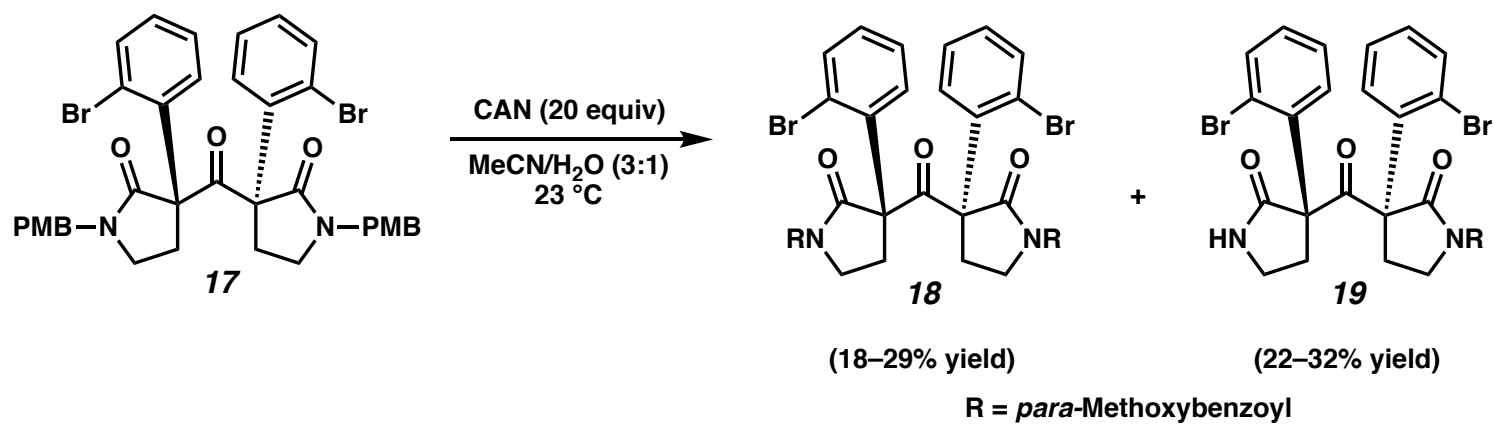

Ketones 18 \& 19. To a solution of ketone 17 ( $2.01 \mathrm{~g}, 2.69 \mathrm{mmol}, 1.00$ equiv) in $\mathrm{MeCN}$ ( $285 \mathrm{~mL})$ were added $\mathrm{DI} \mathrm{H}_{2} \mathrm{O}(95 \mathrm{~mL})$ followed by ceric ammonium nitrate (CAN) (29.4 g, $53.9 \mathrm{mmol}, 20.0$ equiv) in one portion. The reaction mixture was stirred at $23{ }^{\circ} \mathrm{C}$ for 90 minutes. The resultant solution was poured into a biphasic mixture of $\mathrm{DI} \mathrm{H}_{2} \mathrm{O}(800 \mathrm{~mL})$ and $\mathrm{CH}_{2} \mathrm{Cl}_{2}(400 \mathrm{~mL})$. The layers were separated, and the aqueous layer was extracted with $\mathrm{CH}_{2} \mathrm{Cl}_{2}(2 \times 300 \mathrm{~mL})$. The combined organic layers were dried over $\mathrm{MgSO}_{4}$ and concentrated directly onto silica gel (4 g). The crude product was purified by flash column chromatography (24 g RediSep Gold, 7:3 Hexanes:EtOAc $\rightarrow 100 \%$ EtOAc) to give a ketone 18 (375 mg, 18\% yield) and ketone 19 (550 mg, 32\% yield). Note that these the yield of $\mathbf{1 8}$ ranges from $18-29 \%$ and the yield of 19 ranges from $22-32 \%$. Crystals of both 18 and 19 suitable for X-ray diffraction studies (18, CCDC 1999793; 19, CCDC 1999794) were obtained as follows: pure ketone $(15 \mathrm{mg})$ was dissolved in minimal $\mathrm{CHCl}_{3}(\sim 2$ $\mathrm{mL})$. $n$ Hexane $(\sim 6 \mathrm{~mL})$ was layered on top of $\mathrm{CHCl}_{3}$ solution and the layers were allowed to slowly diffuse together over 3 days. This furnished high quality single crystals that were amenable to Xray diffraction. Ketone 18: $\mathrm{R}_{\mathrm{f}} 0.48\left(1: 1 \mathrm{Hexanes:EtOAc);}{ }^{1} \mathrm{H}\right.$ NMR $\left(500 \mathrm{MHz}, \mathrm{CDCl}_{3}\right) \delta 7.76-$ 
$7.68(\mathrm{~m}, 4 \mathrm{H}), 7.66-7.61(\mathrm{~m}, 4 \mathrm{H}), 7.33(\mathrm{td}, J=7.7,1.4 \mathrm{~Hz}, 2 \mathrm{H}), 7.22(\mathrm{td}, J=7.6,1.6 \mathrm{~Hz}, 2 \mathrm{H})$, $6.82-6.75(\mathrm{~m}, 4 \mathrm{H}), 3.89(\mathrm{ddd}, J=10.2,7.3,5.2 \mathrm{~Hz}, 2 \mathrm{H}), 3.75(\mathrm{~s}, 6 \mathrm{H}), 3.59(\mathrm{dt}, J=13.5,7.0 \mathrm{~Hz}$, 2H), $3.45(\mathrm{dt}, J=10.8,6.8 \mathrm{~Hz}, 2 \mathrm{H}), 2.70(\mathrm{ddd}, J=12.9,7.1,5.5 \mathrm{~Hz}, 2 \mathrm{H}) ;{ }^{13} \mathrm{C} \mathrm{NMR}(125 \mathrm{MHz}$, $\left.\mathrm{CDCl}_{3}\right) \delta 194.5,172.5,169.3,162.8,136.1,135.7,131.8,131.0,129.9,127.5,125.9,123.3,113.2$, 72.1, 55.3, 45.1, 30.0; HRMS-APCI (m/z) $[\mathrm{M}+\mathrm{H}]^{+}$calcd for $\mathrm{C}_{37} \mathrm{H}_{31} \mathrm{Br}_{2} \mathrm{~N}_{2} \mathrm{O}_{7}{ }^{+}$, 775.0472; found, 775.0476. Ketone 19: $\mathrm{R}_{\mathrm{f}} 0.30$ (3:2 Hexanes:EtOAc); ${ }^{1} \mathrm{H}$ NMR $\left(500 \mathrm{MHz}, \mathrm{CDCl}_{3}\right) \delta 7.91(\mathrm{~d}, J=$ $8.0 \mathrm{~Hz}, 1 \mathrm{H}), 7.88-7.82(\mathrm{~m}, 2 \mathrm{H}), 7.72-7.62(\mathrm{~m}, 2 \mathrm{H}), 7.59(\mathrm{dd}, J=8.0,1.7 \mathrm{~Hz}, 1 \mathrm{H}), 7.32(\mathrm{td}, J=$ 7.7, $1.5 \mathrm{~Hz}, 1 \mathrm{H}), 7.29-7.26(\mathrm{~m}, 1 \mathrm{H}), 7.23-7.14(\mathrm{~m}, 2 \mathrm{H}), 6.99-6.88(\mathrm{~m}, 2 \mathrm{H}), 5.46(\mathrm{~s}, 1 \mathrm{H}), 3.97$ $-3.83(\mathrm{~m}, 4 \mathrm{H}), 3.63-3.44(\mathrm{~m}, 3 \mathrm{H}), 3.29-3.21(\mathrm{~m}, 1 \mathrm{H}), 3.04(\mathrm{dt}, J=9.4,6.8 \mathrm{~Hz}, 1 \mathrm{H}), 2.79-$ $2.61(\mathrm{~m}, 2 \mathrm{H}) ;{ }^{13} \mathrm{C} \mathrm{NMR}\left(125 \mathrm{MHz}, \mathrm{CDCl}_{3}\right) \delta 195.8,174.7,172.2,169.9,162.8,136.5,136.4$, $136.1,135.9,131.9,131.5,131.4,129.72,129.70,127.6,127.4,126.9,124.0,123.3,113.1,72.8$, 69.0, 55.5, 44.6, 39.6, 33.4, 29.8; HRMS-APCI $(\mathrm{m} / \mathrm{z})[\mathrm{M}+\mathrm{H}]^{+}$calcd for $\mathrm{C}_{29} \mathrm{H}_{25} \mathrm{Br}_{2} \mathrm{~N}_{2} \mathrm{O}_{5}{ }^{+}$, 641.0104; found, 641.0104.

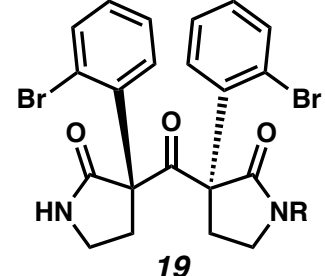

19

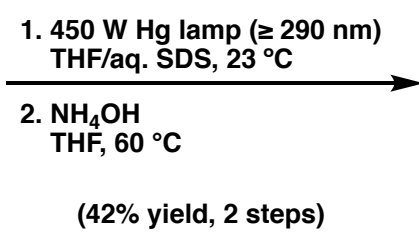

(42\% yield, 2 steps)

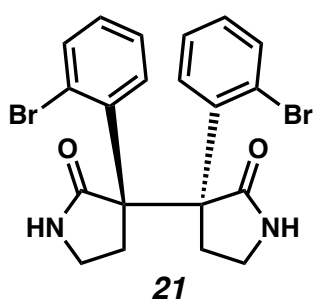

21

$\mathbf{R}=$ para-Methoxybenzoyl

Bis(arylbromide) 21. Ketone 19 (235 mg, $0.367 \mathrm{mmol}, 1.00$ equiv) was dissolved in THF (18 $\mathrm{mL})$. An aliquot $(3 \mathrm{~mL})$ was added dropwise into a vortexing aqueous solution of sodium dodecyl sulfate $(0.7 \mathrm{mg} / \mathrm{mL}, 30 \mathrm{~mL})$ (see Note 1 for vortexing procedure). This was repeated a total of six times and the resultant suspensions were combined in a $300 \mathrm{~mL}$ Pyrex tube $(5 \mathrm{~cm}$ diameter) with 
rapid stirring, giving a suspension of ketone 19 (total volume of aq. SDS $=180 \mathrm{~mL}$ ). This suspension was irradiated with a $450 \mathrm{~W}$ medium pressure Hg Hanovia UV lamp placed inside a water-cooled immersion-well Pyrex filter (Ace Glass, model 7857-05, $\lambda \geq 290 \mathrm{~nm} ; 53 \mathrm{~mm}$ external diameter, $220 \mathrm{~mm}$ full length, $150 \mathrm{~mm}$ depth) for $49 \mathrm{~h}$ (see Note 3 for reaction monitoring). The reaction was poured into a biphasic mixture of sat. aq. $\mathrm{NaCl}(150 \mathrm{~mL})$ and EtOAc $(100 \mathrm{~mL})$. The layers were separated, and the aqueous layer was extracted with EtOAc $(3 \times 75 \mathrm{~mL})$. The combined organic layers were diluted with $\mathrm{CH}_{2} \mathrm{Cl}_{2}(100 \mathrm{~mL})$ and dried over $\mathrm{Na}_{2} \mathrm{SO}_{4}$ before being concentrated under reduced pressure. Residual SDS was removed by flushing the crude oil over a short silica plug $(5 \mathrm{~cm})$ with EtOAc $(100 \mathrm{~mL})$ and the resultant solution was concentrated under reduced pressure and used without further purification.

To a solution of the crude photoproduct in THF $(30 \mathrm{~mL})$ in a heavy-walled tube, $\mathrm{NH}_{4} \mathrm{OH}$ $(30-32 \% \mathrm{w} / \mathrm{v}, 2.9 \mathrm{~mL})$ was added. The vessel was sealed with a Teflon screwcap, submerged in an oil bath preheated to $65{ }^{\circ} \mathrm{C}$ and stirred for 90 minutes. The reaction was allowed to cool to 23 ${ }^{\circ} \mathrm{C}$ and was diluted with $\mathrm{CH}_{2} \mathrm{Cl}_{2}(75 \mathrm{~mL})$. Sat. aq. $\mathrm{NaCl}(100 \mathrm{~mL})$ was added and the layers were separated. The aqueous layer was extracted with $\mathrm{CH}_{2} \mathrm{Cl}_{2}(2 \times 75 \mathrm{~mL})$ and the combined organic layers were dried over $\mathrm{Na}_{2} \mathrm{SO}_{4}$ and then concentrated under reduced pressure directly onto silica gel (0.5 g). The crude product was purified by flash column chromatography (4 g silica gel, 1:1 Hexanes:EtOAc $\rightarrow 100 \%$ EtOAc) to give the bis(arylbromide) 21 as a glassy solid (105 mg, 47\% yield). Average yield over 2 runs (43\% yield). Bis(arylbromide) 21: $\mathrm{R}_{\mathrm{f}} 0.35$ (EtOAc); ${ }^{1} \mathrm{H}$ NMR $\left(600 \mathrm{MHz}, \mathrm{CDCl}_{3}\right) \delta 8.06(\mathrm{~s}, 2 \mathrm{H}), 7.71(\mathrm{~d}, J=7.6 \mathrm{~Hz}, 2 \mathrm{H}), 7.30-7.27(\mathrm{~m}, 2 \mathrm{H}), 7.14-7.00(\mathrm{~m}$, 4H), $3.61(\mathrm{t}, J=9.6 \mathrm{~Hz}, 2 \mathrm{H}), 3.51-3.33(\mathrm{~m}, 4 \mathrm{H}), 2.81(\mathrm{td}, J=11.7,9.5,3.9 \mathrm{~Hz}, 2 \mathrm{H}) ;{ }^{13} \mathrm{C} \mathrm{NMR}$ $\left(125 \mathrm{MHz}, \mathrm{CDCl}_{3}\right) \delta 178.2,140.5,136.3,135.7,128.6,125.4,124.2,61.1,41.4,33.6$; HRMSAPCI (m/z) $[\mathrm{M}+\mathrm{H}]^{+}$calcd for $\mathrm{C}_{20} \mathrm{H}_{19} \mathrm{Br}_{2} \mathrm{~N}_{2} \mathrm{O}_{2}{ }^{+}$, 478.9787; found, 478.9775. 
Note 1: Vortexing SDS solution: A 50 mL graduated cylinder containing 30 mL SDS solution (0.7 $m g / m L$ in $\mathrm{DI} \mathrm{H} \mathrm{H}_{2} \mathrm{O}$ ) was placed on a Thermo-Fischer Maxi-Mix ${ }^{\circledR} 0.5 \mathrm{~W}, 60 \mathrm{~Hz}$ vortex mixer. Once the aq. solution was rapidly vortexing, the solution of ketone in SDS was added dropwise from a syringe (see image below).

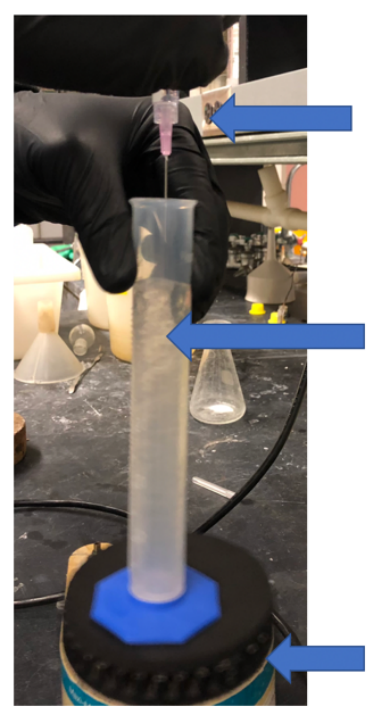

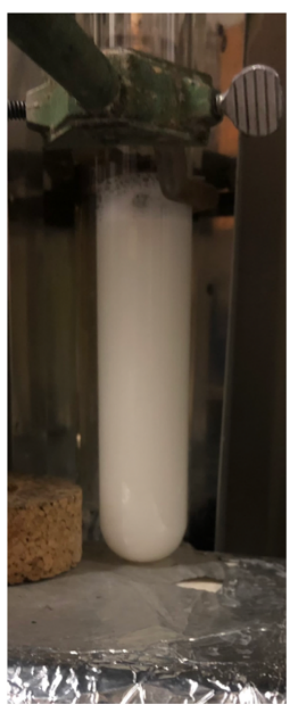

Suspension before irradiation

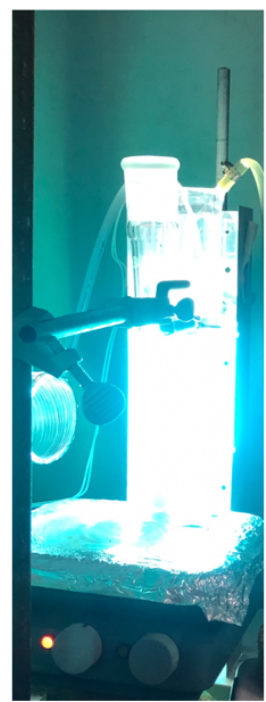

Suspension during irradiation

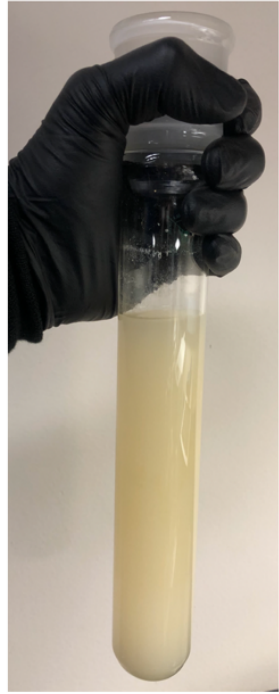

Suspension after irradiation

Note 2: During the reaction, the solids have a tendency to become clumped on the side of the glass.

This aggregation limits surface area and slows reaction progress. To mitigate this problem, the reaction is stopped every $\sim 4-8 h$ and the aggregated solid broken up by swirling the solution rapidly with a glass pipette.

Note 3: It is critical to monitor this reaction by aliquots using ${ }^{1} H$ NMR analysis as reaction times can vary based on how much solid adheres to the glass. Aliquots are collected as follows: $1 \mathrm{~mL}$ of the suspension was removed from the reaction mixture and poured into a culture tube with sat. aq. $\mathrm{NaCl}(2 \mathrm{~mL})$. This mixture was extracted with EtOAc $(2 \times 2 \mathrm{~mL})$. The combined organic layers were dried over $\mathrm{Na}_{2} \mathrm{SO}_{4}$ and then flushed through a plug of silica gel $(\sim 3 \mathrm{~cm})$ with EtOAc $(10 \mathrm{~mL})$. It is important to flush through silica gel prior to collection of NMR spectrum as it removes 
residual SDS. If this is not done, the ${ }^{1} H N M R$ resonances become very broad as a result of the SDS and it is difficult to ascertain reaction conversion.

Note 4: It is critical to maintain rapid stirring so the solids remain suspended throughout the course of the reaction.

Note 5: The 450W Hg lamp produces significant heat. This is mitigated by the jacket of cooling water and fans to circulate warm air out of the box containing the irradiation setup.

Note 6: Bis(arylbromide) 21 is difficult to visualize by TLC analysis. Very concentrated solutions may be visualized on TLC with a $254 \mathrm{~nm}$ handheld UV-lamp.
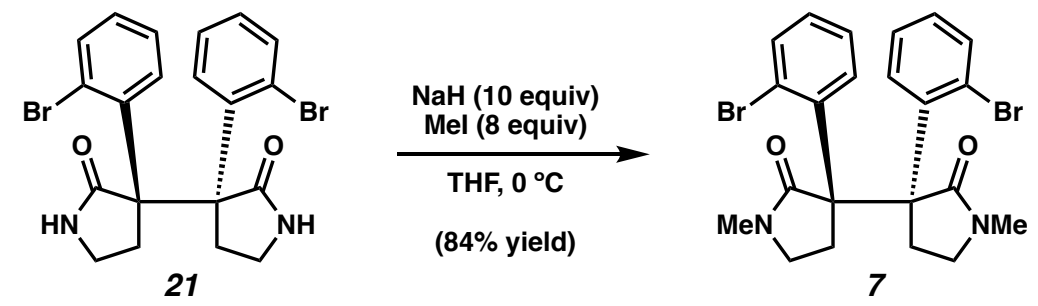

N-Me Bis(arylbromide) 7. THF (2.8 mL) was added to a vial containing neat bis(arylbromide) 21 (40.0 mg, $0.0790 \mathrm{mmol}, 1.00$ equiv) and $\mathrm{NaH}(32 \mathrm{mg}, 60 \%$ dispersion in mineral oil, 0.80 mmol, 10 equiv) and stirred for 5 minutes. The reaction mixture was cooled to $0{ }^{\circ} \mathrm{C}$, MeI $(40 \mu \mathrm{L}$, $0.091 \mathrm{mg}, 0.64 \mathrm{mmol}, 8.1$ equiv) was added dropwise over 1 minute, and then stirred for 45 minutes. The reaction was quenched by pouring into a biphasic mixture of sat. aq. $\mathrm{NH}_{4} \mathrm{Cl}(30 \mathrm{~mL})$ and $\mathrm{CH}_{2} \mathrm{Cl}_{2}(30 \mathrm{~mL})$. The aqueous layer was extracted with $\mathrm{CH}_{2} \mathrm{Cl}_{2}(4 \times 30 \mathrm{~mL})$. The combined organic layers were dried over $\mathrm{Na}_{2} \mathrm{SO}_{4}$ and concentrated under reduced pressure directly onto silica gel $(300 \mathrm{mg})$. The crude product was purified by flash chromatography ( $2 \mathrm{~g}$ silica gel, 9:1 Hexanes:EtOAc $\rightarrow 100 \%$ EtOAc) to give $N-$ Me bis(arylbromide) 7 as a white solid (34 mg, $84 \%$ yield). $N-\mathrm{Me}$ Bis(arylbromide) 7: $\mathrm{R}_{\mathrm{f}} 0.47$ (EtOAc); ${ }^{1} \mathrm{H}$ NMR $\left(600 \mathrm{MHz}, \mathrm{CDCl}_{3}\right) \delta 7.74-7.58$ (m, 
2H), $7.23(\mathrm{dd}, J=7.1,2.7 \mathrm{~Hz}, 2 \mathrm{H}), 7.13-6.96(\mathrm{~m}, 4 \mathrm{H}), 3.59$ (td, $J=9.6,9.1,4.9 \mathrm{~Hz}, 2 \mathrm{H}), 3.52-$ $3.31(\mathrm{~m}, 4 \mathrm{H}), 2.79(\mathrm{~s}, 6 \mathrm{H}), 2.71-2.58(\mathrm{~m}, 2 \mathrm{H}) ;{ }^{13} \mathrm{C} \mathrm{NMR}\left(125 \mathrm{MHz}, \mathrm{CDCl}_{3}\right) \delta$ 173.2, 141.2, 136.1, 135.4, 128.4, 125.4, 124.0, 60.6, 48.4, 30.8, 30.5; HRMS-APCI (m/z) $[\mathrm{M}+\mathrm{H}]^{+}$calcd for $\mathrm{C}_{22} \mathrm{H}_{23} \mathrm{Br}_{2} \mathrm{~N}_{2} \mathrm{O}_{2}^{+}$, 505.0121; found, 505.0104.

Note 1: Bis(arylbromide) 7 is difficult to visualize by TLC analysis. Very concentrated solutions may be visualized on TLC with a $254 \mathrm{~nm}$ handheld UV-lamp.
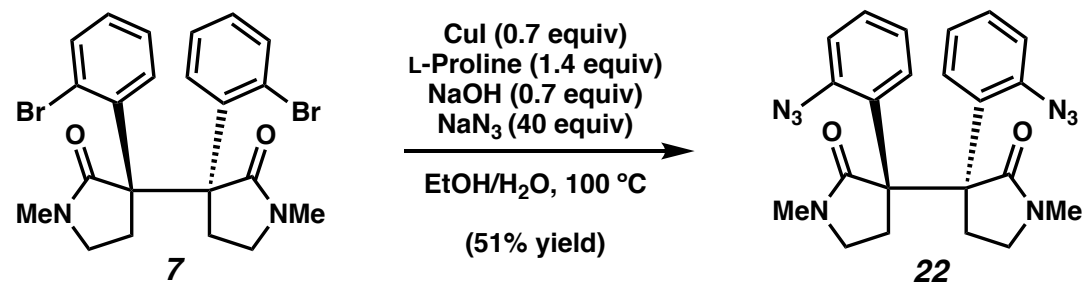

Bis(azide) 22-Optimized Procedure. A dram vial was charged with $N$-Me Bis(arylbromide) 7 ( $8.6 \mathrm{mg}, 0.017 \mathrm{mmol}, 1.00$ equiv) and sodium azide ( $44 \mathrm{mg}, 0.68 \mathrm{mmol}, 40$ equiv) and placed under a flow of $\mathrm{N}_{2}$. Copper(I) iodide (2.26 mg, $0.0119 \mathrm{mmol}, 0.706$ equiv) and L-proline (2.73 $\mathrm{mg}, 0.0237 \mathrm{mmol}, 1.41$ equiv) were charged to the vial which was then evacuated and backfilled with $\mathrm{N}_{2}(3 \mathrm{x})$. DI $\mathrm{H}_{2} \mathrm{O}(0.125 \mathrm{~mL})$, EtOH $(0.385 \mathrm{~mL})$, and $\mathrm{NaOH}(2.0 \mathrm{M}, 0.012 \mathrm{~mL}, 0.71$ equiv) (which had been each been sparged with $\mathrm{N}_{2}$ for $20 \mathrm{~min}$ ) were added by syringe and the reaction was placed in a preheated $100{ }^{\circ} \mathrm{C}$ aluminum heating block and stirred for $20 \mathrm{~h}$. After allowing the reaction to cool to $23{ }^{\circ} \mathrm{C}$, it was poured into a biphasic mixture of aq. $\mathrm{NaOH}(1.0 \mathrm{M}, 5 \mathrm{~mL})$ and $\mathrm{CH}_{2} \mathrm{Cl}_{2}(3 \mathrm{~mL})$. The layers were separated, and the aqueous layer was extracted with $\mathrm{CH}_{2} \mathrm{Cl}_{2}(3 \mathrm{x}$ $4 \mathrm{~mL}$ ). The combined organic layers were dried over $\mathrm{Na}_{2} \mathrm{SO}_{4}$ and concentrated under reduced pressure. After the crude product was further dried under high vacuum for $2 \mathrm{~h}$, it was re-subjected to identical reaction conditions as described above to give bis(azide) 22 (3.4 $\mathrm{mg}, 47 \%$ yield) as a 
cream colored solid without further purification. (Yield determined by ${ }^{1} \mathrm{H}$ QNMR with 1,3,5trimethoxybenzene as the external standard; average yield over two identical runs $(51 \%))$.

Note 1: The CuI used in the optimized reaction conditions was purified from refluxing aq. NaI

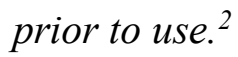
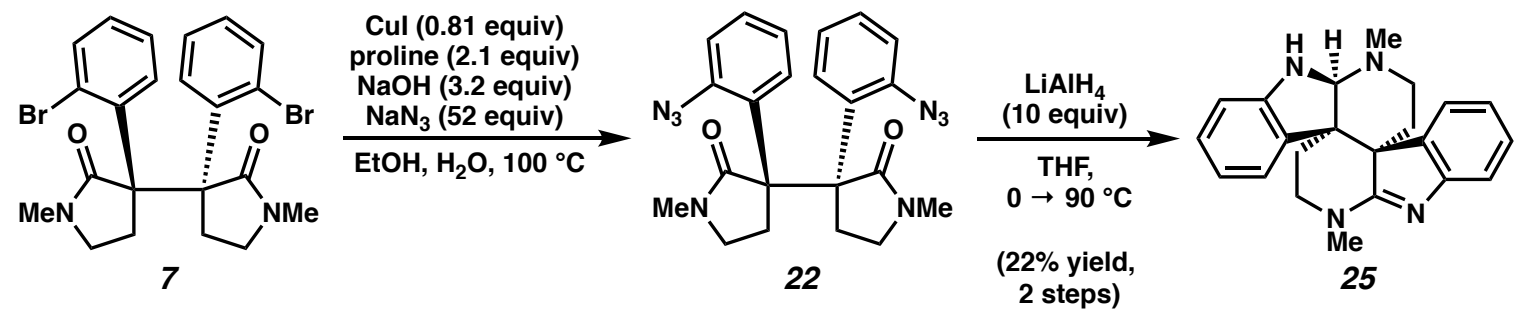

Dihydropsychotriadine 25. A vial was charged with $N$-Me bis(arylbromide) 7 (40.2 mg, 0.0790 mmol, 1.00 equiv), CuI (12.2 mg, $0.0641 \mathrm{mmol}, 0.811$ equiv), L-proline (20.0 mg, $0.173 \mathrm{mmol}$, 2.18 equiv), $\mathrm{NaOH}$ (10.1 mg, $0.252 \mathrm{mmol}, 3.19$ equiv), and $\mathrm{NaN}_{3}$ (226 mg, 4.09 mmol, 51.8 equiv) and then taken into a glovebox under $\mathrm{N}_{2}$ atmosphere. EtOH $(1.4 \mathrm{~mL})$ and $\mathrm{DI}_{2} \mathrm{O}(0.6 \mathrm{~mL})$ that had been sparged for 20 minutes with argon were added via syringe and the vial was sealed with a Teflon screwcap, removed from the glovebox, and placed in an aluminum block preheated to $100{ }^{\circ} \mathrm{C}$. The reaction was stirred at $100{ }^{\circ} \mathrm{C}$ for $24 \mathrm{~h}$, cooled to $23{ }^{\circ} \mathrm{C}$, and then diluted with aq. $\mathrm{NaOH}(0.20 \mathrm{M}, 4 \mathrm{~mL})$. The reaction mixture was washed with $\mathrm{CH}_{2} \mathrm{Cl}_{2}(3 \times 3 \mathrm{~mL})$ and the combined organic layers were dried over $\mathrm{Na}_{2} \mathrm{SO}_{4}$ and concentrated under reduced pressure directly onto silica gel $(400 \mathrm{mg})$. The crude product was purified by flash column chromatography $(2 \mathrm{~g}$ silica gel, 6:4 Hexanes:EtOAc $\rightarrow$ 1:1 Hexanes:EtOAc) to give semi-pure bis(arylazide) 22 which was used without further purification in the next step.

The semipure bis(arylazide) 22 from the previous step (24 mg) was dissolved in THF (3.0 $\mathrm{mL}$ ) and cooled to $0{ }^{\circ} \mathrm{C}$. To the stirring mixture was added $\mathrm{LiAlH}_{4}(24 \mathrm{mg}, 0.63 \mathrm{mmol}, 10$ equiv) 
in one portion and then sealed with a Teflon screwcap. The mixture was stirred at $0{ }^{\circ} \mathrm{C}$ for $20 \mathrm{~min}$, then warmed to $23{ }^{\circ} \mathrm{C}$ and stirred for another $20 \mathrm{~min}$. The reaction mixture was then placed in an aluminum block preheated to $90{ }^{\circ} \mathrm{C}$ and stirred for $1 \mathrm{~h}$. The reaction was then cooled to $23{ }^{\circ} \mathrm{C}$, diluted with EtOAc $(1 \mathrm{~mL})$, aq. $\mathrm{NaOH}(0.20 \mathrm{M}, 2 \mathrm{~mL})$, and $\mathrm{CH}_{2} \mathrm{Cl}_{2}(3 \mathrm{~mL})$. The layers were separated and the aqueous layer was extracted with $\mathrm{CH}_{2} \mathrm{Cl}_{2}(2 \times 3 \mathrm{~mL})$. The combined organic layers were dried over $\mathrm{Na}_{2} \mathrm{SO}_{4}$ and concentrated under reduced pressure. The crude mixture was purified via preparative thin layer chromatography $\left(3 \% \mathrm{MeOH}\right.$ in $\mathrm{CH}_{2} \mathrm{Cl}_{2}$ saturated with $\left.\mathrm{NH}_{3}\right)$ to afford dihydropsychotriadine $25(6.0 \mathrm{mg}, 22 \%$ yield, two steps). Crystals suitable for X-ray diffraction studies (CCDC 1999795) were obtained using slow evaporation from $\mathrm{CDCl}_{3}$ over 3 days. Dehydropsychotriadine 25: $\mathrm{R}_{\mathrm{f}} 0.19\left(5 \% \mathrm{MeOH}\right.$ in $\mathrm{CH}_{2} \mathrm{Cl}_{2}$ saturated with $\left.\mathrm{NH}_{3}\right) ;{ }^{1} \mathrm{H} \mathrm{NMR}$ $\left(500 \mathrm{MHz}, \mathrm{CDCl}_{3}\right) \delta 7.79(\mathrm{~d}, J=7.5 \mathrm{~Hz}, 1 \mathrm{H}), 7.07(\mathrm{~d}, J=7.7 \mathrm{~Hz}, 1 \mathrm{H}), 6.98(\mathrm{t}, J=7.5 \mathrm{~Hz}, 1 \mathrm{H})$, $6.83(\mathrm{t}, J=7.6 \mathrm{~Hz}, 1 \mathrm{H}), 6.64(\mathrm{~d}, J=7.5 \mathrm{~Hz}, 1 \mathrm{H}), 6.58(\mathrm{dt}, J=7.5,3.6 \mathrm{~Hz}, 2 \mathrm{H}), 6.39(\mathrm{t}, J=7.4 \mathrm{~Hz}$, 1H), $4.54(\mathrm{~s}, 1 \mathrm{H}), 4.22$ (br s, $1 \mathrm{H}), 3.80(\mathrm{dt}, J=12.4,6.3 \mathrm{~Hz}, 1 \mathrm{H}), 3.48(\mathrm{dt}, J=13.1,6.6 \mathrm{~Hz}, 1 \mathrm{H})$, $3.31-3.17(\mathrm{~m}, 4 \mathrm{H}), 2.62(\mathrm{~d}, J=10.1 \mathrm{~Hz}, 5 \mathrm{H}), 2.29(\mathrm{td}, J=12.8,4.2 \mathrm{~Hz}, 1 \mathrm{H}), 2.25-2.16(\mathrm{~m}$, 1H), $1.21(\mathrm{dd}, J=13.3,2.8 \mathrm{~Hz}, 1 \mathrm{H}) ;{ }^{13} \mathrm{C} \mathrm{NMR}\left(125 \mathrm{MHz}, \mathrm{CDCl}_{3}\right) \delta 177.8,154.0,148.0,139.2$, $134.2,128.1,127.6,123.9,122.0,120.4,119.8,116.5,110.8,86.1,56.0,49.5,46.2,44.3,42.7$, 38.7, 33.2, 33.1; HRMS-APCI (m/z) $[\mathrm{M}+\mathrm{H}]^{+}$calcd for $\mathrm{C}_{22} \mathrm{H}_{25} \mathrm{~N}_{4}{ }^{+}, 345.2074$; found, 345.2079.

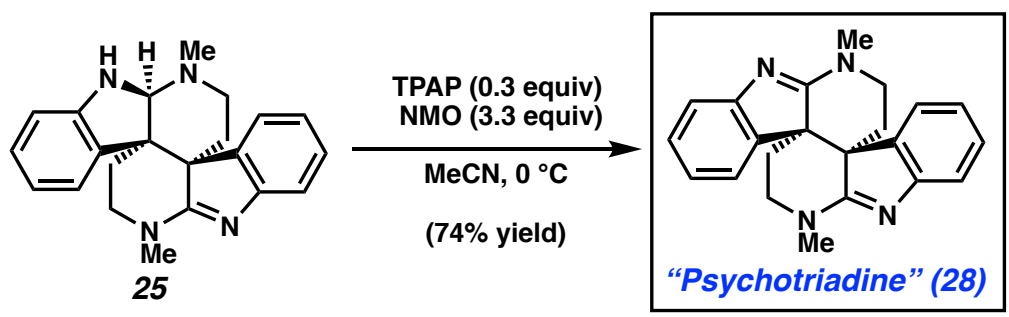


Psychotriadine 28. A stock solution of TPAP (4.2 mg, $0.010 \mathrm{mmol}, 0.91$ equiv) and NMO (12.3 $\mathrm{mg}, 0.105 \mathrm{mmol}, 10.0$ equiv) in $\mathrm{MeCN}(1.80 \mathrm{~mL})$ was prepared. To a separate vial containing dehydropsychotriadine 25 (3.9 mg, $0.011 \mathrm{mmol}, 1.0$ equiv) dissolved in $\mathrm{MeCN}(1.10 \mathrm{~mL})$ at $0{ }^{\circ} \mathrm{C}$ was added $0.600 \mathrm{~mL}$ of the aforementioned stock solution dropwise over 1 minute. The reaction was stirred at $0{ }^{\circ} \mathrm{C}$ for $1 \mathrm{~h}$ before being diluted with $\mathrm{CH}_{2} \mathrm{Cl}_{2}$ saturated with $\mathrm{NH}_{3}(3 \mathrm{~mL})$. The mixture was flushed through a silica plug $(2 \mathrm{~cm})$, then the silica plug was rinsed with $\mathrm{CH}_{2} \mathrm{Cl}_{2}$ saturated with $\mathrm{NH}_{3}(6 \mathrm{~mL})$. The mixture was then concentrated under reduced pressure and the crude mixture was purified via preparative thin layer chromatography $\left(3 \% \mathrm{MeOH}\right.$ in $\mathrm{CH}_{2} \mathrm{Cl}_{2}$ saturated with $\mathrm{NH}_{3}$ ) to afford pysochotriadine 28 as a white solid (2.9 $\mathrm{mg}, 74 \%$ yield). Psychotriadine 28: $\mathrm{R}_{\mathrm{f}} 0.22\left(5 \% \mathrm{MeOH}\right.$ in $\mathrm{CH}_{2} \mathrm{Cl}_{2}$ saturated with $\left.\mathrm{NH}_{3}\right) ;{ }^{1} \mathrm{H} \mathrm{NMR}(600 \mathrm{MHz}$, $\left.\mathrm{CDCl}_{3}\right) \delta 7.24(\mathrm{~d}, J=7.7 \mathrm{~Hz}, 2 \mathrm{H}), 7.09(\mathrm{ddd}, J=7.7,6.9,1.9 \mathrm{~Hz}, 2 \mathrm{H}), 6.72-6.56(\mathrm{~m}, 4 \mathrm{H}), 3.59$ $-3.47(\mathrm{~m}, 4 \mathrm{H}), 3.22(\mathrm{~s}, 6 \mathrm{H}), 2.90(\mathrm{ddd}, J=14.2,11.9,7.3 \mathrm{~Hz}, 2 \mathrm{H}), 1.49(\mathrm{ddd}, J=14.2,5.1,1.6$ $\mathrm{Hz}, 2 \mathrm{H}) ;{ }^{13} \mathrm{C} \mathrm{NMR}\left(125 \mathrm{MHz}, \mathrm{CDCl}_{3}\right)$ 176.8, 154.1, 136.6, 128.7, 121.6, 120.5, 117.7, 51.5, 49.4, 38.2, 33.3; HRMS-APCI (m/z) [M + H] $]^{+}$calcd for $\mathrm{C}_{22} \mathrm{H}_{23} \mathrm{~N}_{4}{ }^{+}, 343.1932$; found, 343.1920. 
Supplementary Table 1. Comparison of ${ }^{13} \mathrm{C}$ NMR Data for Natural ${ }^{3}$ vs. Synthetic Psychotriadine.

\begin{tabular}{|c|c|}
\hline $\begin{array}{c}\text { Natural Psychotriadine } \\
\text { (From Sample Provided by L. Verotta) } \\
{ }^{13} \mathrm{C}, 500 \mathrm{MHz}, \mathrm{CDCl}_{3}\end{array}$ & $\begin{array}{l}\text { Synthetic Psychotriadine } \\
{ }^{13} \mathrm{C}, 500 \mathrm{MHz}, \mathrm{CDCl}_{3}\end{array}$ \\
\hline 176.8 & 176.8 \\
\hline 154.1 & 154.1 \\
\hline 136.6 & 136.6 \\
\hline 128.7 & 128.7 \\
\hline 121.5 & 121.6 \\
\hline 120.5 & 120.5 \\
\hline 117.6 & 117.7 \\
\hline 51.5 & 51.5 \\
\hline 49.4 & 49.4 \\
\hline 38.2 & 38.2 \\
\hline 33.3 & 33.3 \\
\hline
\end{tabular}




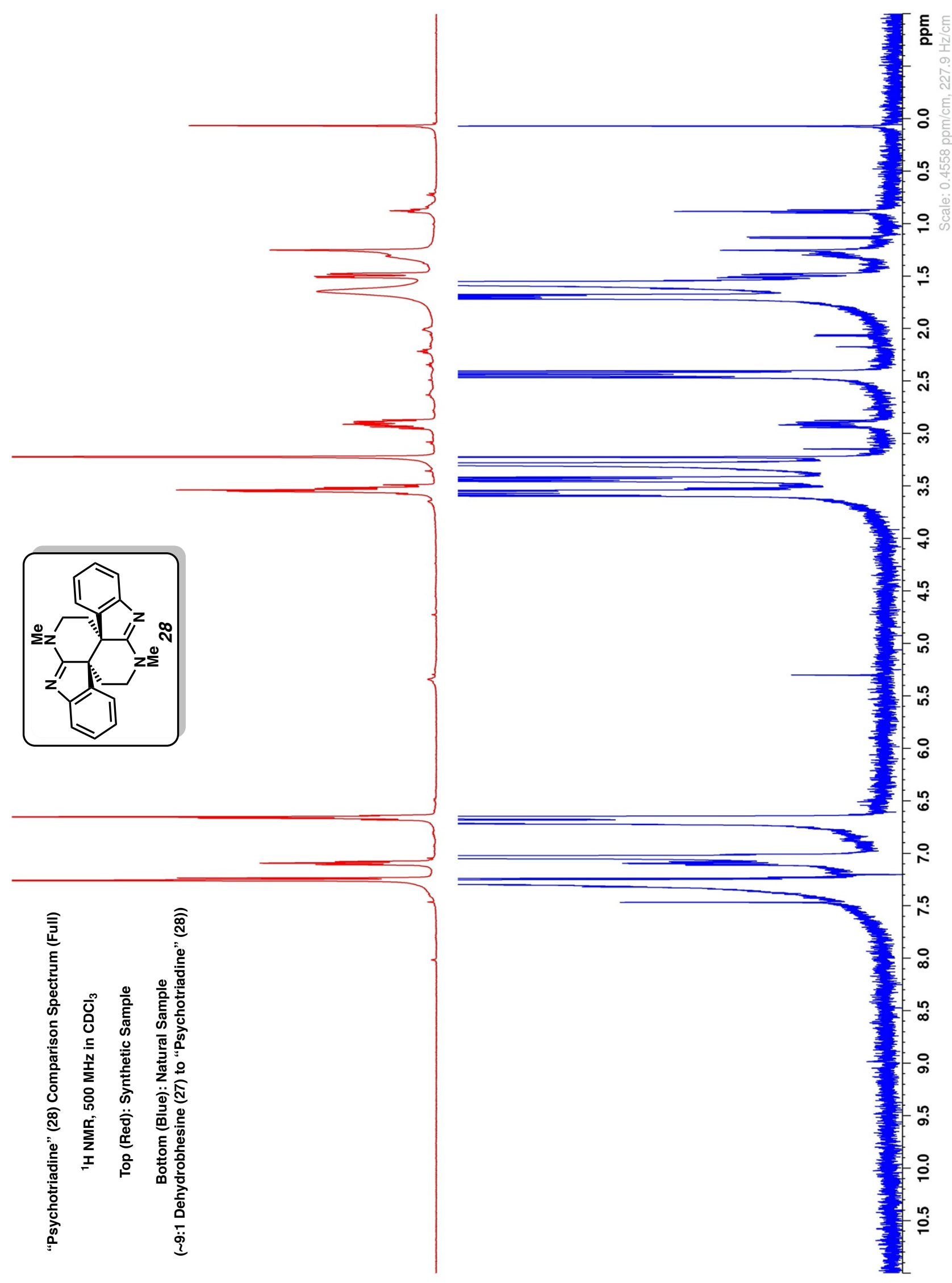



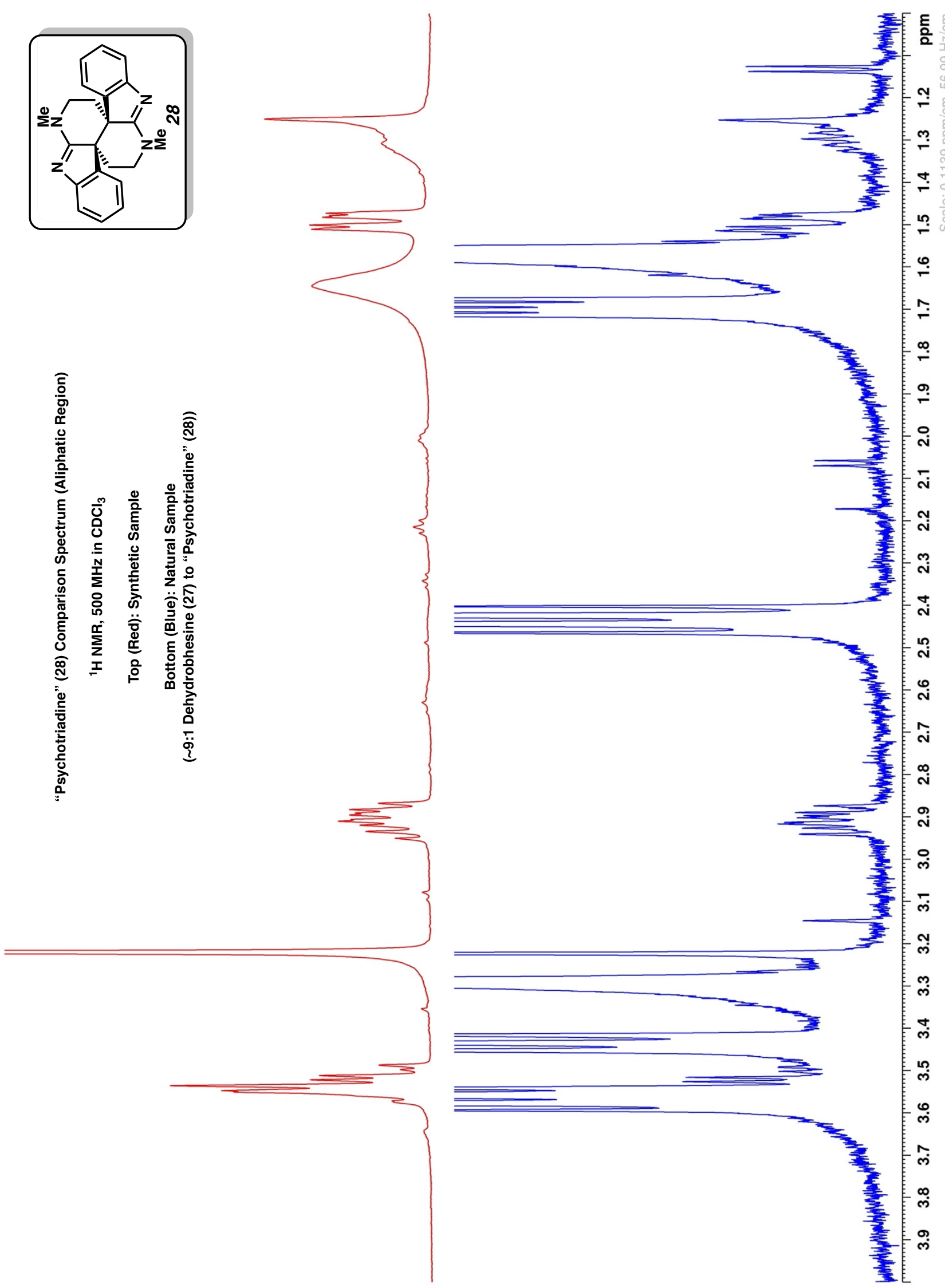


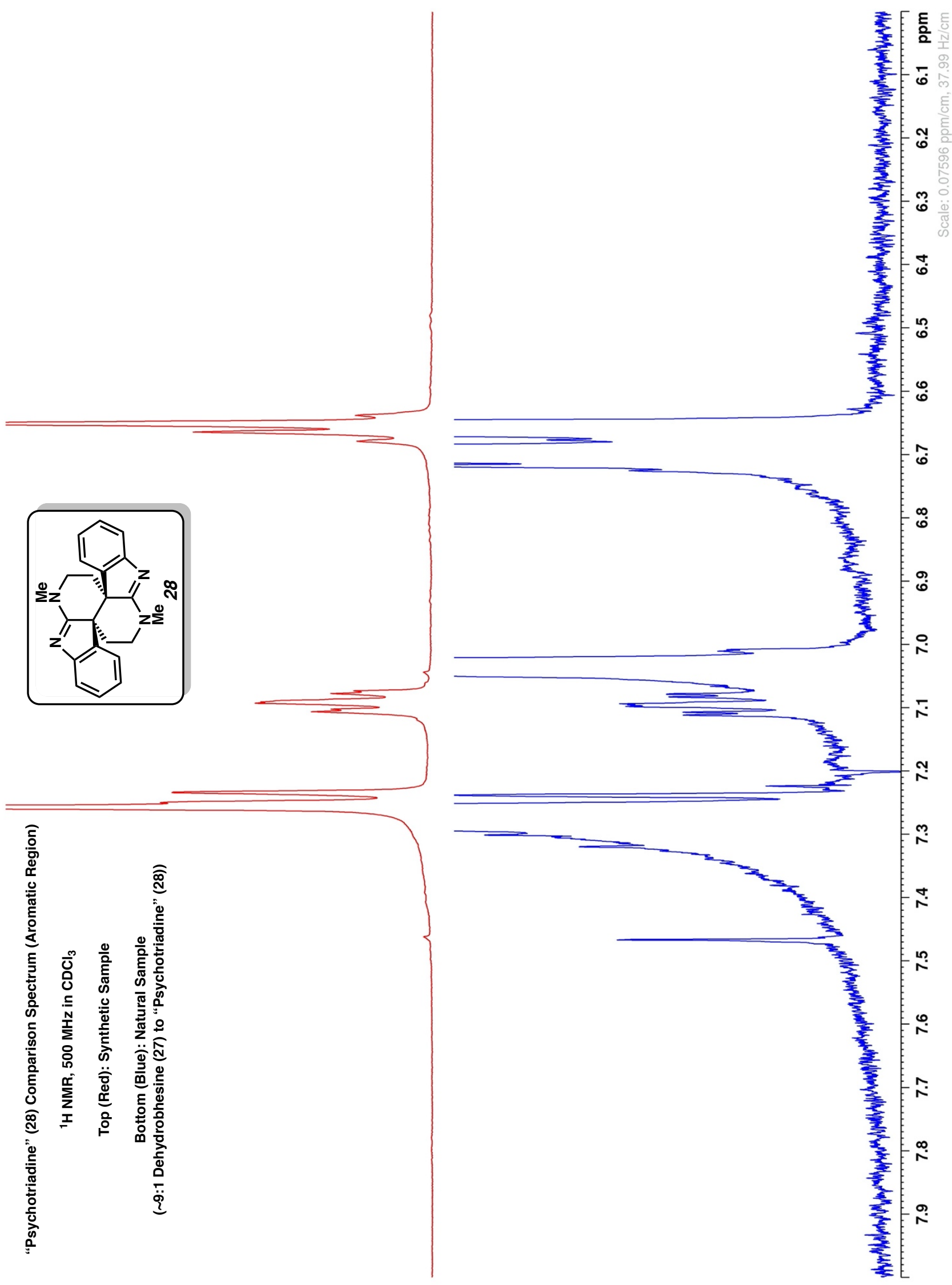




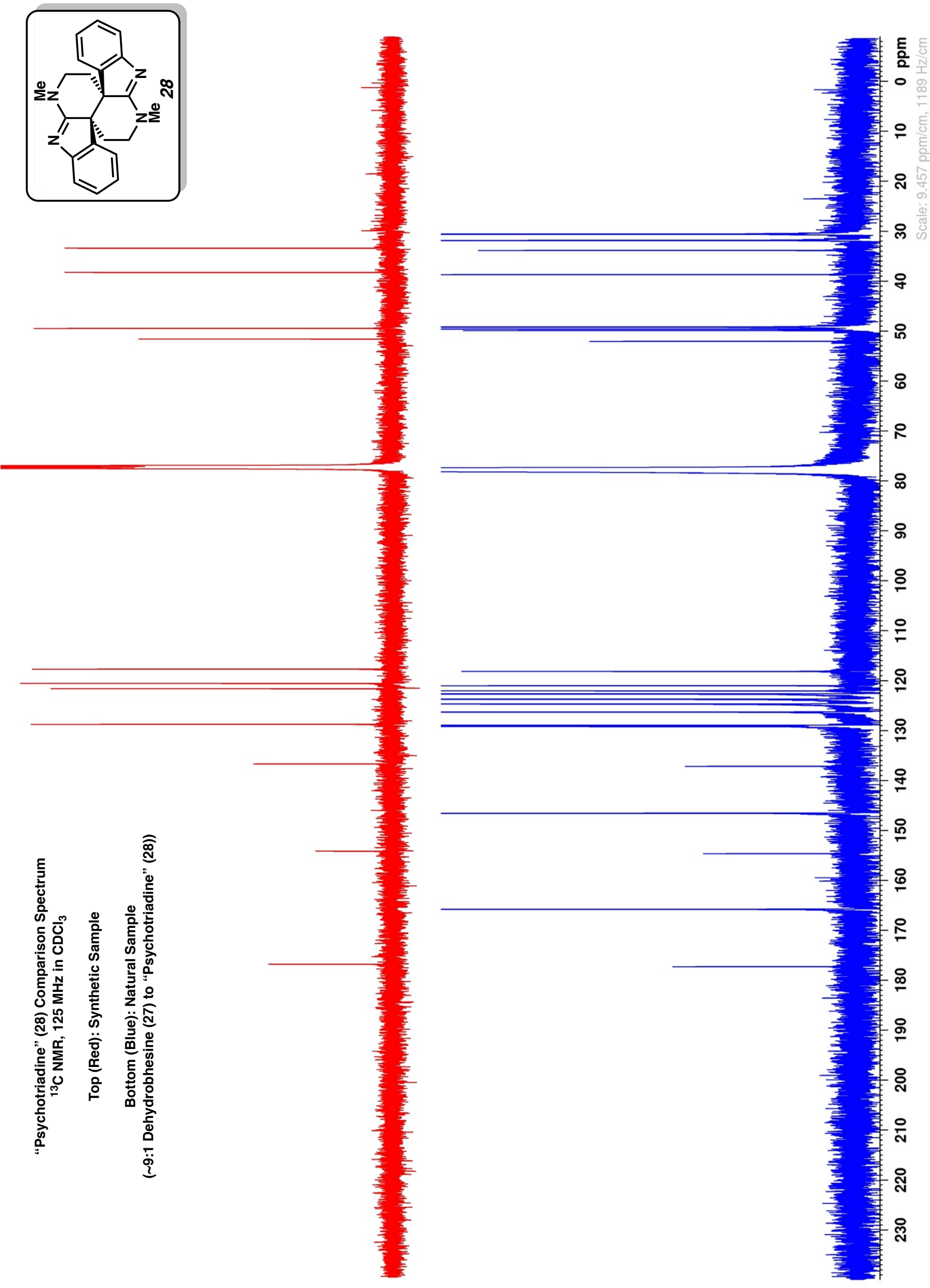




\section{H NMR Spectra:}



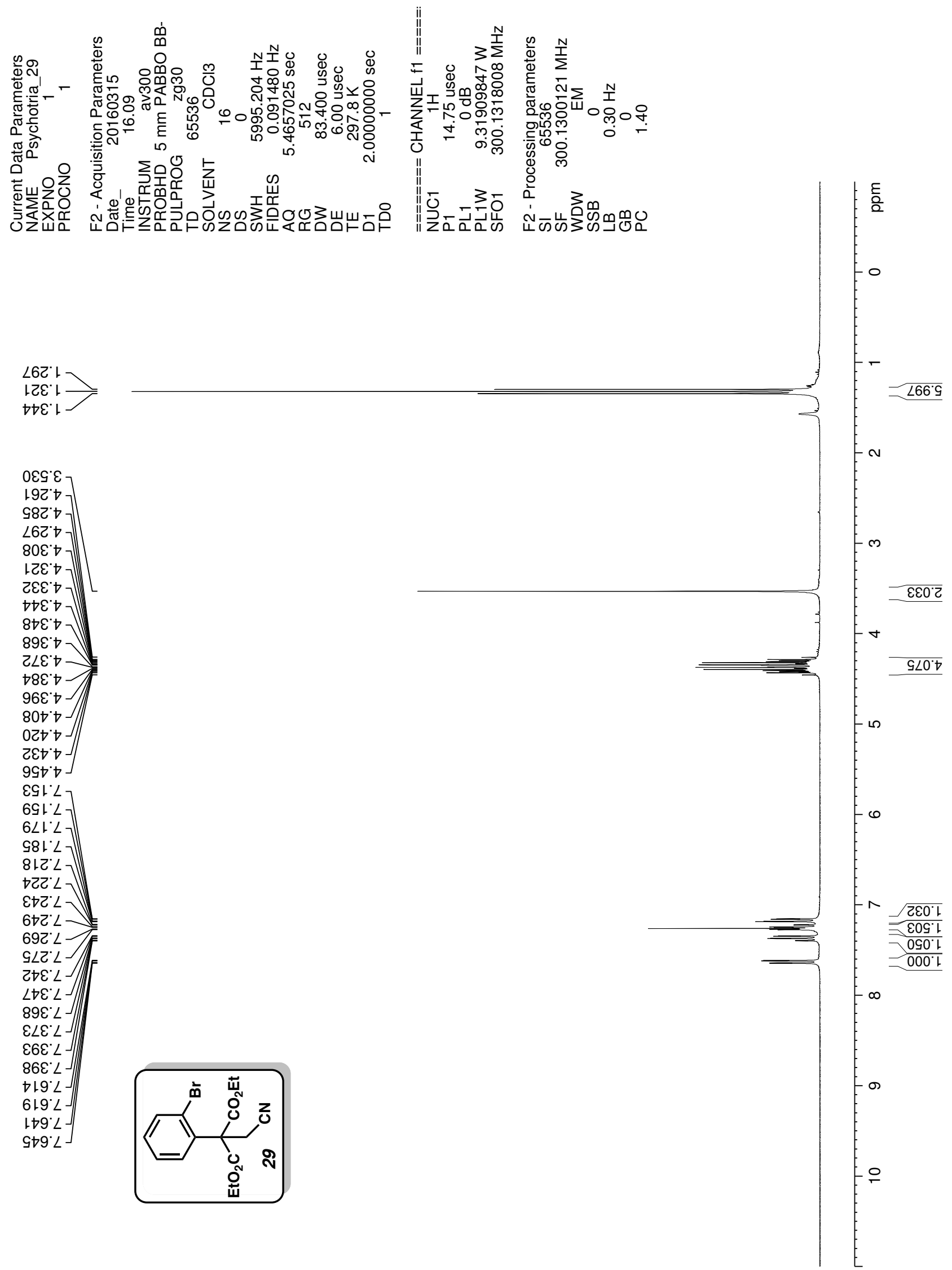


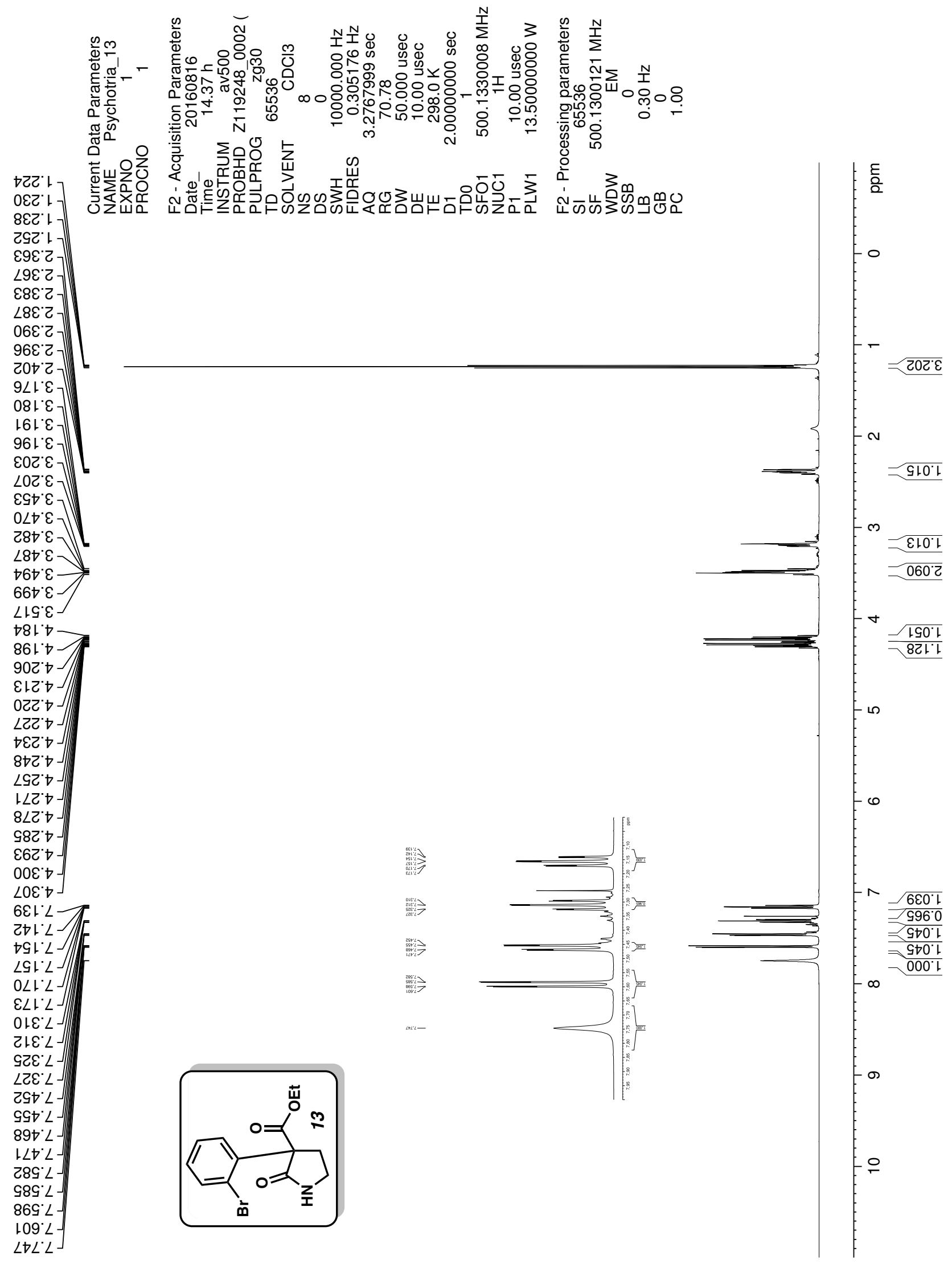




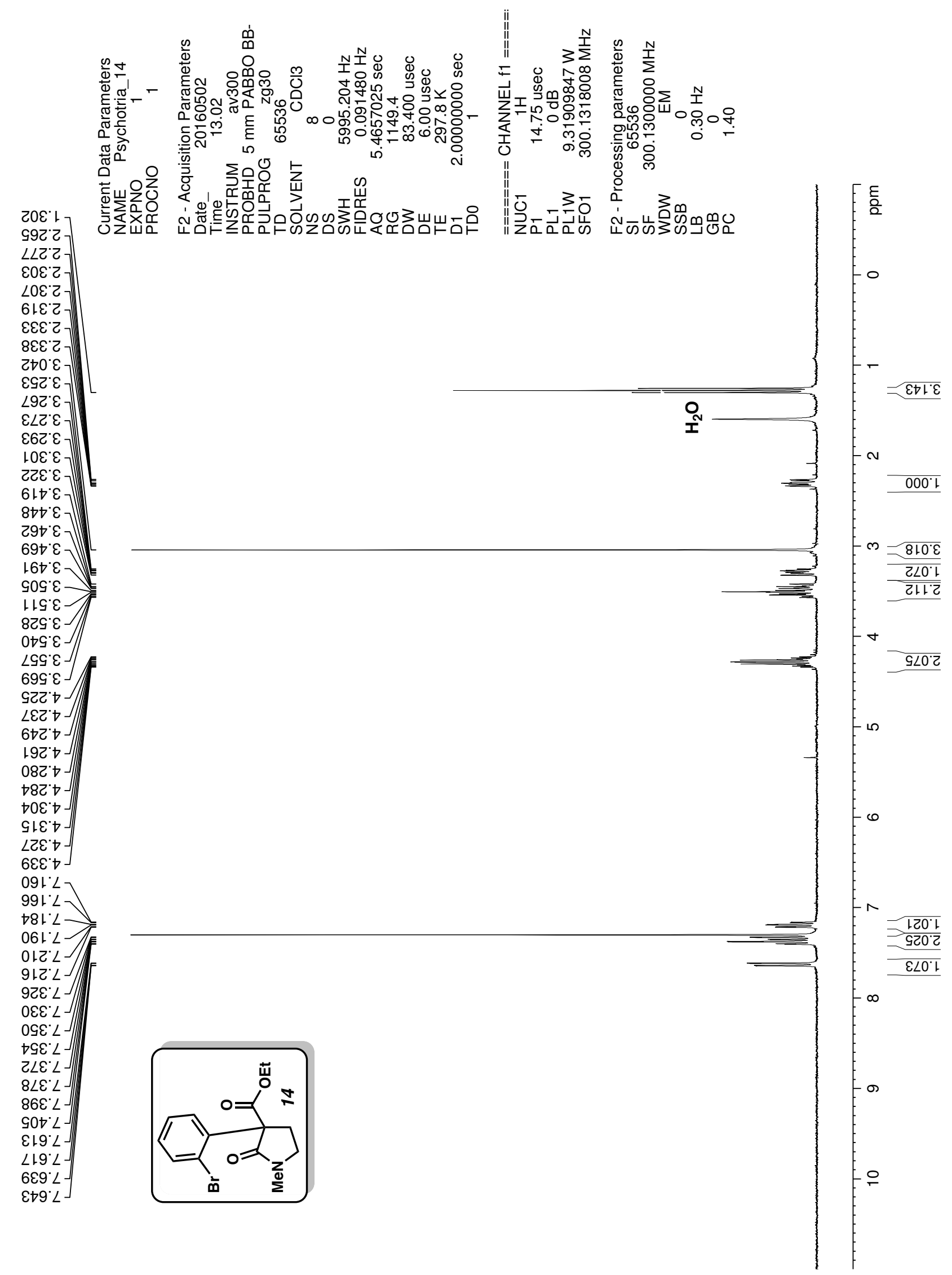




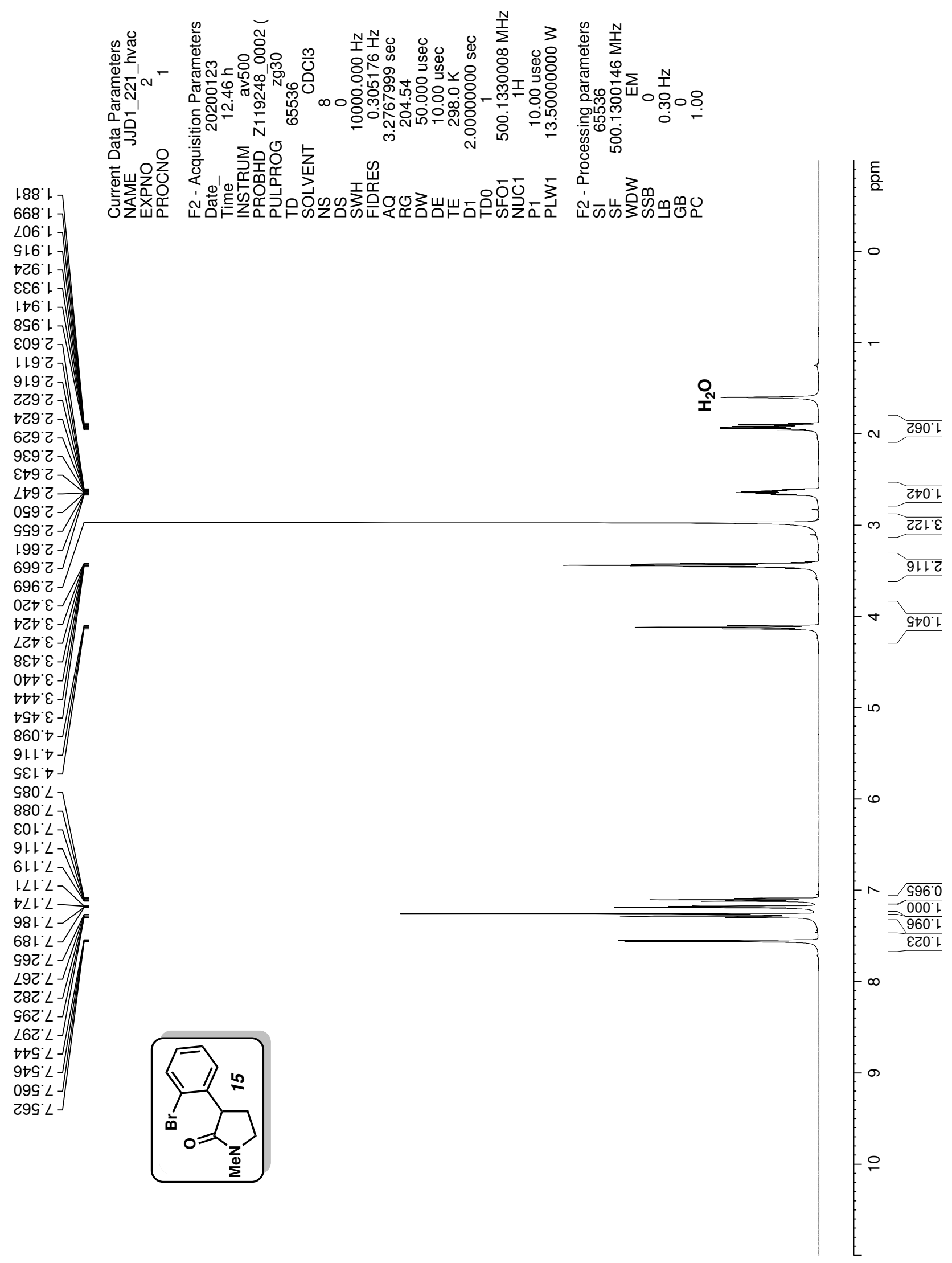



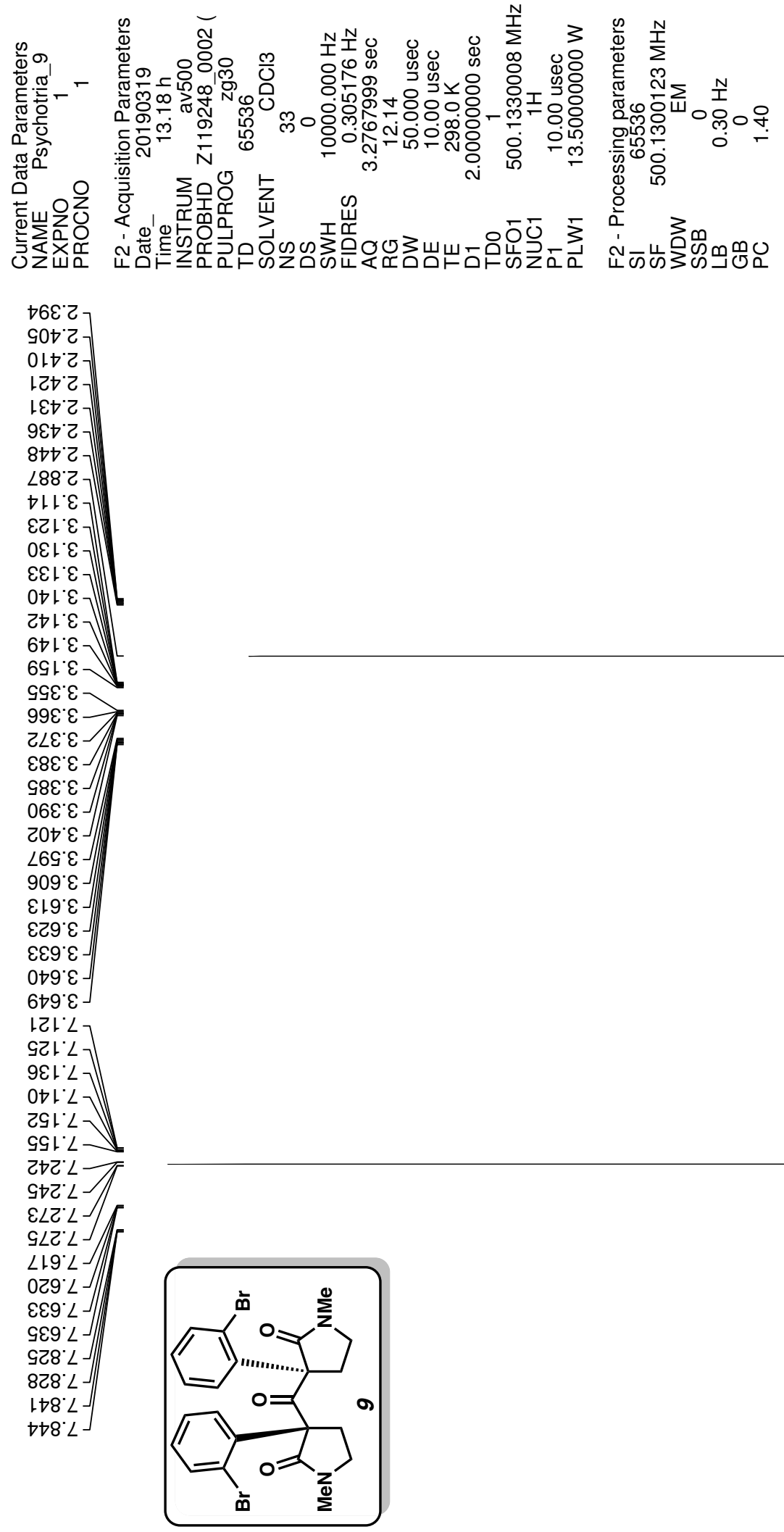


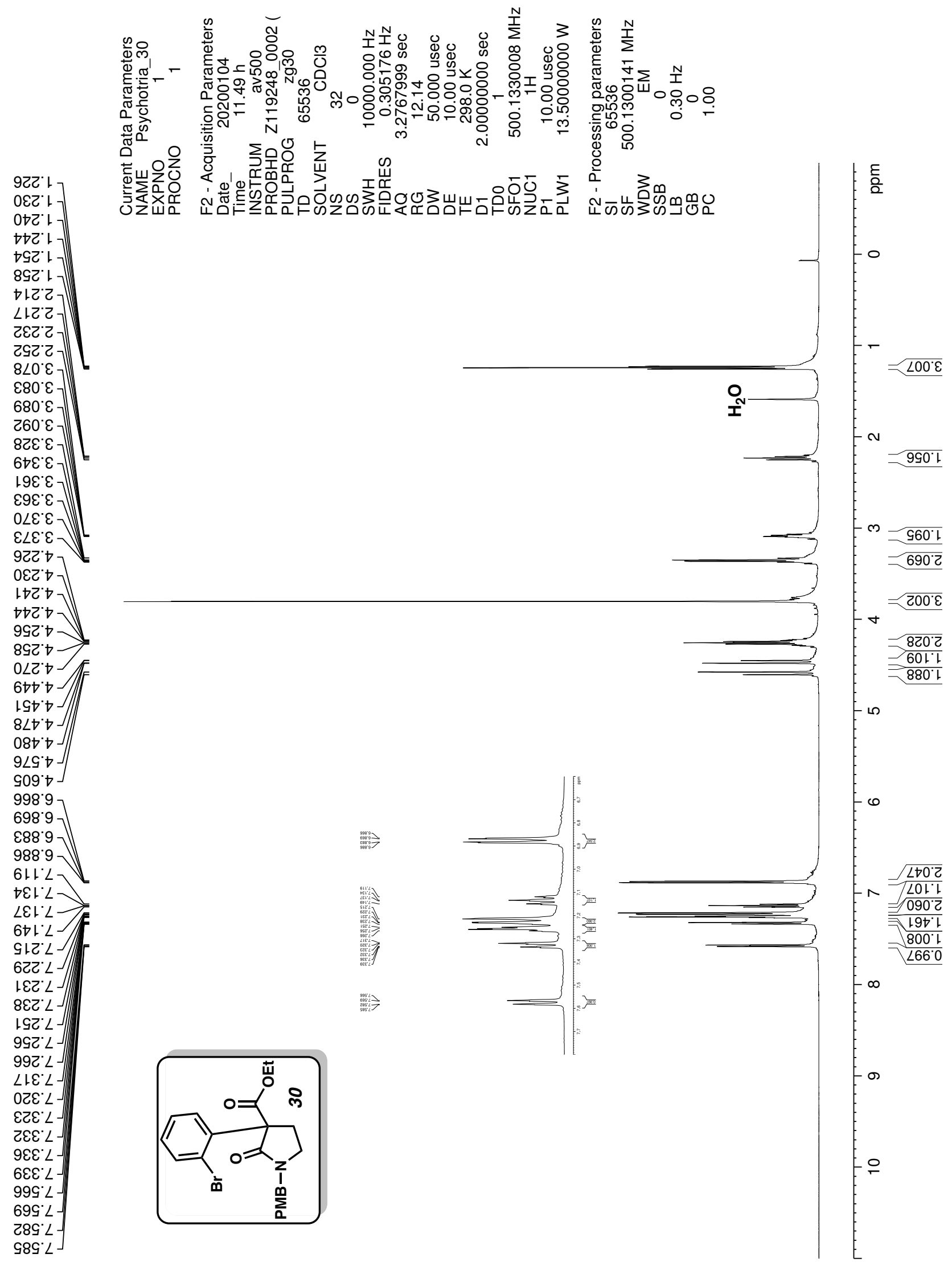




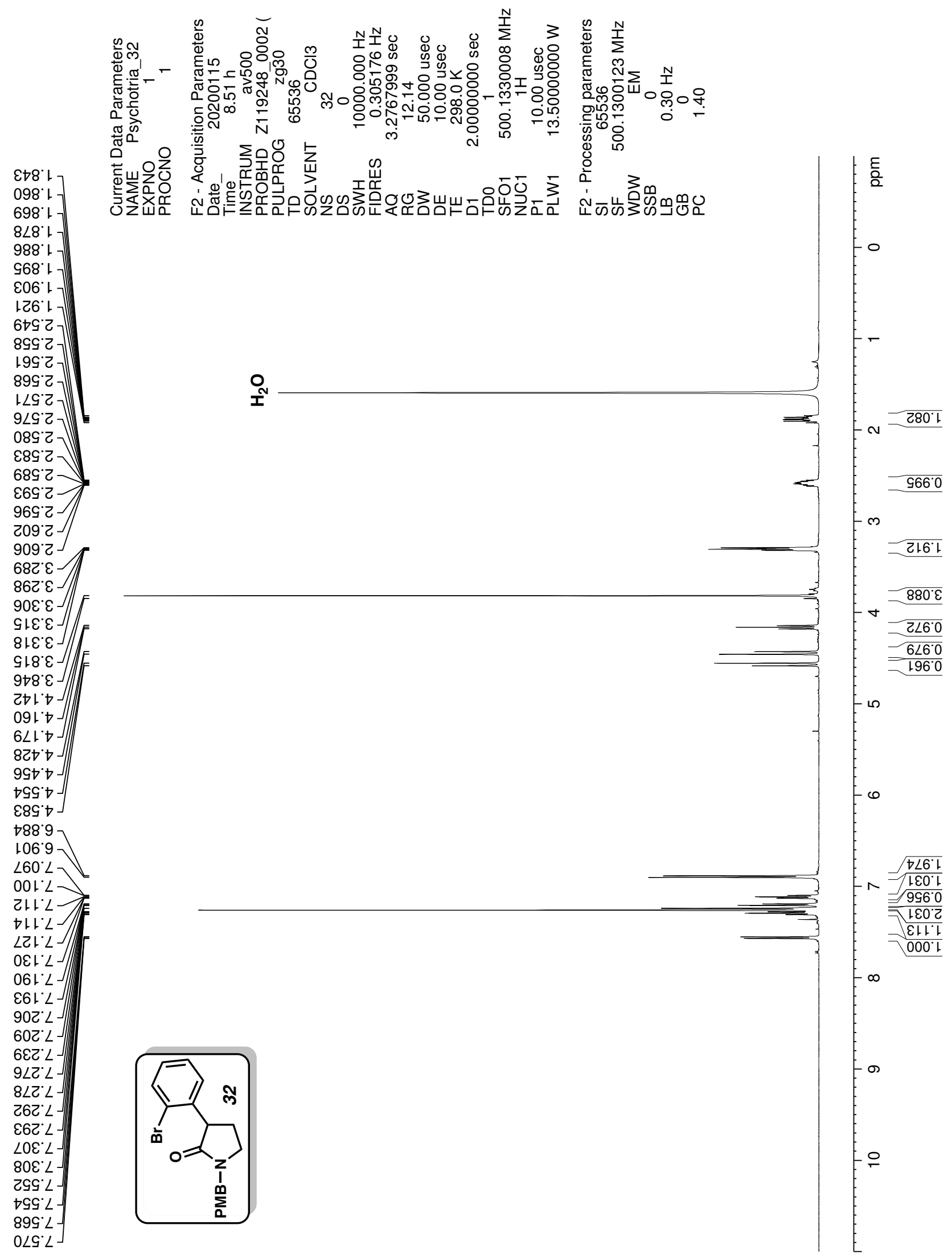



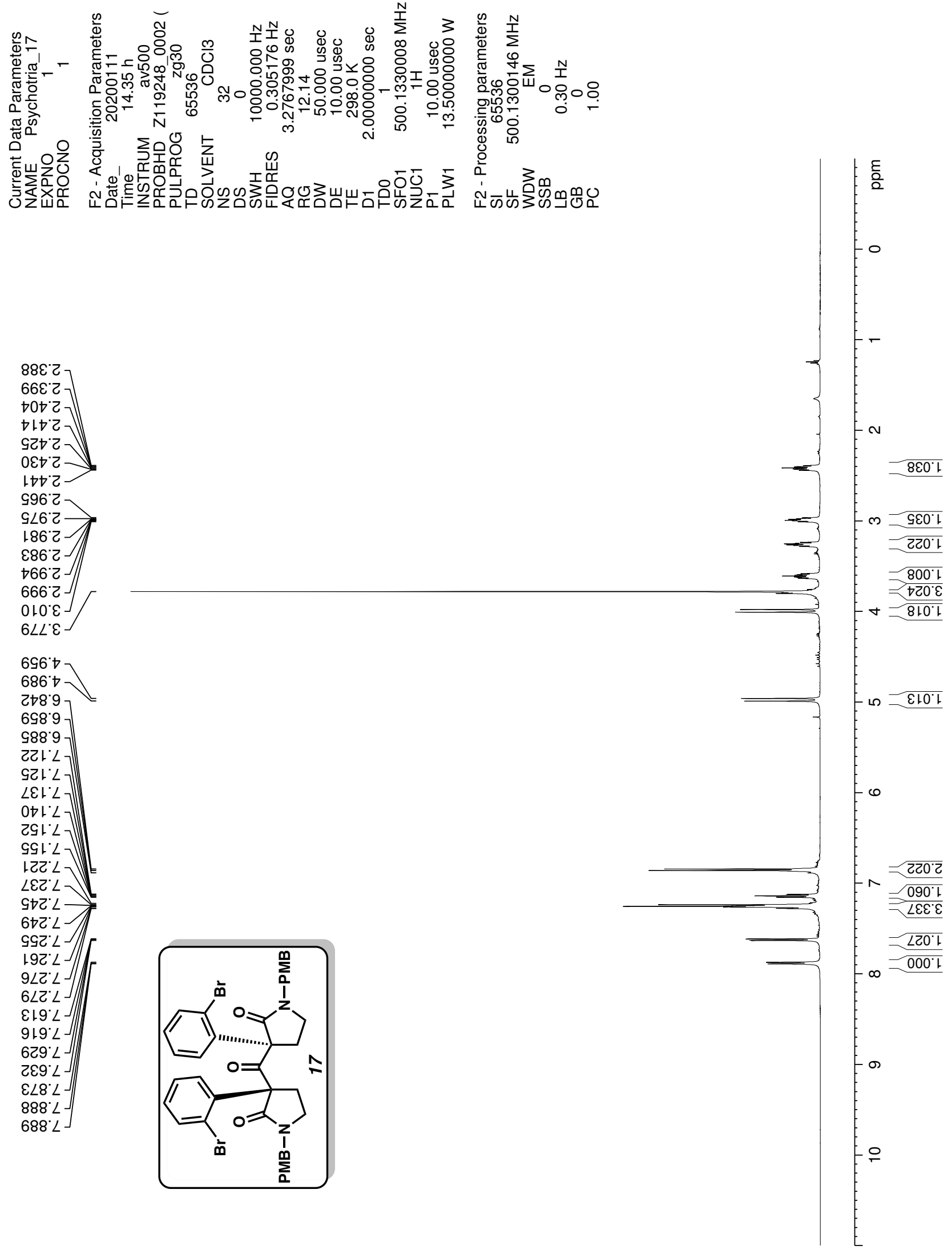

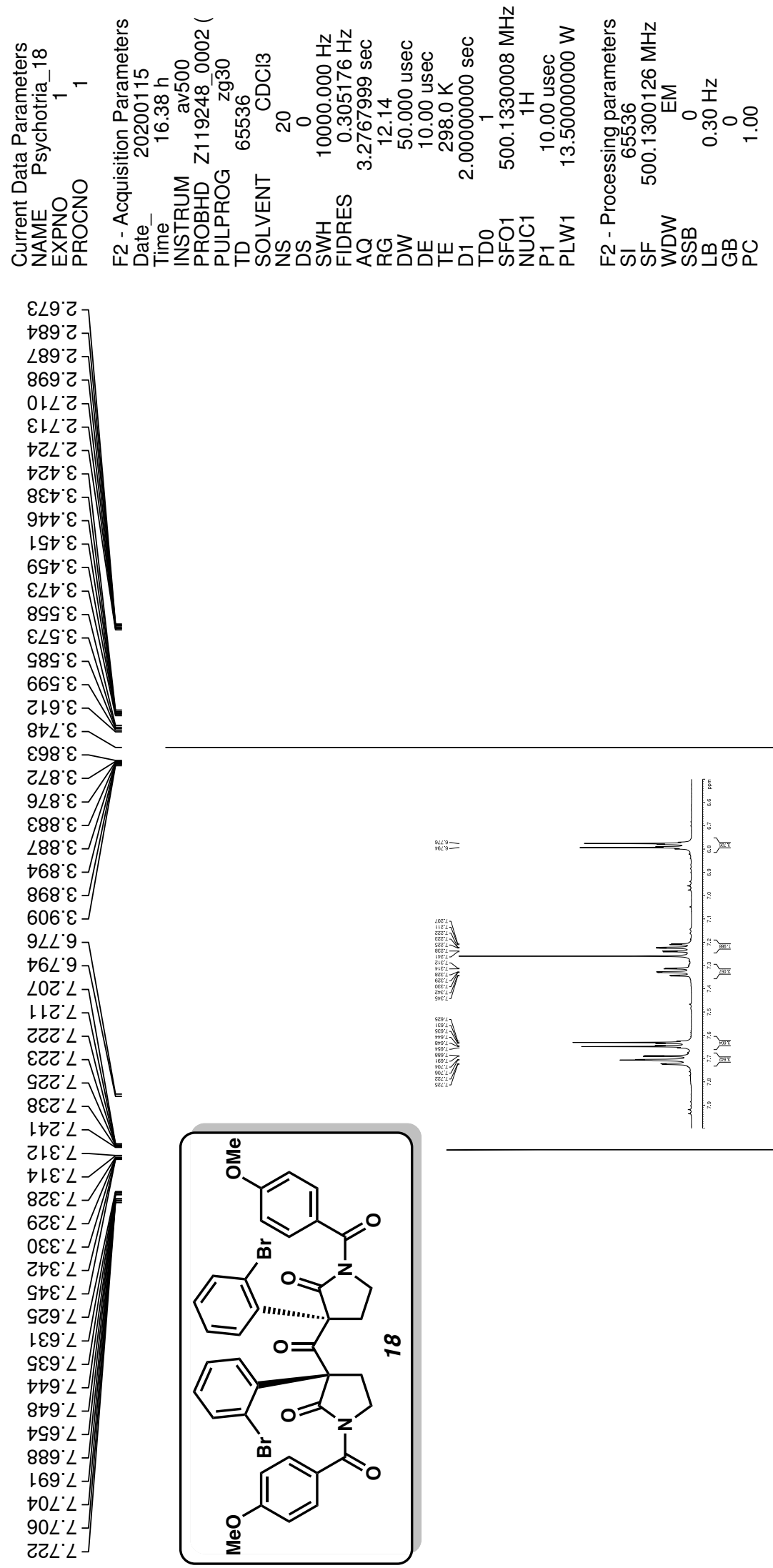


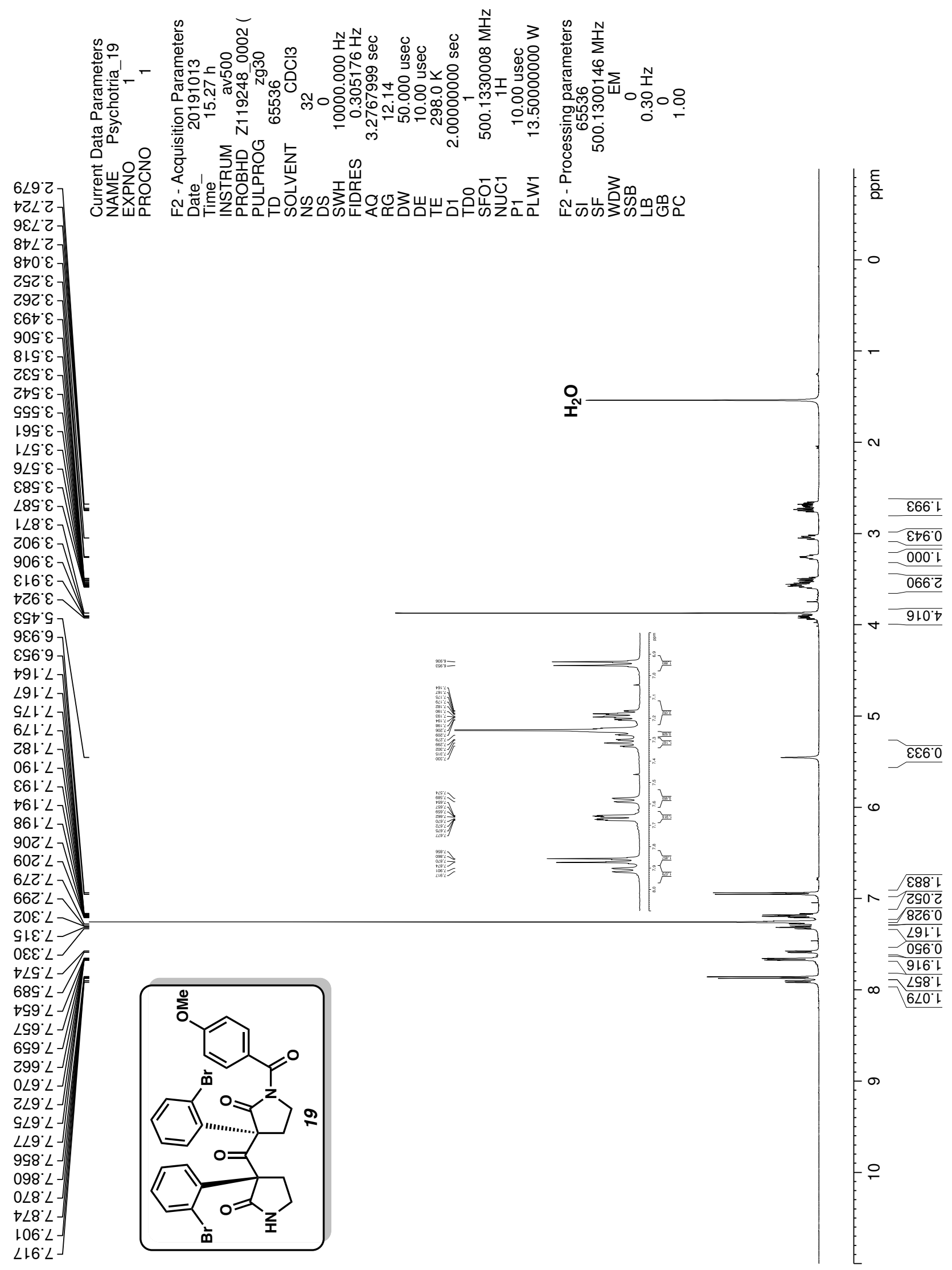



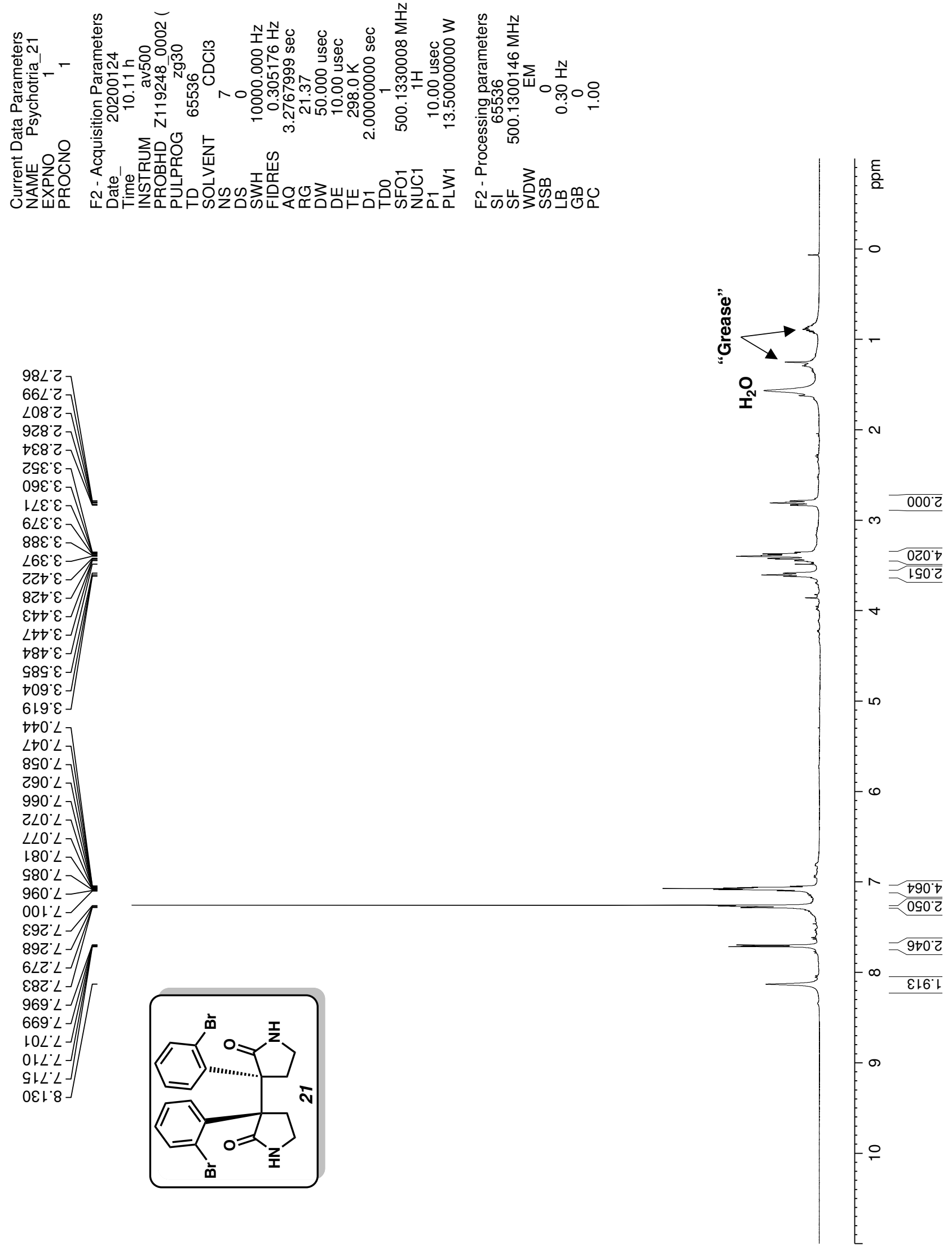

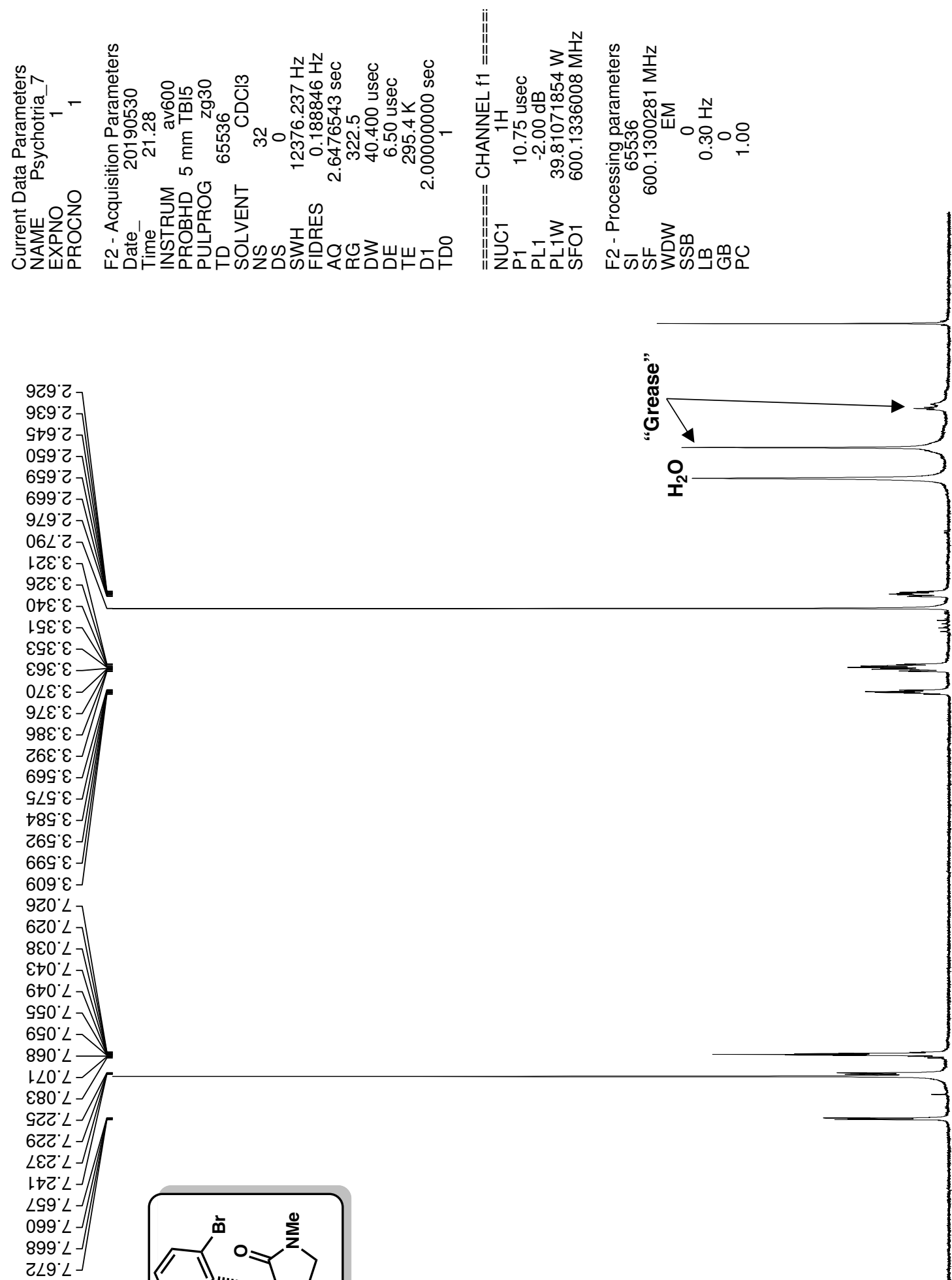


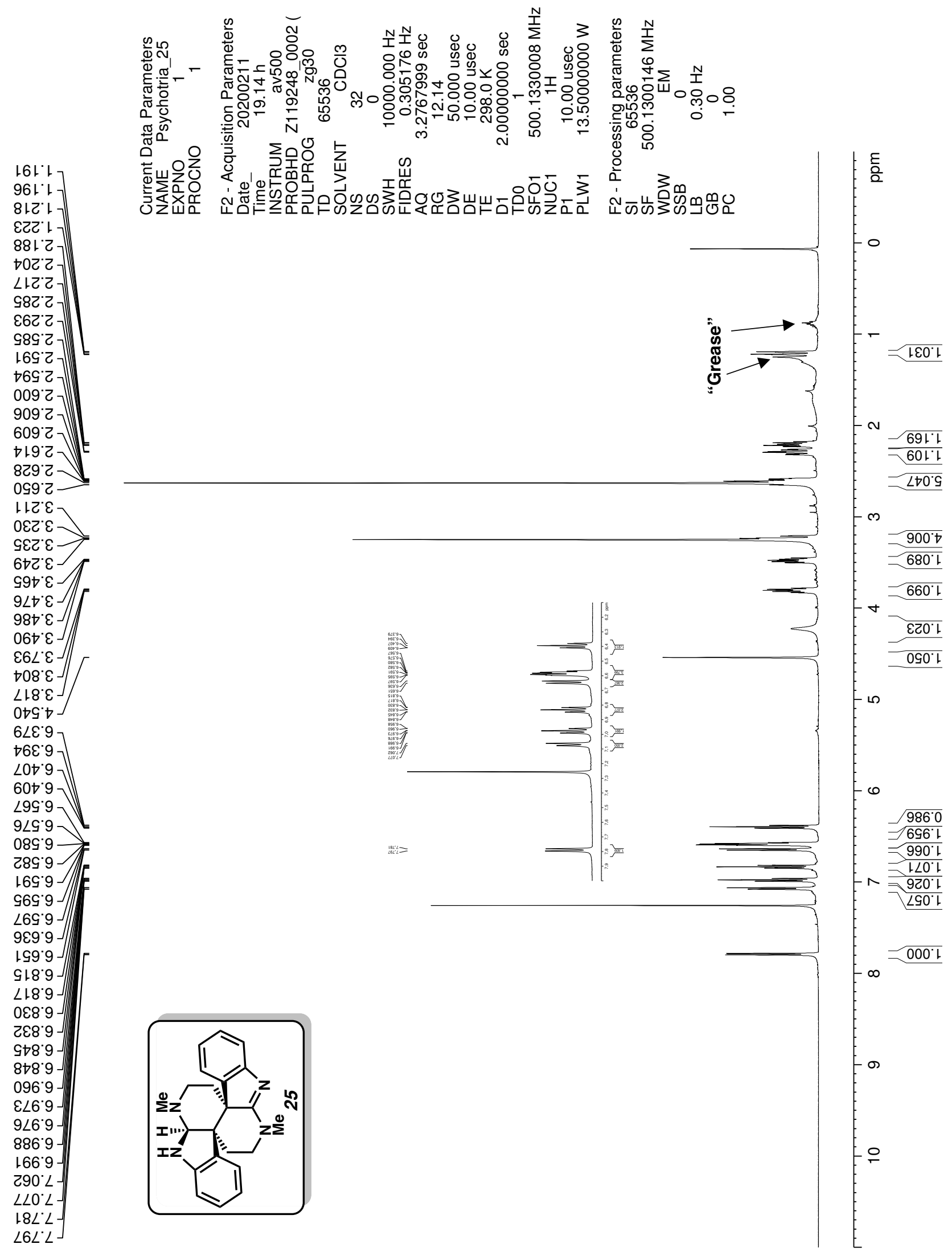



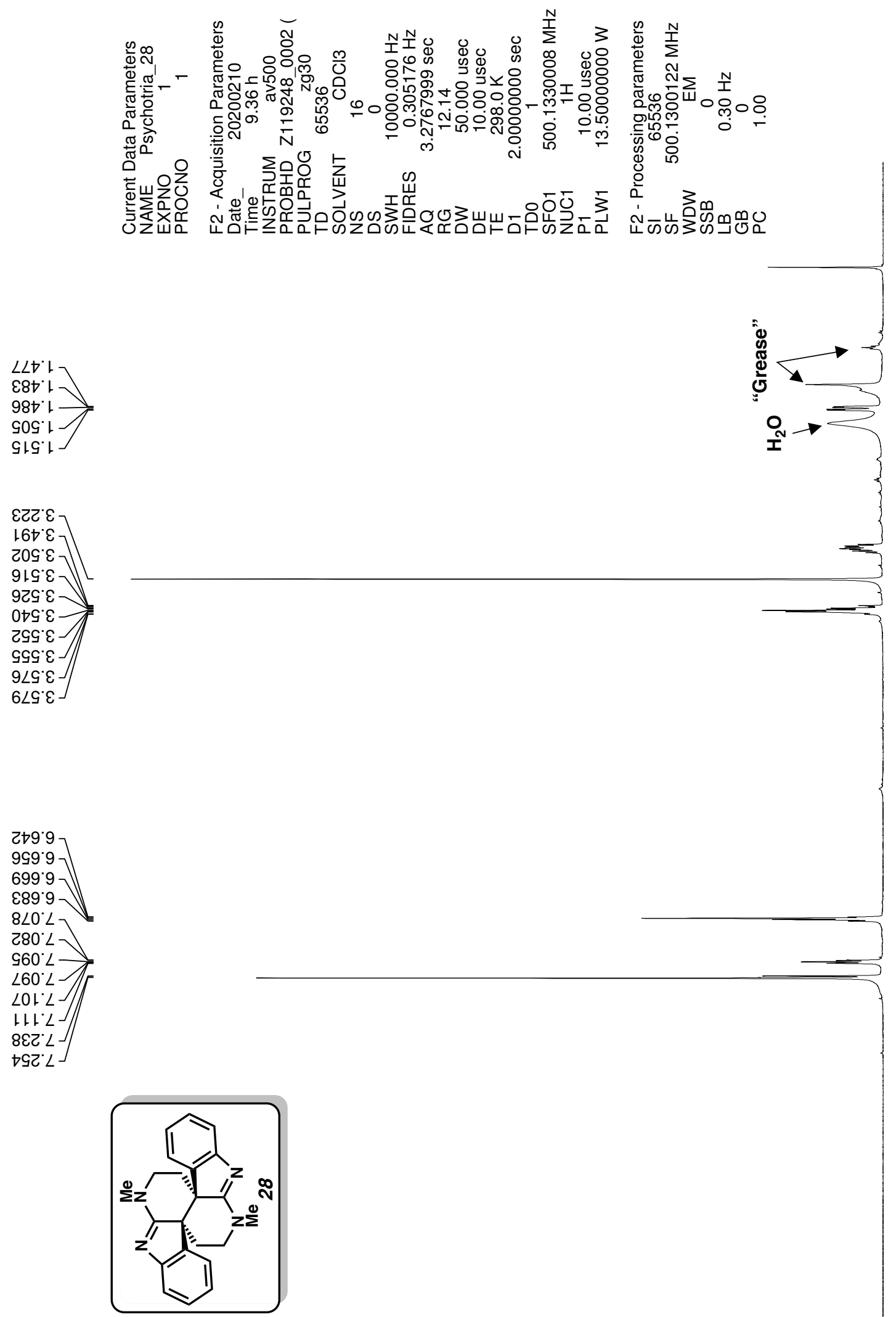
Dotson et al.: Crystalline Control - Supporting Information - S45

\section{${ }^{13}$ C NMR Spectra:}



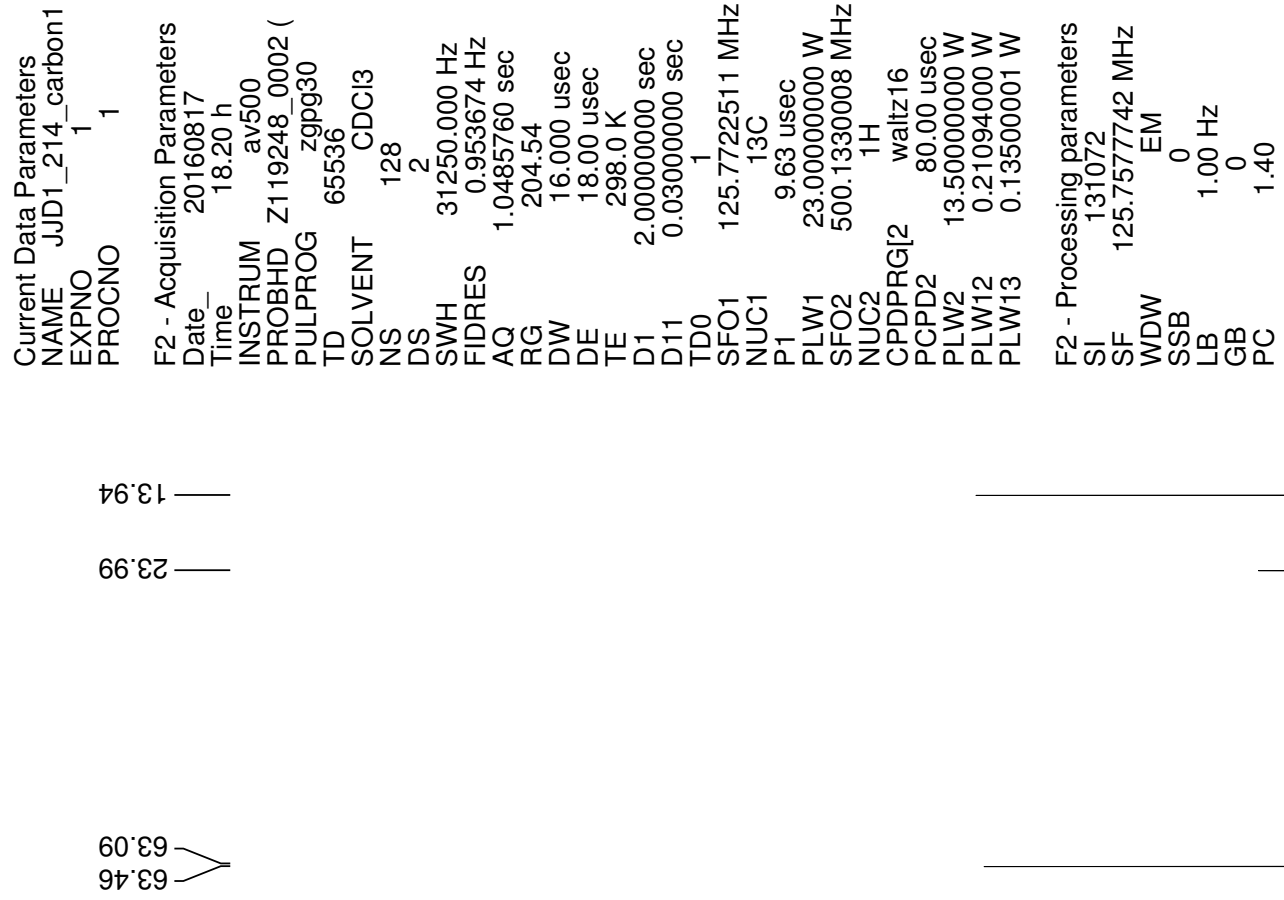

86.9トレ-
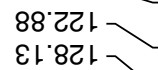

$8 \varepsilon^{\circ} 0 \varepsilon+$

$09.0 \varepsilon 1>$

$86+\varepsilon 1-\top$

$\angle 0^{\circ} \mathrm{SEL}$

$\angle L \cdot \angle 91-$
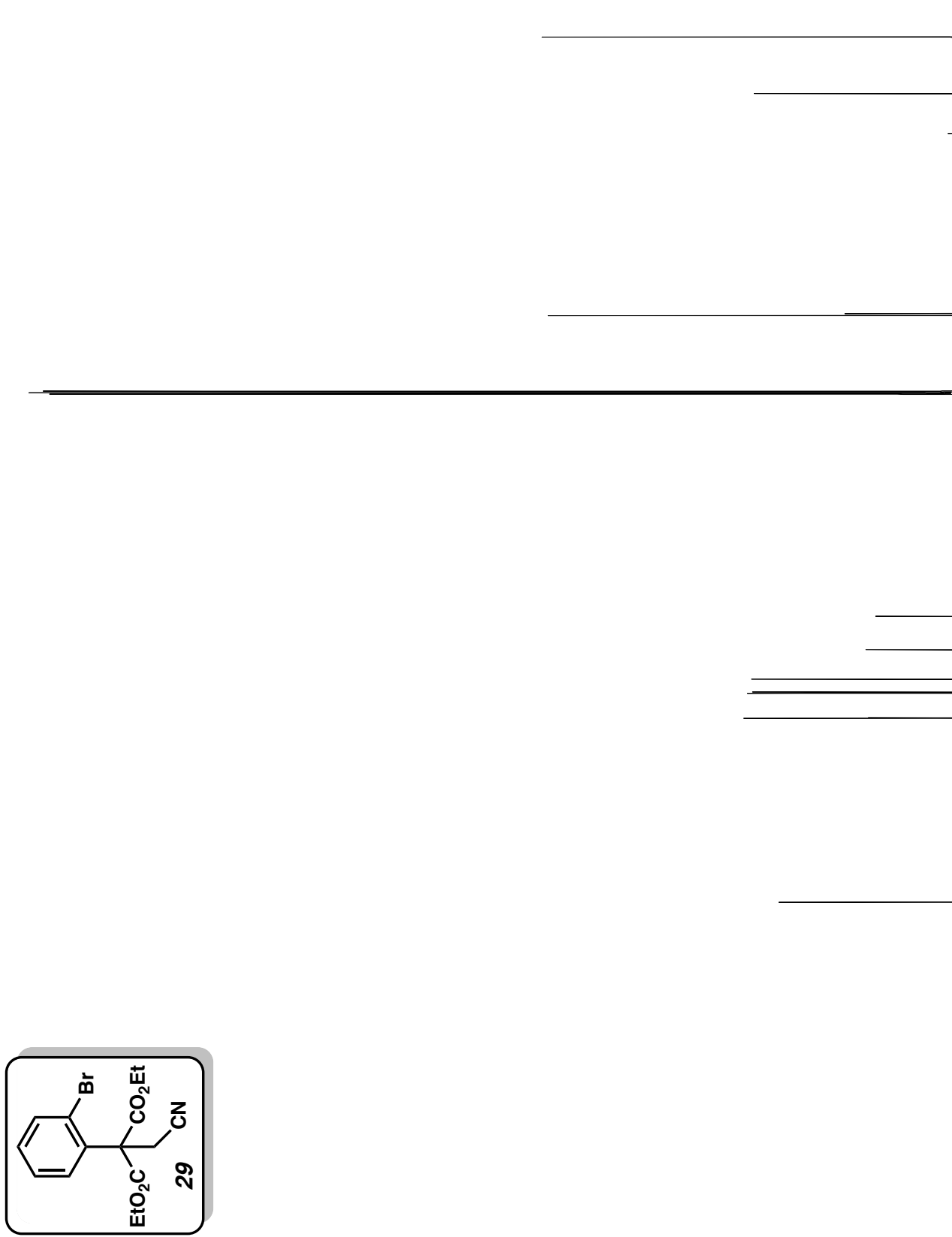

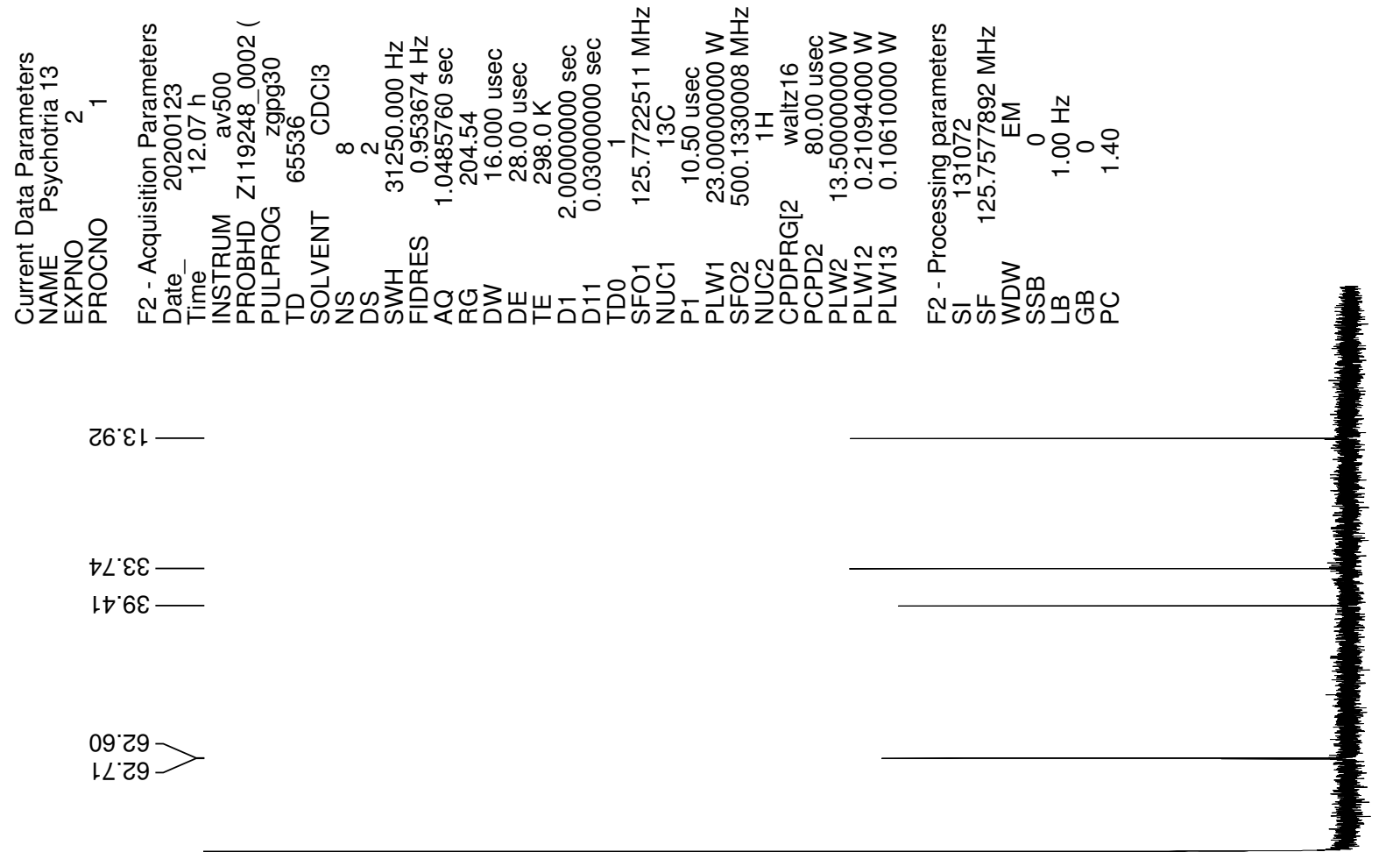

$\angle 6^{\circ} \varepsilon 己$ ᄂ $69^{\circ} \angle 21$

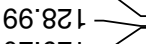

$0 \mathrm{CZ}^{\prime} 6 \mathrm{~L}$

6เ十ลเ

$8 t^{\circ} 8 \varepsilon+$

Sเ: $0 \angle 1-$

$90 \circ \angle 1-$

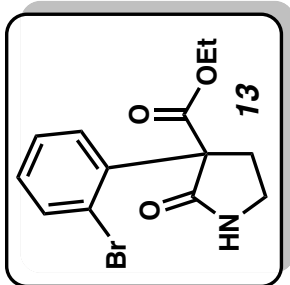



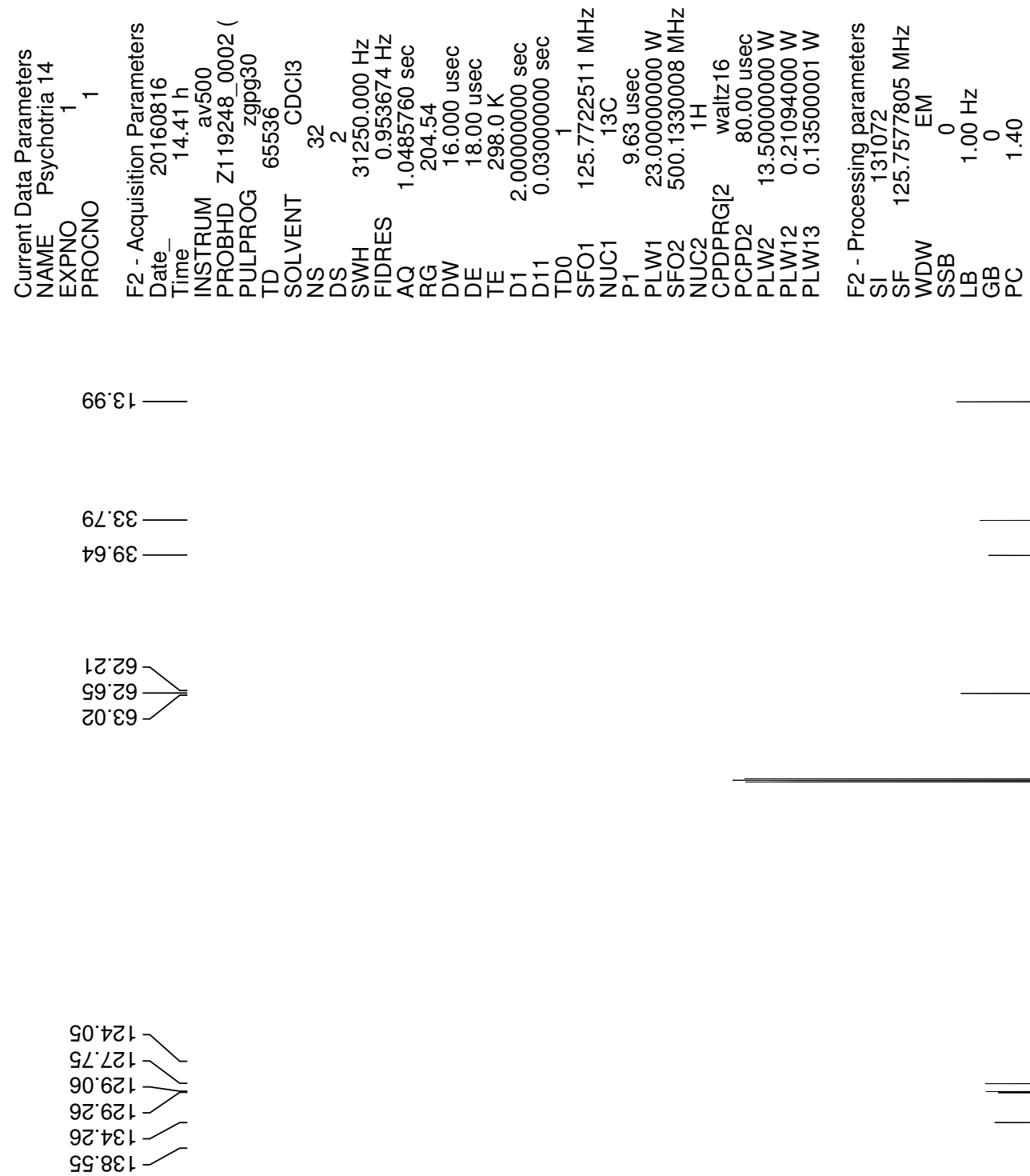

$82^{\circ} 0 \angle L-$
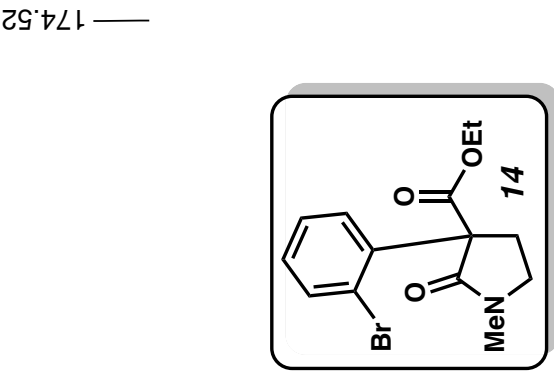

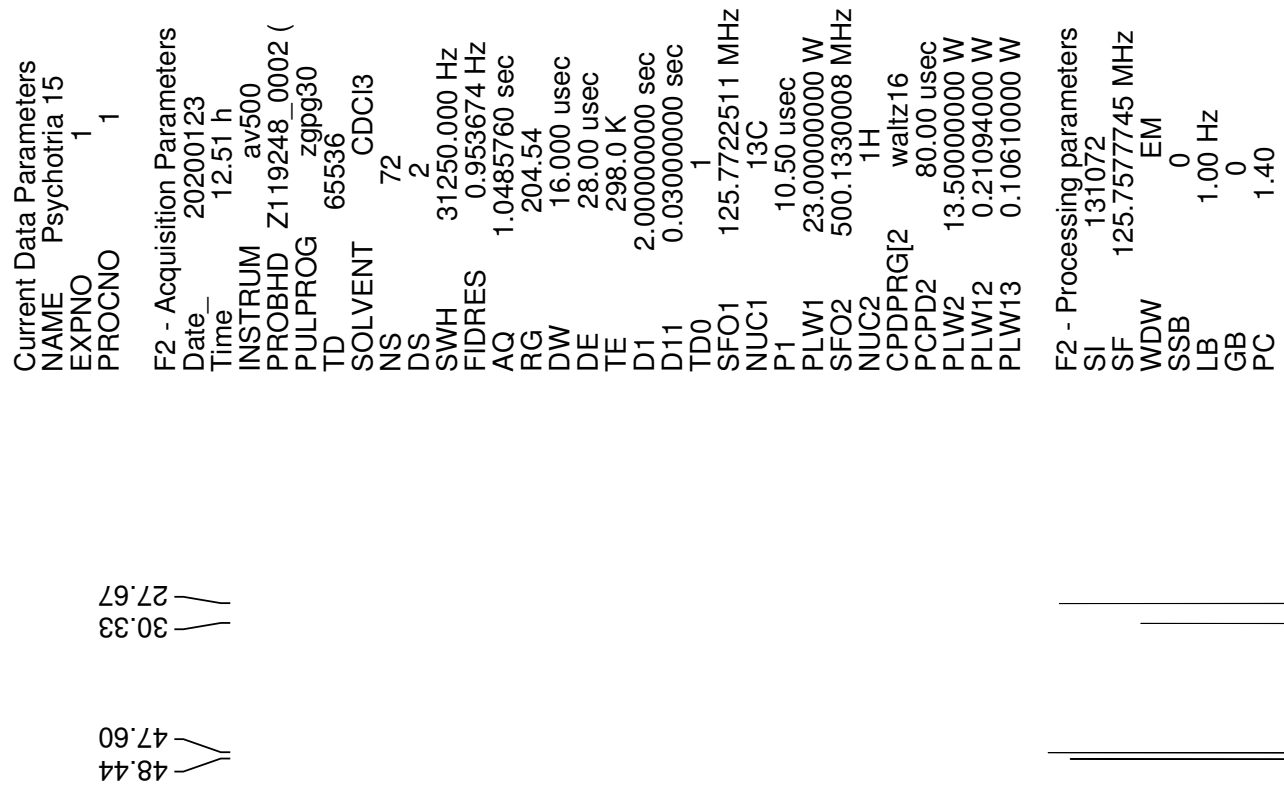

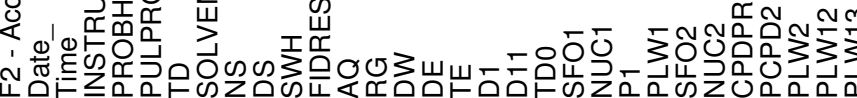

เ0.9ट।

$\angle 0.82$

s9.8Z1

$9 \varepsilon \cdot 6 \mathrm{Ll}$

$90^{\circ} \varepsilon \varepsilon$

$68 \cdot 6 \varepsilon 1-$

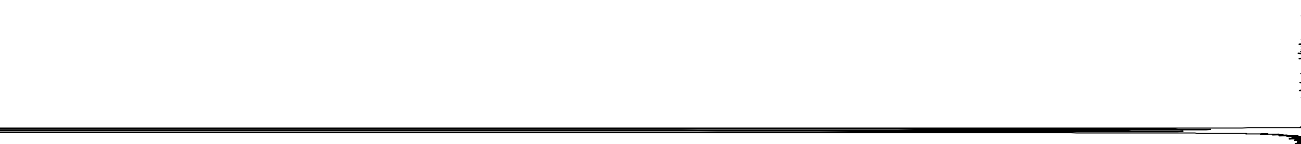

$6 Z^{\prime} \triangleright \angle L$
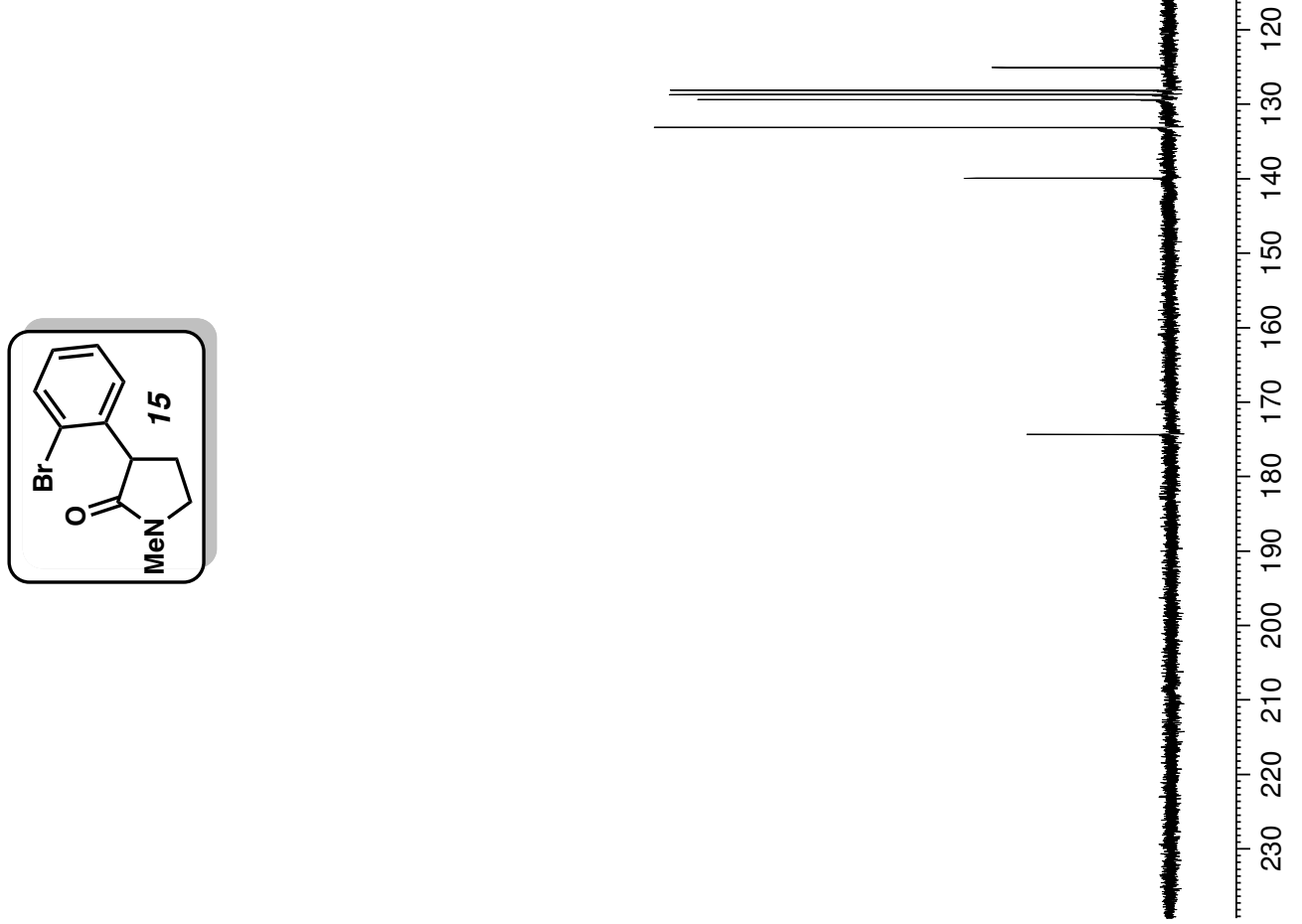


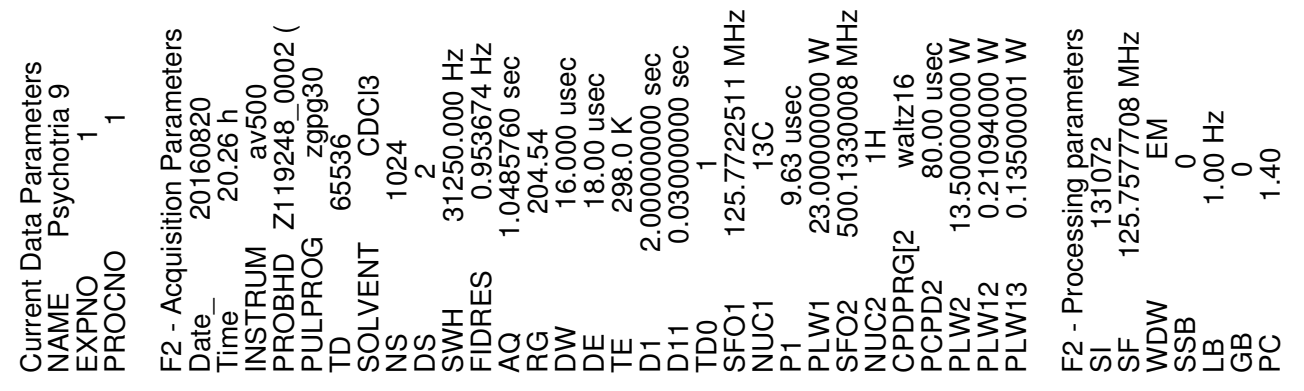

$\angle 8^{\circ} 0 \varepsilon$

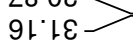

$\downarrow 8 \cdot 9 \triangleright$

SE.0L

$\angle 8^{\circ} \varepsilon 己+$

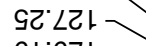

$6 t^{\circ} 6 \mathrm{~L}$

เ乙เEL -

0L $\mathrm{SEL-}$

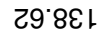

เレLLL

$0 t^{\circ} \angle 6 L$
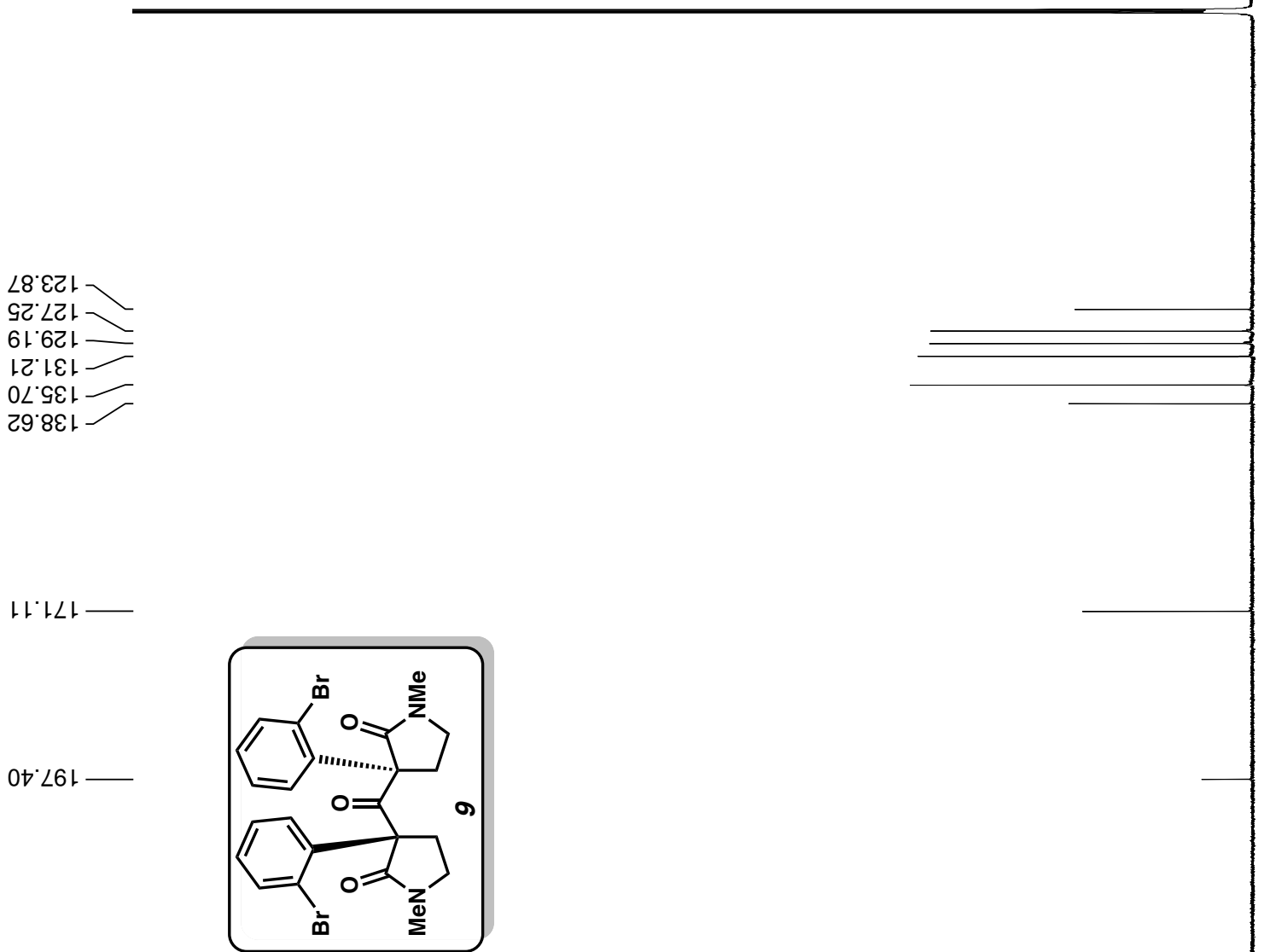

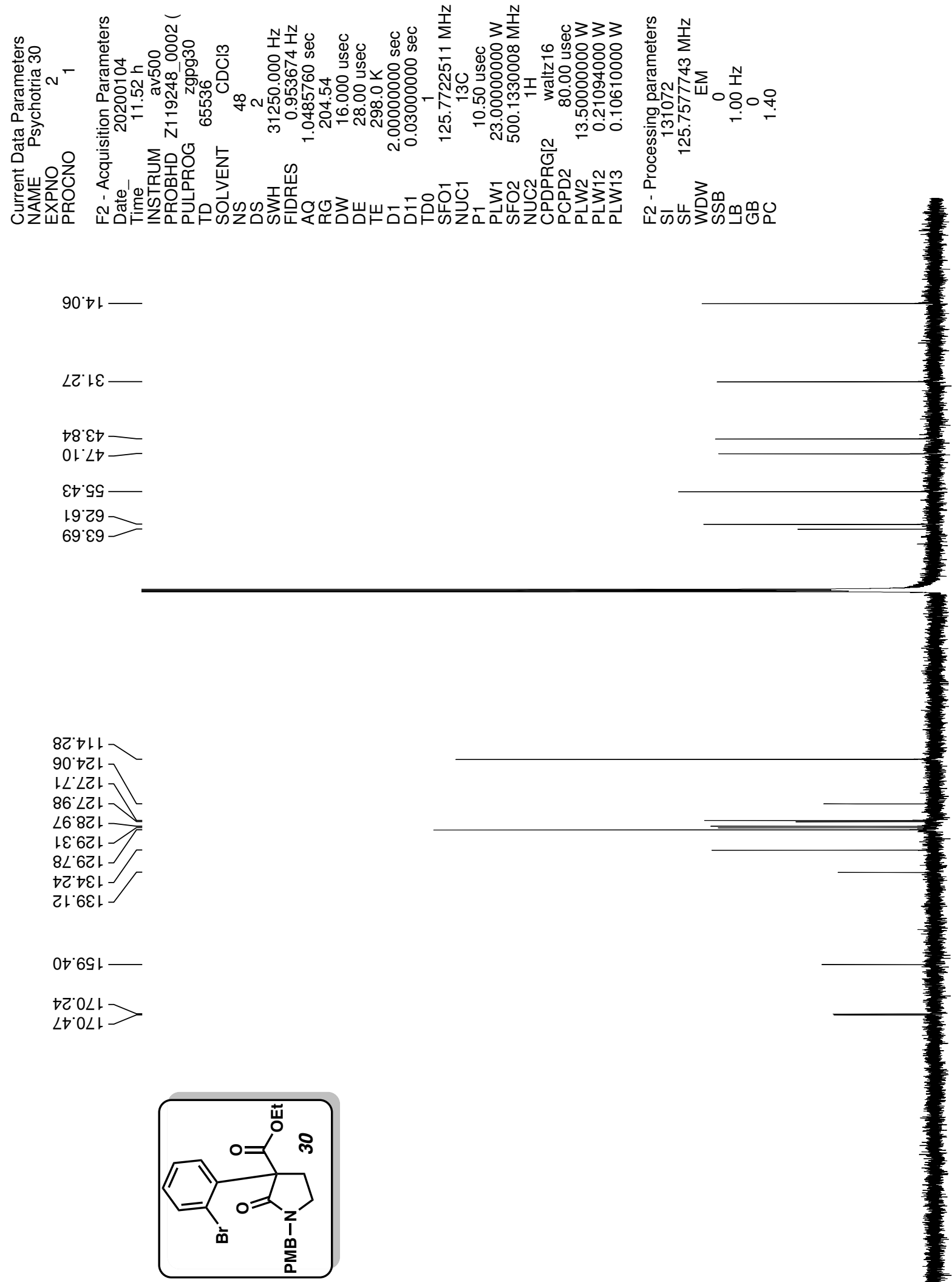

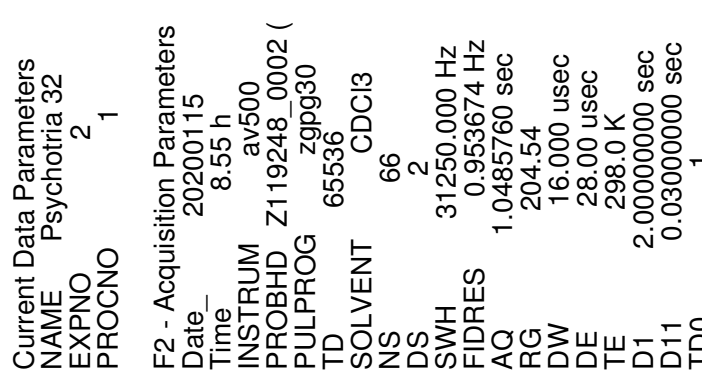

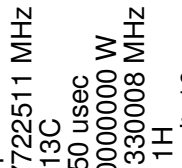
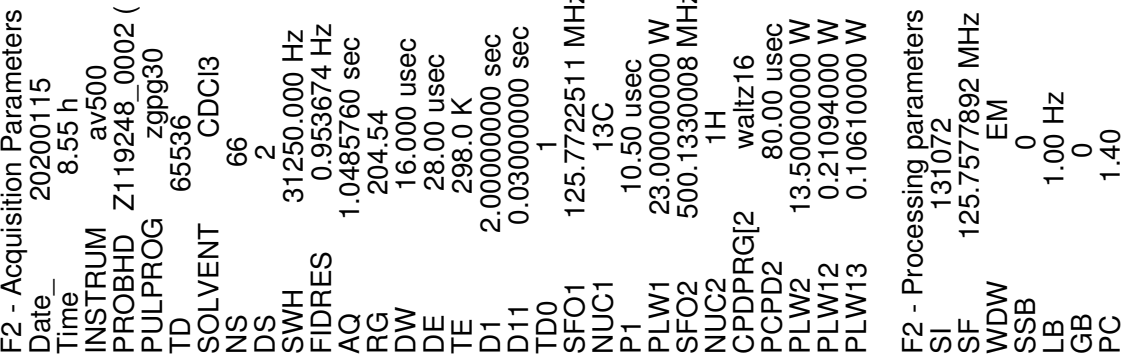

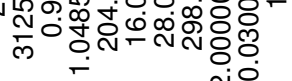

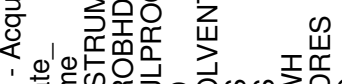

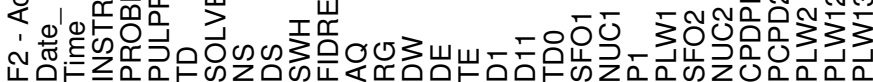

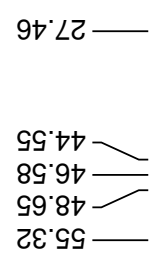

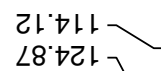
$96^{\circ} \angle 21$

$67^{\circ} 8 \mathrm{~L} 1$

$99 \cdot 8 \mathrm{~L}$

$8 \mathrm{C}^{\circ} 6 \mathrm{~L}$

$0 \angle \cdot 621$

$86 . \mathrm{\cdot L \vdash}$

$\angle 96 \varepsilon+$

$81^{\circ} 69+$

$68^{\cdot} \varepsilon \angle \vdash$

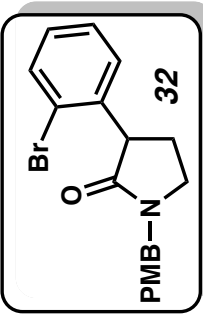



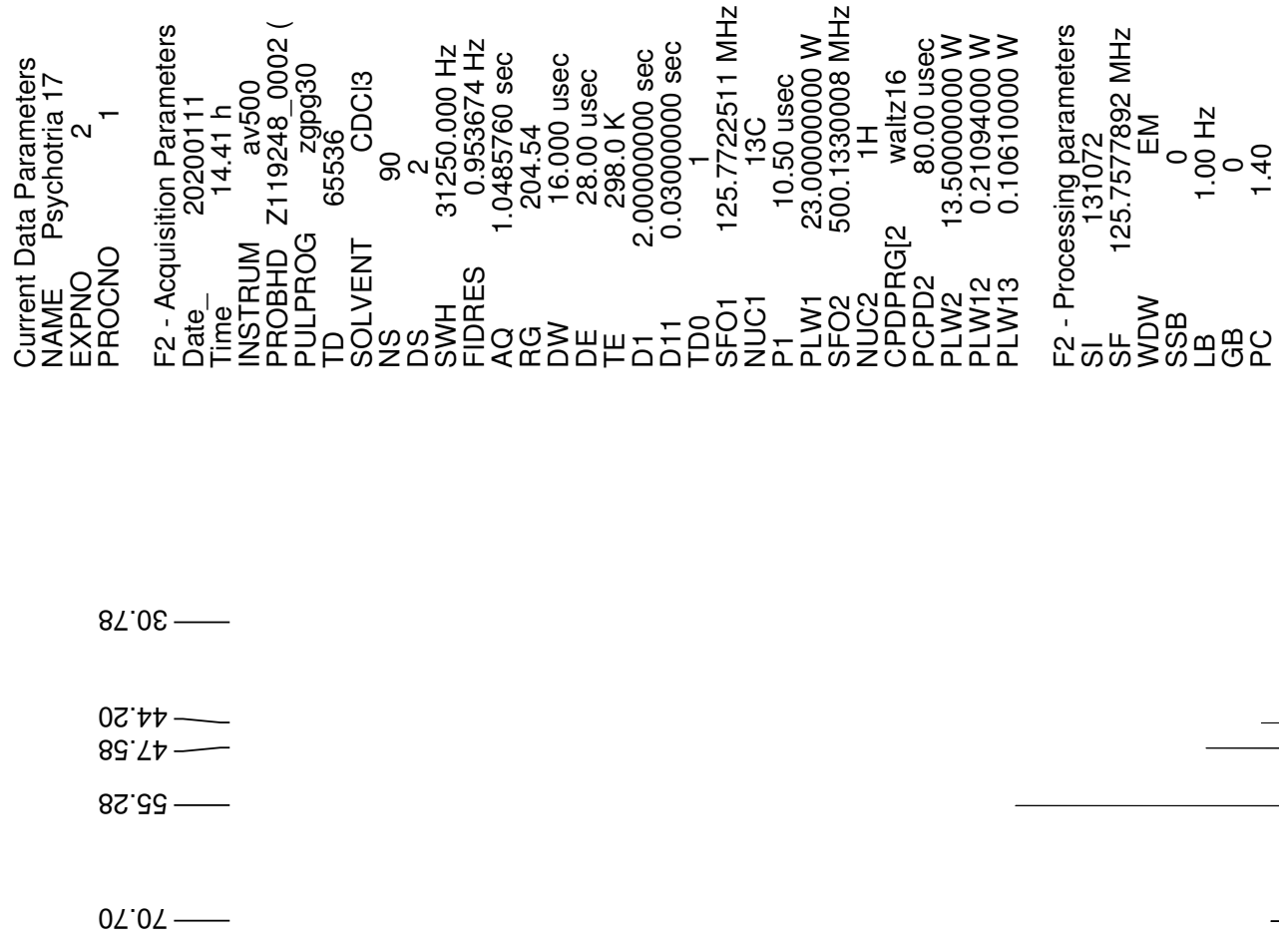

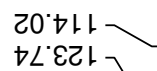
$60 \angle 2 L$ $86^{\circ} \angle Z L$

$\varepsilon+621$

$88.6 \mathrm{~L}$

$0 Z \cdot เ \varepsilon$

†9. $9 \varepsilon$

$0+\cdot 8 \varepsilon+$

OL'6S —

$20 \cdot เ \operatorname{L}$

$20^{\circ} \angle 61-$

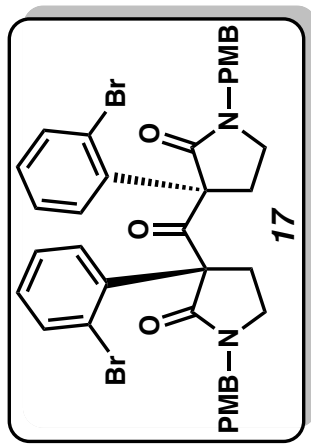




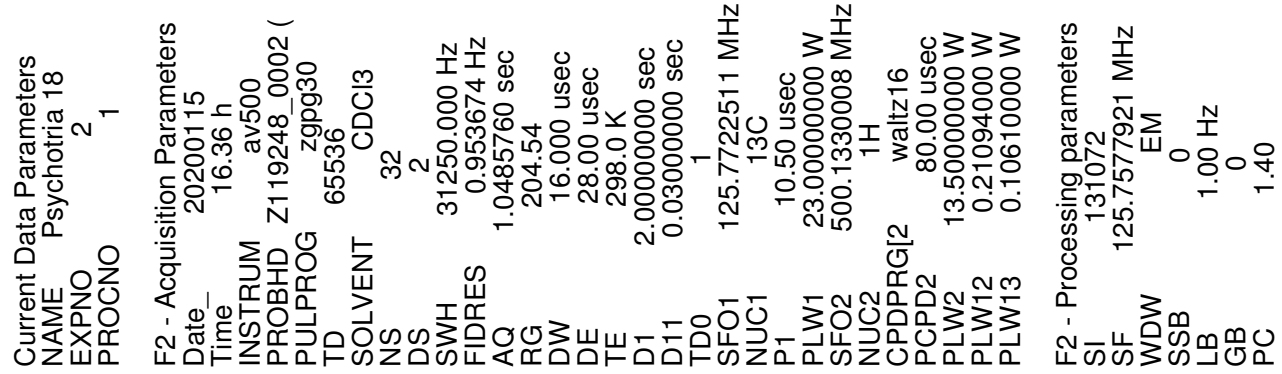

$\varepsilon 0^{\circ} 0 \varepsilon-$

$\angle 0^{\circ} \mathrm{St}$

S๐`S -

SO'ZL

0乙とレー ๑ย.

$06 . \mathrm{sL}$

$\nabla C^{\circ} \angle Z$ L

98.621

$96^{\circ} 0 \varepsilon+$

GL.เEL

99.9Eเ

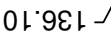

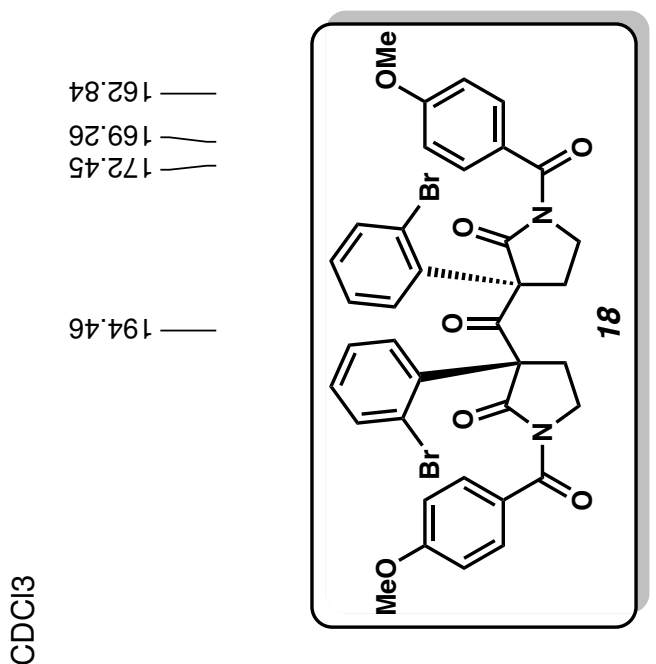



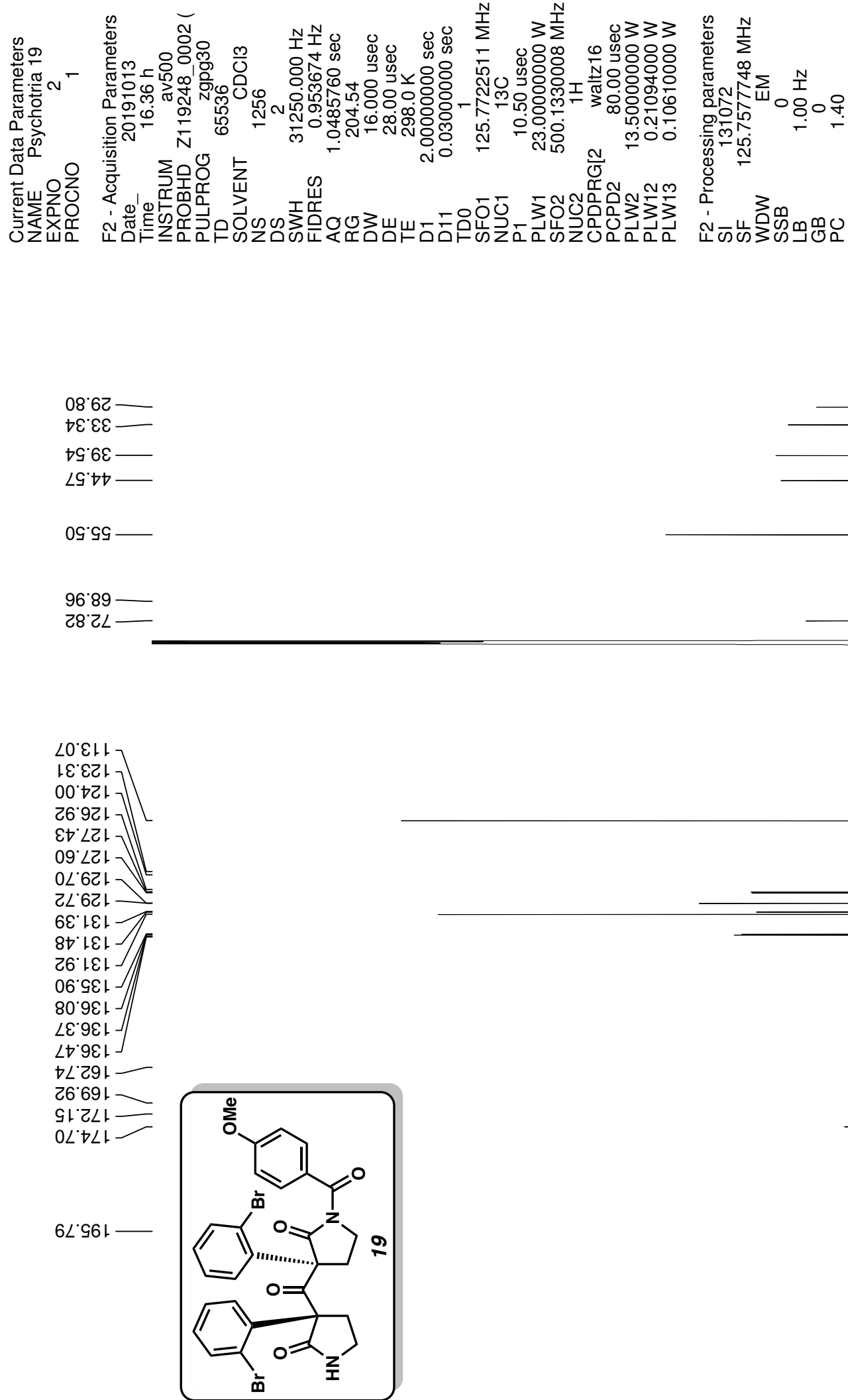

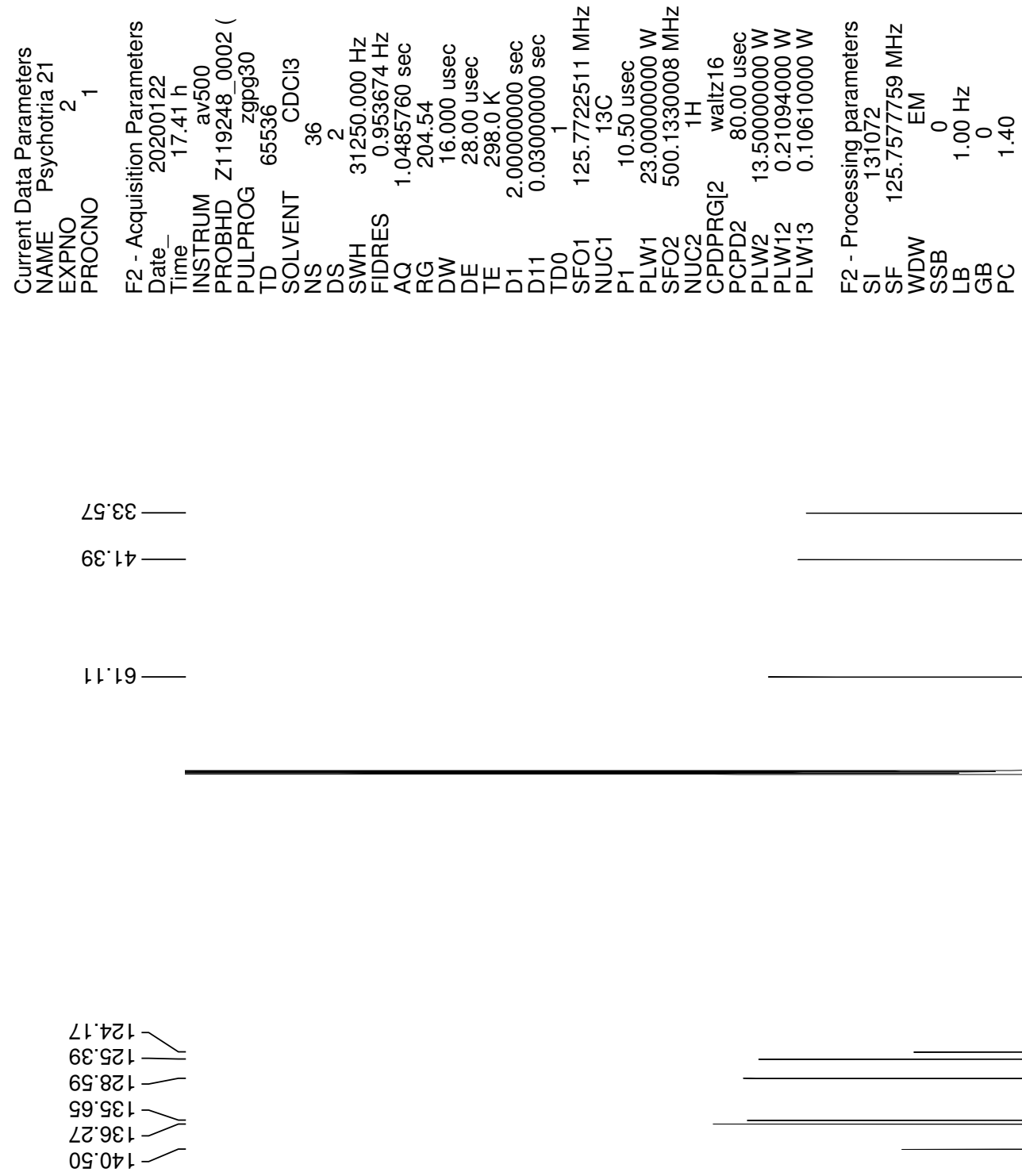

$\angle L \cdot 8 \angle L-$
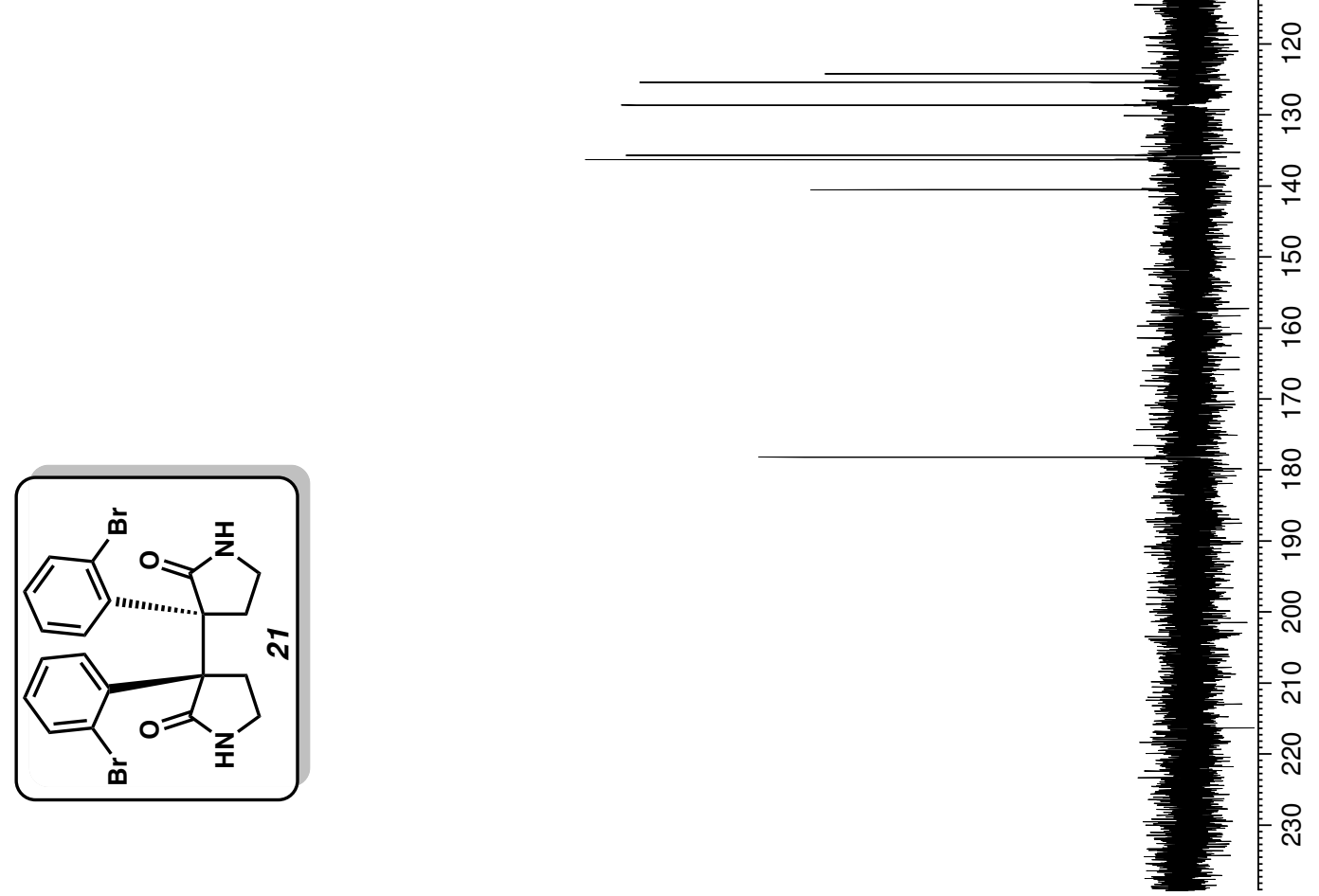

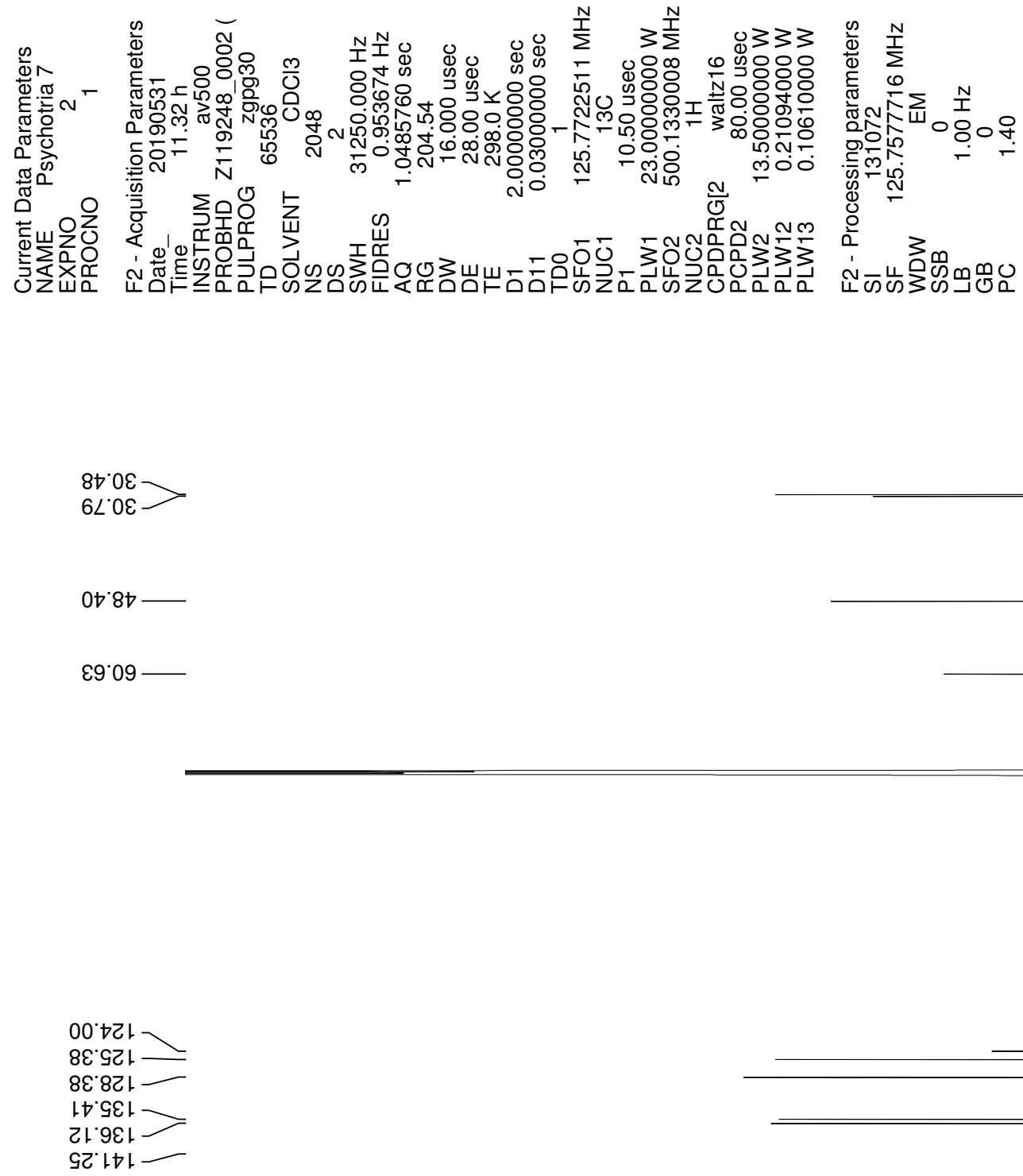

$\angle \vdash E L$

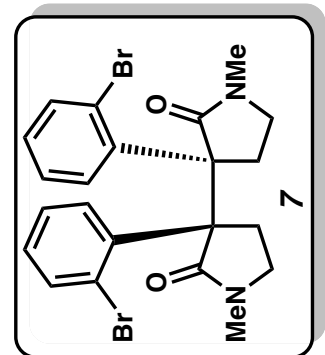



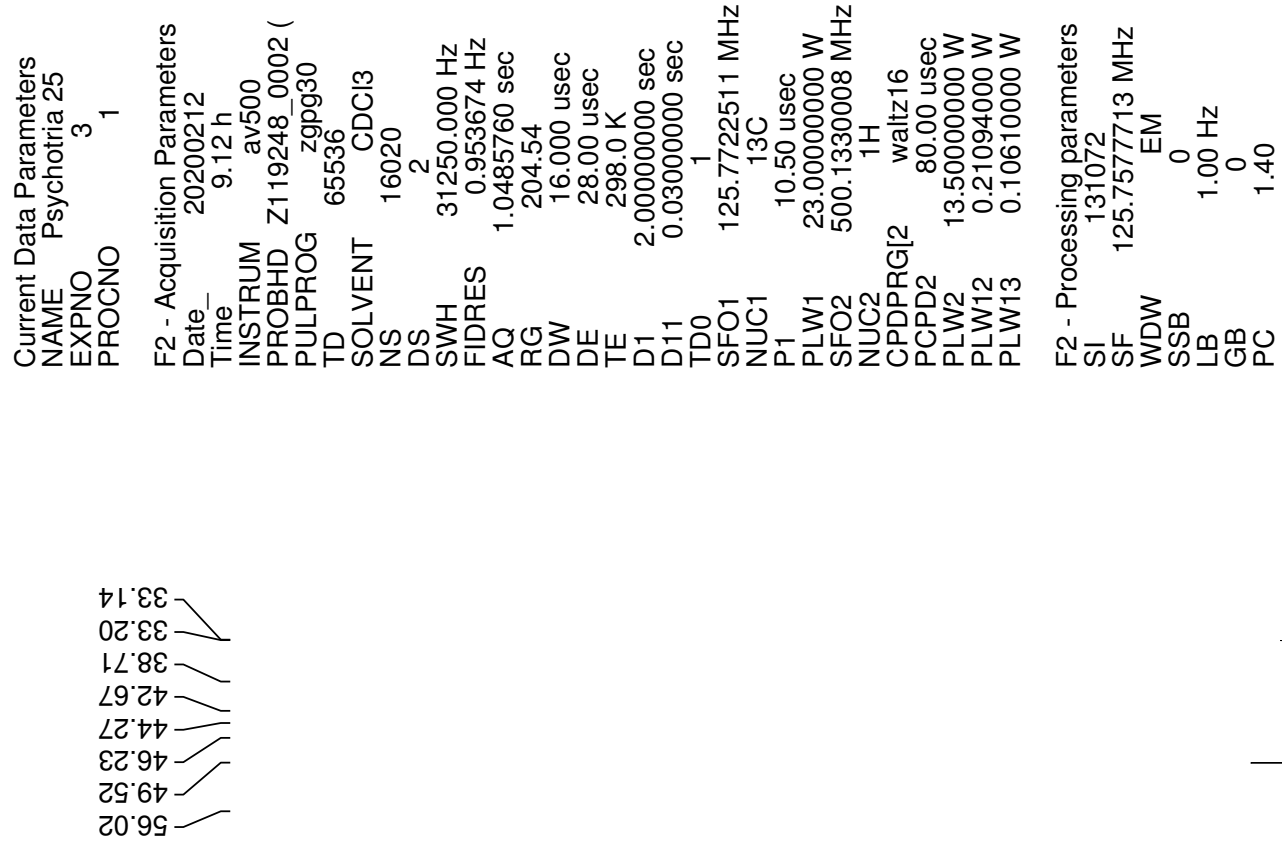

เレ・98

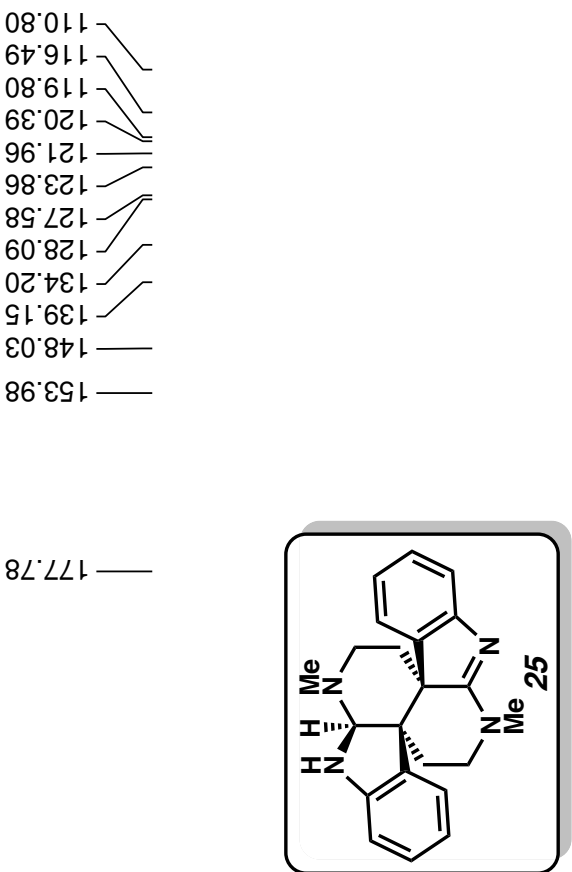

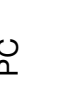



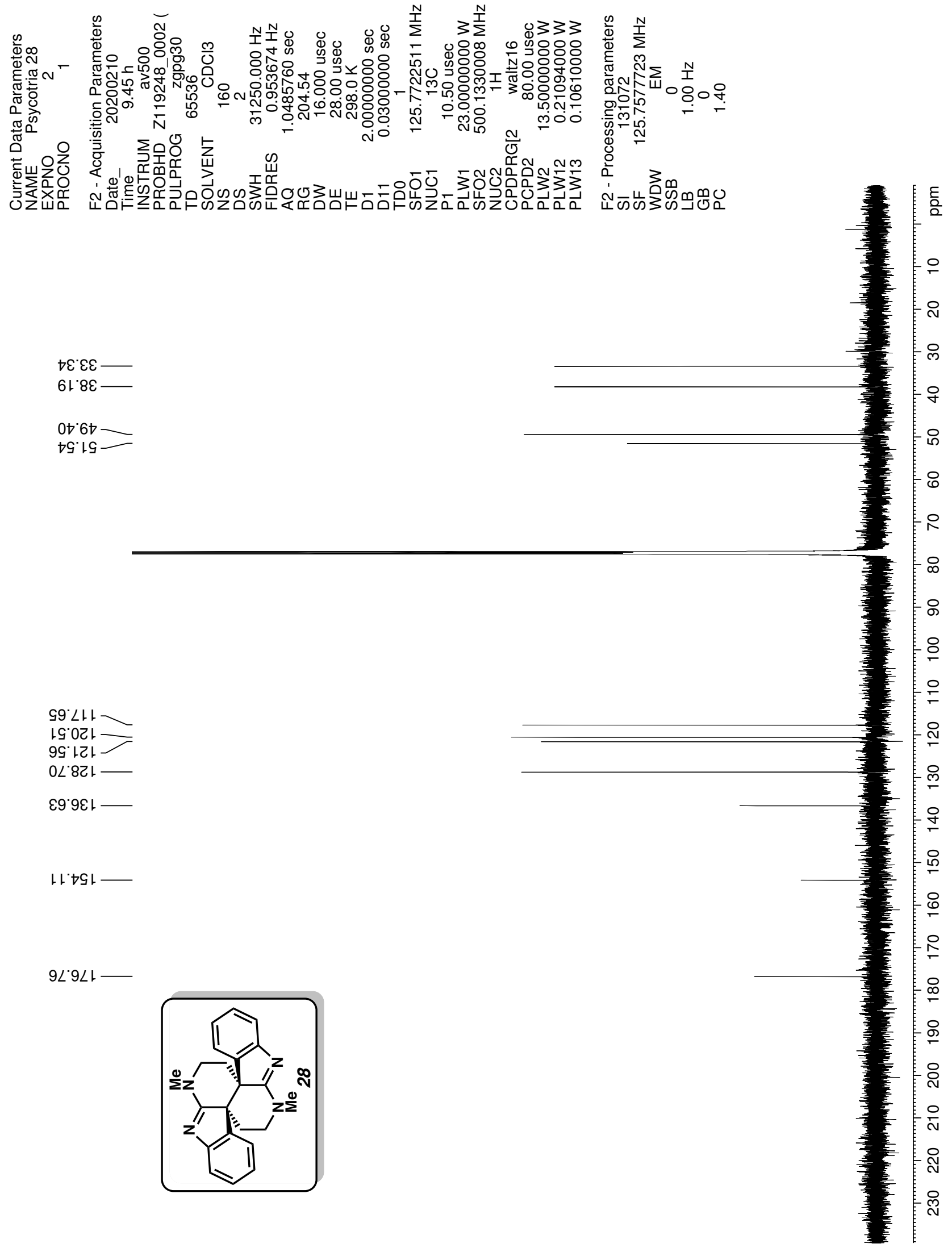


\section{Alternative Routes Explored}

\section{Amine Installation Prior to Photodecarbonylation (Figure S1):}

Having accessed compound $\mathbf{9}$, we were interested in the possibility of carrying out $\mathrm{C}-\mathrm{N}$ bond formation prior to the key photodecarbonylation step. To accomplish this, we subjected 9 to $\mathrm{Cu}$-catalyzed azidation conditions and were delighted to find that 9 underwent double azidation to give 33 in $72 \%$ yield. Next, we attempted reduction of $\mathbf{3 3}$ using hydrogenolysis conditions. However, rather than the desired bis(amine) $\mathbf{3 4}$ for use in photodecarbonylation, we obtained spirocycle 36, presumably via the intermediacy of 34. We also attempted photodecarbonylation of bis(azide) 33 (not shown), which unfortunately led to substantial nonspecific decomposition. The results obtained from these studies led us to realize the requisite order of operations for access to the bis(cyclotryptamine) scaffolds: photodecarbonylation of a ketone bearing a modifiable orthosubstituent followed by installation of the amine moiety.

\section{Figure S1.}
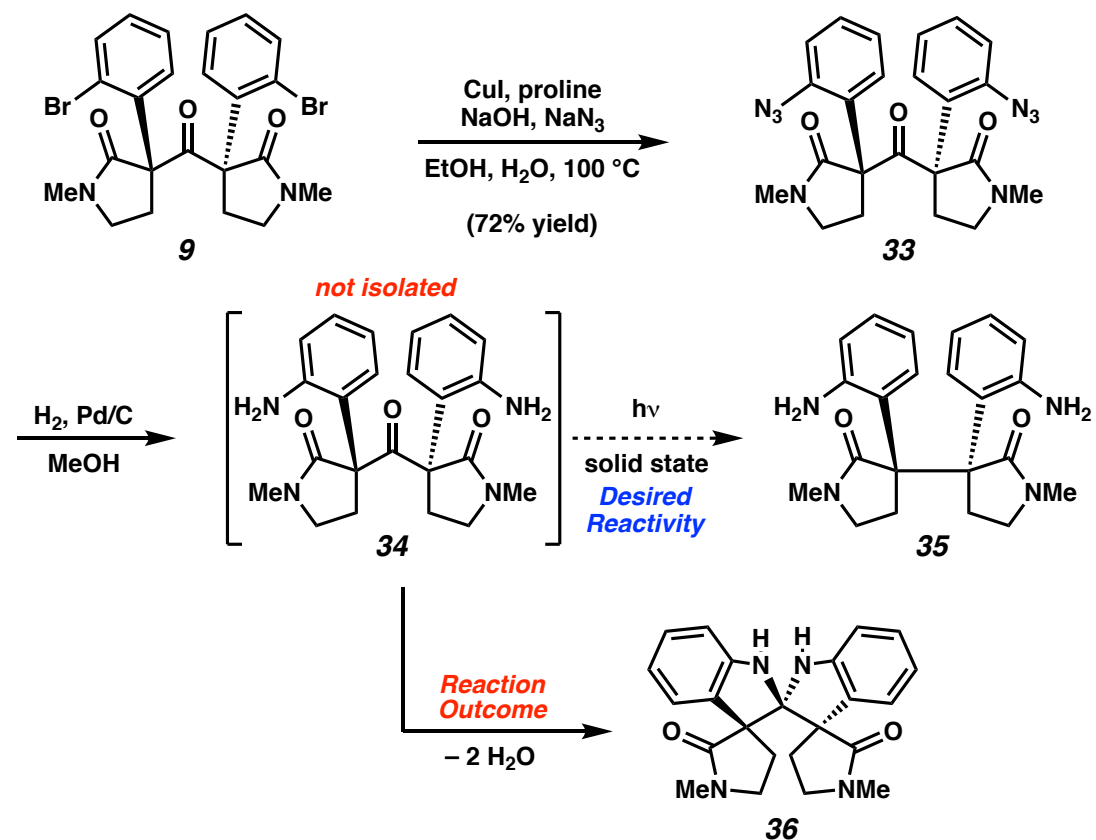

\section{Use of directed ortho- metallation / amination to install requisite amine functional groups (Figure S2):}

Given difficulties faced carrying ortho- substituents on the ketone substrate's aryl groups through the photodecarbonylation reaction, we sought to install the amine substituents through a late stage $\mathrm{C}-\mathrm{H}$ activation of $\mathbf{3 8}$ (Figure $\mathrm{S} 2$ ). Compound $\mathbf{3 8}$ was accessed in $51 \%$ yield by exposing ketone 37 to ultraviolet light in the solid-state. We then attempted to introduce the orthofunctionality through an array of directed metalation / amination sequences. Experts in $\mathrm{C}-\mathrm{H}$ functionalization also tried to achieve this transformation with material provided by our laboratories (using non-disclosed reaction conditions). Unfortunately, despite significant attempts, 
directed lithiation, transition metal-catalyzed functionalization, and nitration routes were uniformly deemed unsuccessful.

\section{Figure S2.}
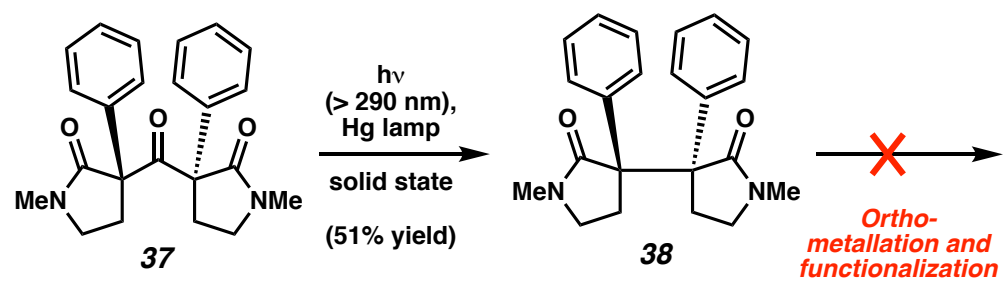

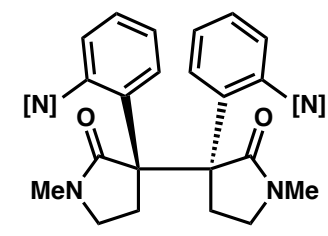

39

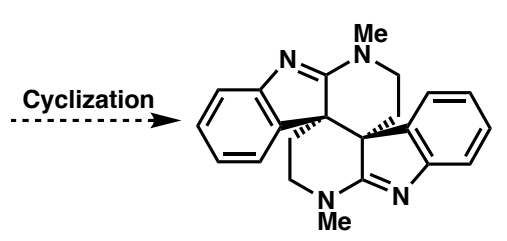

"Psychotriadine" (28)

\section{Use of ortho-chloro substituent to access bis(cyclotryptamines) (Figure S3):}

We investigated using unsymmetrical, chlorinated ketone $\mathbf{4 0}$ to synthesize the bis(cyclotryptamine) alkaloids. Relative to the ortho-bromo substrate 19, chloro-substituted compound 40 was more efficient in the photodecarbonylation reaction, proceeding in $61 \%$ yield over 2 steps to give 41 (compared with $41 \%$ yield for compound 19 to give 21). Amide methylation of 41 proceeded cleanly to give $\mathbf{4 2}$. However, all efforts to achieve activation of the $\mathrm{C}-\mathrm{Cl}$ bond to generate 43 proved unsuccessful. Various catalysts and nucleophiles were investigated, but successful installation of nitrogen atoms from 42 was never realized. 


\section{Figure S3.}<smiles>COc1ccc(C(=O)N2CC[C@H](C(=O)C3(C(=O)c4ccccc4Cl)CCNC3=O)C2=O)cc1</smiles>
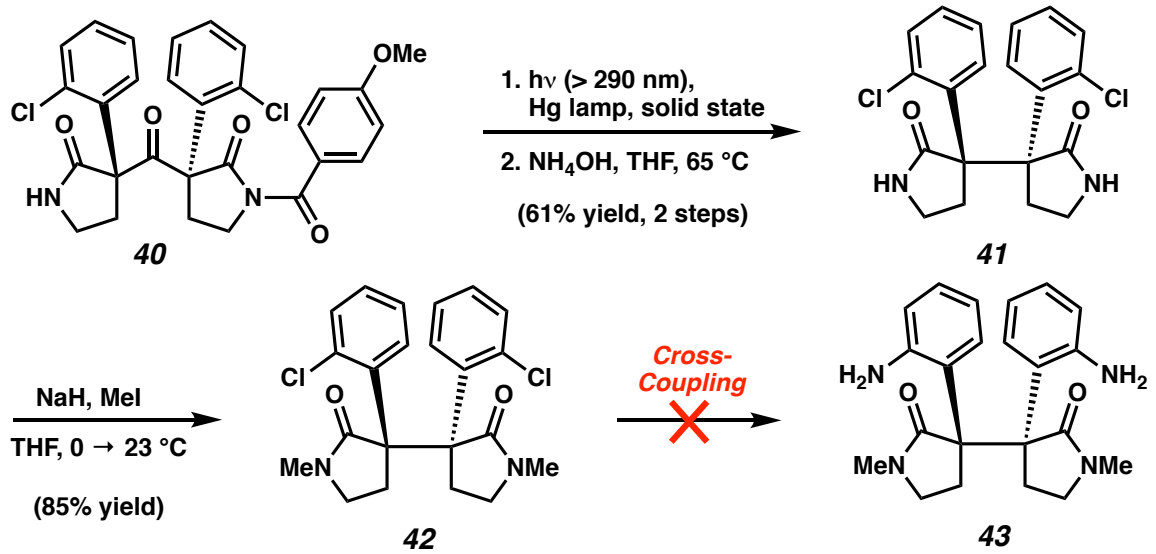

Reduction of dihydropsychotriadine (25) to access other members of the bis(cyclotryptamine) alkaloid family (Figure S4):

We were curious if $\mathbf{2 5}$ could be reduced to $\mathbf{4 4}$. This would help us ascertain if $\mathbf{4 4}$ itself was a stable compound and if it could be isomerized to the alkaloids calycanthine (45) and chimonanthine (46). Unfortunately, attempts to reduce 25 to the corresponding geminal diamine 44 or an isomer thereof were either met with decomposition or led to recovered starting material.

\section{Figure S4.}
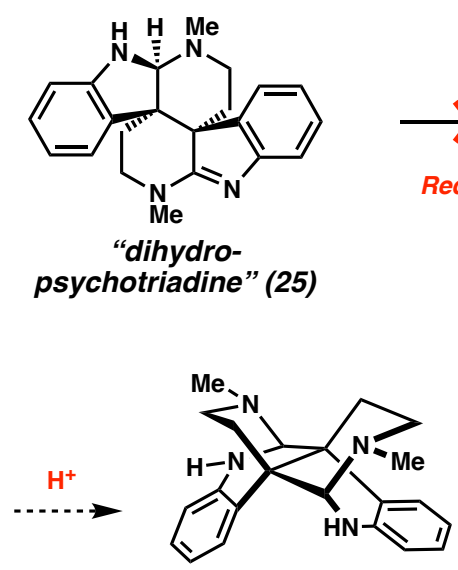

(土)-Calycanthine (45)
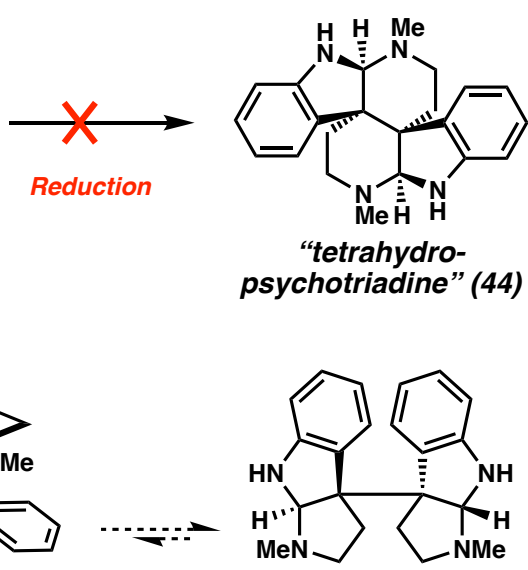

(士)-Chimonanthine (46) 


\section{Alternative Mechanism for the Conversion of 22 to 25}

Although Scheme 3 provides one mechanistic possibility for the conversion of $\mathbf{2 2}$ to $\mathbf{2 5}$, other mechanistic possibilities are feasible. One reasonable mechanism is shown in Figure S5. After reduction of the azide moieties in 22, intermediate 23 could undergo intramolecular condensation to form the five membered amidine 47. Upon reduction with another equivalent of $\mathrm{LiAlH}_{4}, 48$ could rearrange to provide indolenine 49. In turn, 49 could undergo a transamidation to give piperidinone 50, which could give rise to $\mathbf{2 5}$ upon cyclization, dehydration, and aqueous workup.

\section{Figure S5.}

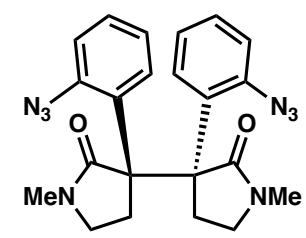

22

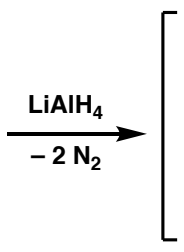

47

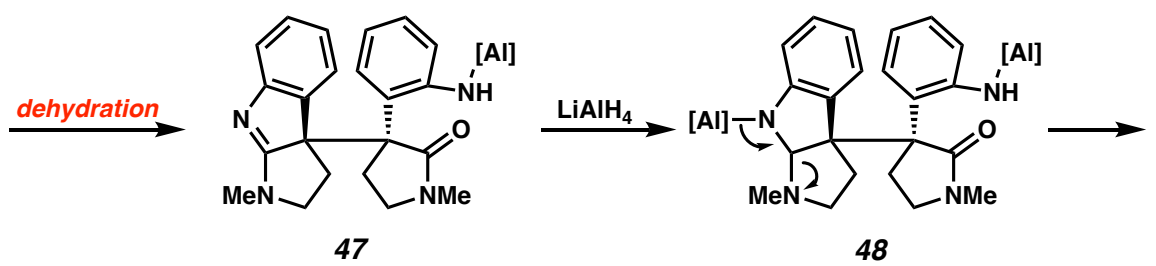<smiles>CCCCCNc1ccccc1C[C@]1(c2ccccc2NC(C)C)CCN(C)C1=O</smiles>

23

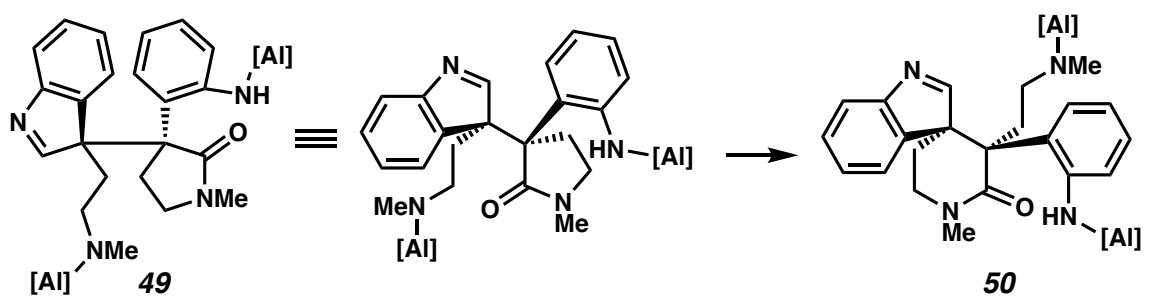<smiles>CCCCN1c2ccccc2[C@]23CCN(C)N4CC[C@@]25C(=Nc2ccccc25)N(C)CC[C@]143</smiles>

51

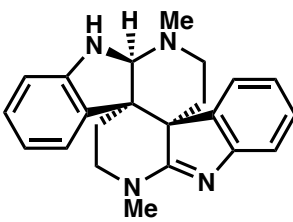

"dihydropsychotriadine” (25) 


\section{X-Ray Crystal Structure Data}
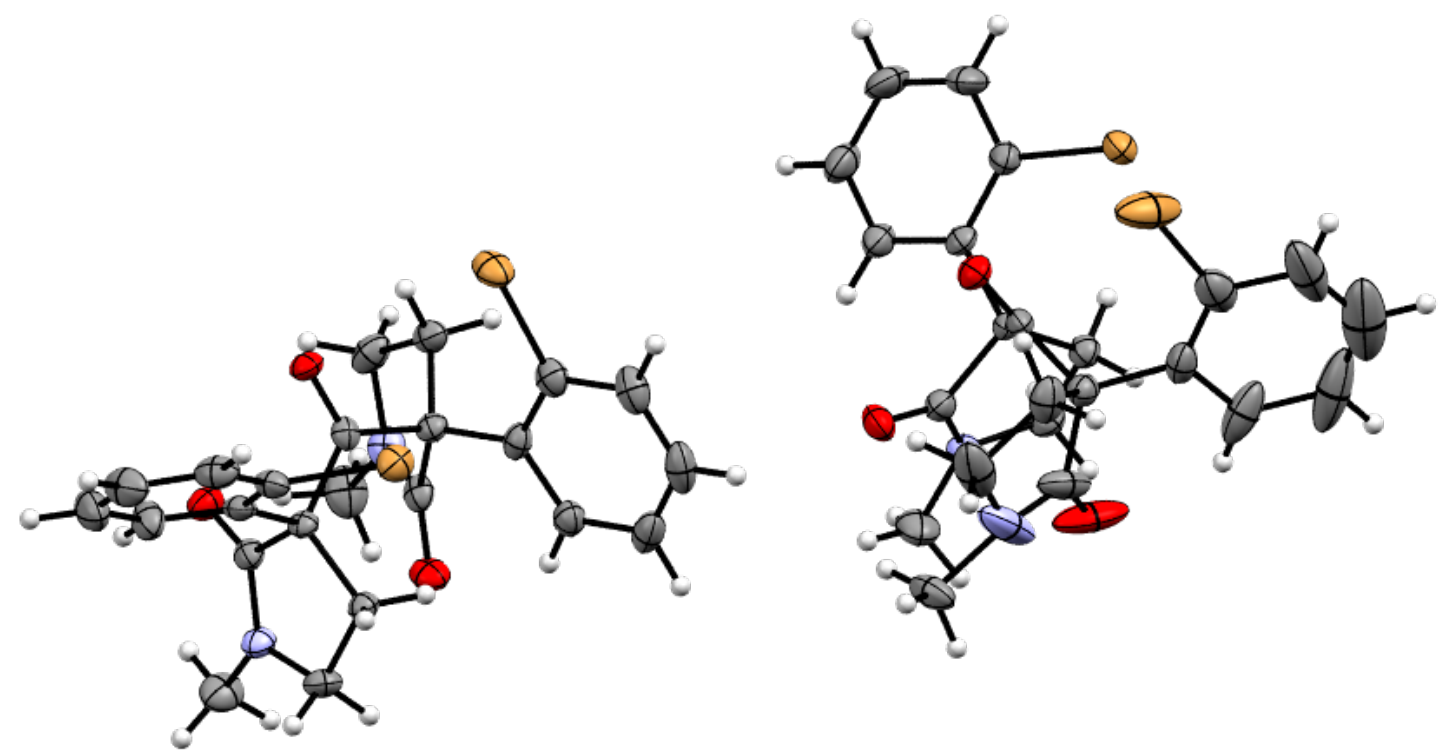

Table S1. Crystal data and structure refinement for 9.

Identification code

Empirical formula

Formula weight

Temperature

Wavelength

Crystal system

Space group

Unit cell dimensions

Volume

Z

Density (calculated)

Absorption coefficient

$\mathrm{F}(000)$

Crystal size

Theta range for data collection

Index ranges

Reflections collected

Independent reflections cu_gg1622-twin5

$\mathrm{C} 23 \mathrm{H} 22 \mathrm{Br} 2 \mathrm{~N} 2 \mathrm{O} 3$

534.24

100(2) K

$1.54178 \AA$

Triclinic

P -1

$\mathrm{a}=8.2766(3) \AA$

$\mathrm{a}=91.499(2)^{\circ}$.

$\mathrm{b}=12.5596(4) \AA$

$\mathrm{b}=95.714(2)^{\circ}$.

$\mathrm{c}=21.0814(7) \AA$

$\mathrm{g}=93.240(2)^{\circ}$.

2175.94(13) $\AA^{3}$

4

$1.631 \mathrm{Mg} / \mathrm{m}^{3}$

$4.952 \mathrm{~mm}^{-1}$

1072

$0.200 \times 0.150 \times 0.100 \mathrm{~mm}^{3}$

2.107 to $69.354^{\circ}$.

$-9<=\mathrm{h}<=9,-15<=\mathrm{k}<=15,0<=\mathrm{l}<=25$

13102

$13102[\mathrm{R}($ int $)=$ ?] 
Completeness to theta $=67.679^{\circ}$

Absorption correction

Max. and min. transmission

Refinement method

Data / restraints / parameters

Goodness-of-fit on $\mathrm{F}^{2}$

Final $\mathrm{R}$ indices [I $>2$ sigma(I)]

$\mathrm{R}$ indices (all data)

Extinction coefficient
$99.3 \%$

Semi-empirical from equivalents

0.75 and 0.49

Full-matrix least-squares on $\mathrm{F}^{2}$

13102 / 60 / 556

1.165

$\mathrm{R} 1=0.0457, \mathrm{wR} 2=0.1275$

$\mathrm{R} 1=0.0597, \mathrm{wR} 2=0.1325$

$\mathrm{n} / \mathrm{a}$

Largest diff. peak and hole 0.946 and -2.055 e. $\AA^{-3}$ 


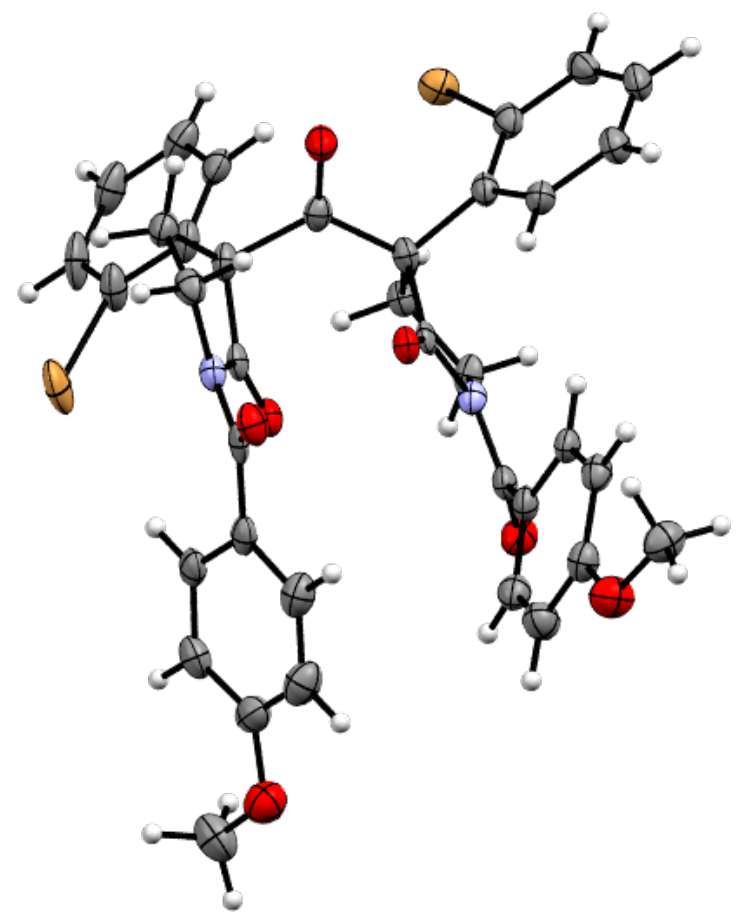

Table S2. Crystal data and structure refinement for $\mathbf{1 8 .}$

Identification code

Empirical formula

Formula weight

Temperature

Wavelength

Crystal system

Space group

Unit cell dimensions

Volume

Z

Density (calculated)

Absorption coefficient

$\mathrm{F}(000)$

Crystal size

Theta range for data collection

Index ranges

Reflections collected cu_gg1916s_a

C37 H30 Br2 N2 O7

774.45

100(2) K

$1.54178 \AA$

Monoclinic

P 21/c

$\mathrm{a}=13.2817(4) \AA \quad \alpha=90^{\circ}$.

$\mathrm{b}=14.6241(4) \AA \quad \beta=90.198(2)^{\circ}$.

$\mathrm{c}=16.4472(4) \AA \quad \gamma=90^{\circ}$.

3194.57(15) $\AA^{3}$

4

$1.610 \mathrm{Mg} / \mathrm{m}^{3}$

$3.684 \mathrm{~mm}^{-1}$

1568

$0.080 \times 0.040 \times 0.020 \mathrm{~mm}^{3}$

3.327 to $70.277^{\circ}$.

$-16<=\mathrm{h}<=16,-17<=\mathrm{k}<=17,-19<=\mathrm{l}<=20$

25105 
Independent reflections

Completeness to theta $=67.679^{\circ}$

Absorption correction

Max. and min. transmission

Refinement method

Data / restraints / parameters

Goodness-of-fit on $\mathrm{F}^{2}$

Final $\mathrm{R}$ indices [I $>2 \operatorname{sigma}(\mathrm{I})]$

$\mathrm{R}$ indices (all data)

Extinction coefficient

Largest diff. peak and hole
$5920[\mathrm{R}(\mathrm{int})=0.0745]$

$99.1 \%$

Semi-empirical from equivalents

0.75 and 0.63

Full-matrix least-squares on $\mathrm{F}^{2}$

$5920 / 0 / 435$

1.026

$\mathrm{R} 1=0.0475, \mathrm{wR} 2=0.1085$

$\mathrm{R} 1=0.0714, \mathrm{wR} 2=0.1199$

$\mathrm{n} / \mathrm{a}$

1.297 and -0.767 e. $\AA^{-3}$ 


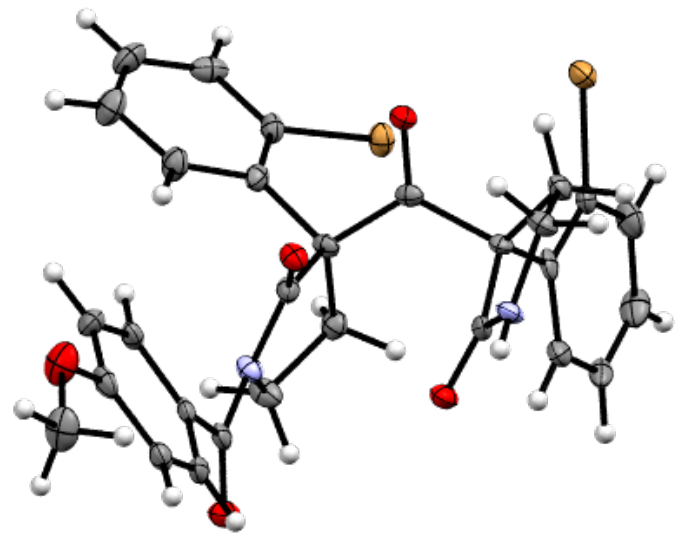

Table S3. Crystal data and structure refinement for 19.

Identification code

Empirical formula

Formula weight

Temperature

Wavelength

Crystal system

Space group

Unit cell dimensions

Volume

Z

Density (calculated)

Absorption coefficient

$\mathrm{F}(000)$

Crystal size

Theta range for data collection

Index ranges

Reflections collected

Independent reflections

Completeness to theta $=67.679^{\circ}$

Absorption correction

Max. and min. transmission

Refinement method

Data / restraints / parameters cu_garg1913s_a

C29 H24 Br2 N2 O5

640.32

100(2) K

$1.54178 \AA$

Monoclinic

P 21/c

$\mathrm{a}=14.9870(5) \AA \quad \alpha=90^{\circ}$.

$\mathrm{b}=10.0874(3) \AA \quad \beta=104.245(2)^{\circ}$.

$\mathrm{c}=17.7928(6) \AA \quad \gamma=90^{\circ}$.

2607.20(15) $\AA^{3}$

4

$1.631 \mathrm{Mg} / \mathrm{m}^{3}$

$4.309 \mathrm{~mm}^{-1}$

1288

$0.180 \times 0.060 \times 0.020 \mathrm{~mm}^{3}$

3.042 to $69.895^{\circ}$.

$-18<=\mathrm{h}<=17,-11<=\mathrm{k}<=12,-20<=\mathrm{l}<=17$

20426

$4685[\mathrm{R}(\mathrm{int})=0.0854]$

$96.1 \%$

Semi-empirical from equivalents

0.75 and 0.60

Full-matrix least-squares on $\mathrm{F}^{2}$

4685 / 0 / 347 
Goodness-of-fit on $\mathrm{F}^{2}$

Final $\mathrm{R}$ indices [I>2sigma(I)]

$\mathrm{R}$ indices (all data)

Extinction coefficient

Largest diff. peak and hole
1.054

$\mathrm{R} 1=0.0437, \mathrm{wR} 2=0.0954$

$\mathrm{R} 1=0.0671, \mathrm{wR} 2=0.1022$

$\mathrm{n} / \mathrm{a}$

0.665 and -0.771 e. $\AA^{-3}$ 

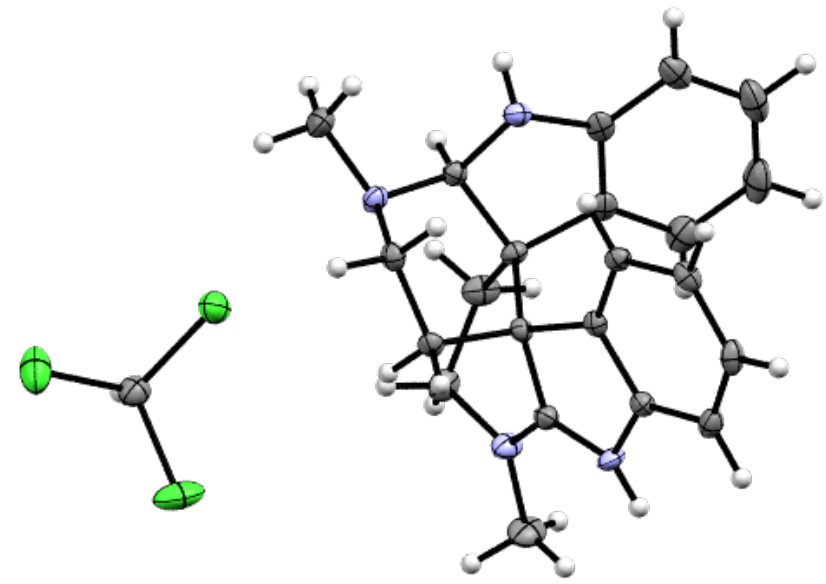

Table S4. Crystal data and structure refinement for 25.

Identification code

Empirical formula

Formula weight

Temperature

Wavelength

Crystal system

Space group

Unit cell dimensions

Volume

Z

Density (calculated)

Absorption coefficient

$\mathrm{F}(000)$

Crystal size

Theta range for data collection

Index ranges

Reflections collected

Independent reflections garg2002s_a

$\mathrm{C} 23 \mathrm{H} 26 \mathrm{Cl} 4 \mathrm{~N} 4$

500.28

$100(2) \mathrm{K}$

$1.54178 \AA$

Triclinic

$\mathrm{P}-1$

$\mathrm{a}=9.6194(4) \AA$

$\alpha=69.962(3)^{\circ}$.

$\mathrm{b}=11.4565(5) \AA$

$\beta=87.308(3)^{\circ}$.

$\mathrm{c}=12.5447(6) \AA$

$\gamma=66.232(2)^{\circ}$.
2

$1.406 \mathrm{Mg} / \mathrm{m}^{3}$

$4.693 \mathrm{~mm}^{-1}$

520

$.20 \times .10 \times .04 \mathrm{~mm}^{3}$

3.772 to $69.534^{\circ}$.

$-11<=\mathrm{h}<=11,-13<=\mathrm{k}<=13,-15<=\mathrm{l}<=14$

16933

$4241[\mathrm{R}(\mathrm{int})=0.0411]$ 
Completeness to theta $=67.679^{\circ}$

Absorption correction

Max. and min. transmission

Refinement method

Data / restraints / parameters

Goodness-of-fit on $\mathrm{F}^{2}$

Final $\mathrm{R}$ indices [I $>2$ sigma(I)]

$\mathrm{R}$ indices (all data)

Extinction coefficient
$96.3 \%$

Semi-empirical from equivalents

0.75 and 0.59

Full-matrix least-squares on $\mathrm{F}^{2}$

4241 / 0 / 290

1.149

$\mathrm{R} 1=0.0327, \mathrm{wR} 2=0.0851$

$\mathrm{R} 1=0.0416, \mathrm{wR} 2=0.0881$

$\mathrm{n} / \mathrm{a}$

Largest diff. peak and hole 0.333 and -0.268 e. $\AA^{-3}$ 


\section{References}

${ }^{1}$ Zhang, D.; Yum, E. K.; Liu, Z.; Larock, R. C. Synthesis of Indenes by the Palladium-Catalyzed Carboannulation of Internal Alkynes. Org. Lett. 2005, 7, 4963-4966.

${ }^{2}$ Armarego, W. L. F.; Chai, C. Purifications of Laboratory Chemicals, $6^{\text {th }}$ ed.; ButterworthHeinemann: Oxford, 2009; p 461.

${ }^{3}$ Verotta, L.; Pilati, T.; Tató, M.; Elisabetsky, E.; Amaor, T. A.; Nunes, D. S. Pyrrolidinoindoline Alkaloids from Psychotria colorata. J. Nat. Prod. 1998, 61, 392-396. 